Szegedi Tudományegyetem

Természettudományi és Informatikai Kar

Fizika Doktori Iskola

\title{
A fémtartalom szerepe a csillagpulzációban
}

$\mathrm{PhD}$ értekezés

\section{Sziládi Katalin}

Témavezetô: Dr. Vinkó József tudományos fômunkatárs MTA CSFK Konkoly Thege Miklós Csillagászati Intézet SZTE Optikai és Kvantumelektronikai Tanszék

Konzulens: Dr. Szabados László kutató professor emeritus MTA CSFK Konkoly Thege Miklós Csillagászati Intézet

Szeged, 2018 


\section{Tartalomjegyzék}

$\begin{array}{ll}\text { 1. Bevezetés } & 3\end{array}$

2. Irodalmi áttekintés $\quad \mathbf{5}$

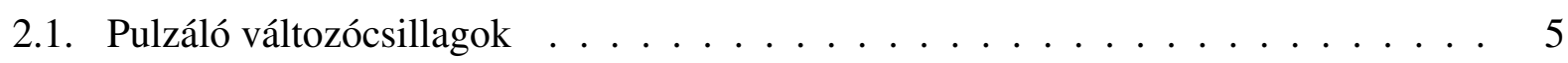

2.1.1. Pulzáló változócsillagok általában . . . . . . . . . . . . . . . 5

2.1.2. Cefeidák . . . . . . . . . . . . . . . . . 9 9

2.1.3. Kétmódusú cefeidák . . . . . . . . . . . . . . . 10

2.2. Pulzációelmélet alapjai . . . . . . . . . . . . . . . . 15

3. Mérési módszerek elméleti alapjai 19

3.1. Fotometria . . . . . . . . . . . . . . . . . . . . 19

3.1.1. Fotometria alapjai . . . . . . . . . . . . . . 19

3.1.2. Fourier-analízis . . . . . . . . . . . . . . 22

3.1.3. OGLE - Optical Gravitational Lensing Experiment . . . . . . . . . . . . 26

3.2. Spektroszkópia . . . . . . . . . . . . . . . . . . . 27

3.2.1. Nagy felbontású echelle-spektroszkópia . . . . . . . . . . . . . . . . . 27

3.2.2. Kémiai analízis . . . . . . . . . . . . . . . . . . . 32

$\begin{array}{ll}\text { 4. Célkitúzések } & 35\end{array}$

5. Mérések és alkalmazott módszerek 36

5.1. Spektrumok redukálása . . . . . . . . . . . . . . . . . 36

5.2. Kémiai analízis kivitelezése . . . . . . . . . . . . . . . . . . 47

5.3. Fémesség meghatározása fotometriai adatokból . . . . . . . . . . . . . . 52

6. Tudományos eredmények $\quad \mathbf{5 4}$

6.1. Kétmódusú cefeidák új, spektroszkópiai $[\mathrm{Fe} / \mathrm{H}]$ értékei . . . . . . . . . . . . 54

6.2. A periódus - periódusarány - fémesség összefüggés . . . . . . . . . . . . . . 62

6.3. Fotometriai fémességek kétmódusú cefeidákra . . . . . . . . . . . . . . 66

$\begin{array}{ll}\text { 7. Összefoglalás } & 74\end{array}$ 
8. Summary

9. Köszönetnyilvánítás

10. Függelék 


\section{1. fejezet}

\section{Bevezetés}

Asztrofizikai és kozmológiai szempontból a klasszikus cefeidák nagyon fontos objektumoknak számítanak. Asztrofizikában a radiálisan pulzáló csillagok atmoszférájának és evolúciójának megismerését segítik, míg a kozmológiában távolságmérô objektumoknak használjuk ôket. A klasszikus cefeidák egy szúkebb csoportját alkotják az egyszerre két rezgési módusban pulzáló kétmódusú vagy beat cefeidák. Ezen csillagok pulzációjának modellezése már az 1990-es években elkezdődőtt, amelynek során fény derült arra, hogy a pulzációs periódusok aránya $\left(P_{1} / P_{0}\right)$ szorosan összefügg a csillag egyéb fizikai paramétereivel, például az effektív hőmérséklettel, tömeggel, luminozitással és a fémtartalommal. Az elméleti modellek helyességének ellenôrzésére sokáig nem volt lehetôség, hiszen ehhez modern megfigyelő múszerekre volt szükség.

2004-ben méréseket végeztünk a nagy felbontású FEROS echelle-spekrográffal, amely az ESO chilei La Silla Obszervatóriumának 2,2 méteres távcsövére volt felszerelve. A mérés eredményeként a 23 ismert déli beat cefeidából 17 csillagról készítettünk spektrumokat, amelyekből 4-et korábban csak fotometriai módszerekkel vizsgáltak. A spektrumok kiértékelése után nagy pontossággal sikerült meghatározni ezen csillagok fizikai jellemzőit $\left(T_{\mathrm{eff}}, \log g,[\mathrm{Fe} / \mathrm{H}]\right)$. Méréseinkből egyértelmú összefüggést mutattunk ki a kétmódusú cefeidák periódusaránya és fémtartalma között. Ez alapján más galaxisokban levő beat cefeidák fémtartalmára pusztán a periódusarányból is becslést tehetünk. Ezt követően, megvizsgáltuk a különböző fémességek hatását az alapmódusban és első felhangban pulzáló beat cefeidák fénygörbéjére, a fénygörbe Fourier-paramétereinek és a $[\mathrm{Fe} / \mathrm{H}]$ értékeknek a kapcsolatát. Kombináltuk az ismert galaktikus beat cefeida adatokat az OGLE-III és az OGLE-IV felmérésekből származó Kis- és Nagy-Magellán-felhôbeli adatokkal. A galaktikus cefeidák [Fe/H] értékei a saját, illetve mások által készített nagy felbontású spektroszkópián alapulnak. A Magellán-felhőkben levő csillagok $[\mathrm{Fe} / \mathrm{H}]$ értékeit az általunk meghatározott fémesség-periódusarány összefüggésből becsültük meg. Megerősíthetjük, hogy a fémesség a legerôsebb összefüggést a fénygörbe amplitúdójával és az első és a második harmonikus amplitúdóarányával $\left(R_{21}\right)$ mutat, hasonlóan a klasszikus cefeidákhoz (Klagyivik et al., 2013). Azt is megmutattuk, hogy a fémesség kevésbé korrelál a $\varphi_{31}$ paraméterrel, szemben az RR Lyrae típusú változókkal. Olyan empirikus képletet kapunk, amely felhasználható a klasszikus cefeidák [Fe/H] 
becslésére a Tejútrendszer diszkjéhez hasonló fémességú cefeidáktól, egészen az alacsonyabb fémességú Magellán-felhőkbeli cefeidákig. 


\section{2. fejezet}

\section{Irodalmi áttekintés}

\subsection{Pulzáló változócsillagok}

Az ismert csillagok nagy részénél tapasztaljuk, hogy a fényességüket változtatják az idő múlásával. Ez a fényességváltozás lehet periodikus vagy random, véletlenszerú. Ezen folyamatok mögött mindig valamilyen fizikai folyamat zajlik a háttérben. A dolgozatomban azok a csillagok kapnak szerepet, amelyek periodikus fényváltozást mutatnak és a változást a csillag pulzációja okozza. Ezért a továbbiakban ezen csillagokat mutatom be, illetve közülük is a cefeida típusba soroltakat nagyobb részletességgel, hiszen a kutatásaim során kizárólag velük foglalkoztam.

\subsubsection{Pulzáló változócsillagok általában}

Pulzáló csillagok közé soroljuk azokat a csillagokat, amelyek rezgéseket végeznek. Pulzációt nagyon sokféle típusú és evolúciós állapotú csillag mutathat, de az ismert pulzáló változócsillagok többsége óriás-, vagy szuperóriás csillag. A pulzáció csak bizonyos csillagfejlődési állapotokban stabil folyamat, ezért a szabályos pulzációt mutató csillagok a Hertzsprung-Russell-diagram (HRD) egy jól meghatározott részén, az instabilitási sávban helyezkednek el (2.1. ábra).

Kétféle csoportba soroljuk ezeket az objektumokat a pulzációjuk jellege alapján: radiálisan pulzáló, illetve nemradiálisan pulzáló csillagok. Radiális pulzáció esetén csak sugárirányú a rétegek elmozdulása, a csillag végig gömb alakú marad. A nemradiális pulzáció esetén horizontálisan is elmozdulhatnak a csillag rétegei, a külső rétegekben haladó hullámok alakulnak ki. A pulzáció során lezajló fizikai folyamatokról egy következő alfejezetben fogok részletesen írni.

A pulzáció során változik a csillag mérete és felszíni hőmérséklete, ennek következményeként a luminozitása, azaz a fényessége is. Ha a csillagot jó közelítéssel feketetest-sugárzónak tételezzük fel, a pulzáció során időben változó $R(t)$ sugár és $T(t)$ hőmérséklet miatt a luminozitás időfüggése a következő alakban írható fel: 

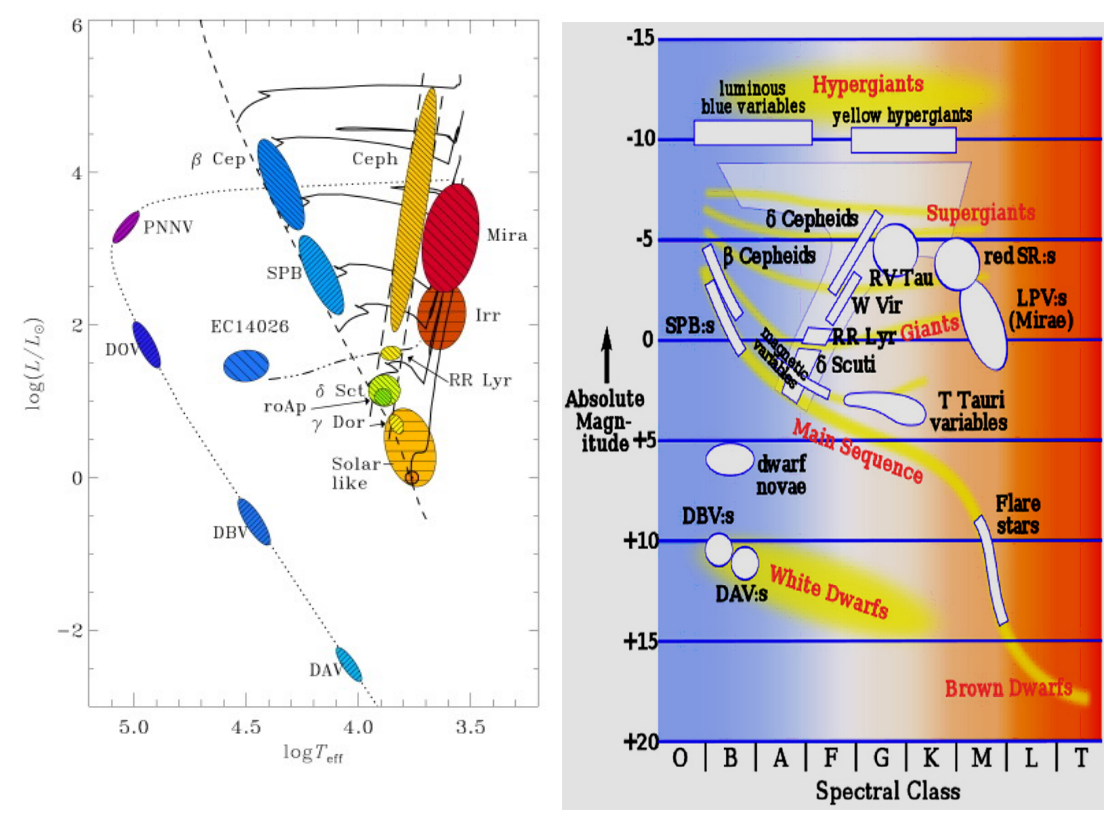

2.1. ábra. Pulzáló változócsillagok a Hertzsprung-Russell-diagramon (http://astro.u-szeged.hu és http://chandra.harvard.edu alapján)

$$
L(t)=4 \pi R^{2}(t) \sigma T^{4}(t)
$$

ahol $\sigma$ a Stefan-Boltzmann-állandó.

A megfigyelések alapján a pulzáló változócsillagok több típusba sorolhatóak. Rövid, egy napnál rövidebb periódussal pulzáló csillagok közé tartoznak az RR Lyrae csillagok és a $\delta$ Scuti csillagok. A cefeida típusba sorolt csillagok 1 és 100 nap közötti fényességváltozást mutatnak. Külön csoportot alkotnak a hosszú periódussal változó pulzátorok, a szemireguláris változók, illetve az irreguláris vörös csillagok, amelyek általában instabil, több száz napos ciklushosszal pulzáló objektumok. A következőkben bemutatom a pulzáló csillagok egyes típusait és pulzációs paramétereit a Hertzsprung-Russel-diagramon elfoglalt helyzetük szerinti csoportosításban.

A $\delta$ Scuti, RR Lyrae és cefeida csillagok a fóágra majdnem merőlegesen, ún. instabilitási sávban helyezkednek el a Hertzsprung-Russel-diagramon. Ennek a sávnak a szélessége kb. 1000 $\mathrm{K}$, a vörös és a kék határán belül lehetséges ezen csillagoknál a radiális pulzáció. A vörös határnál hidegebb csillagoknál a konvekció meggátolja a pulzációt. A kék határnál forróbb csillagoknál az ionizációs zóna, ami a pulzációt hajtaná, túl közel van a felszínhez, ahol a sưrúség kicsi a pulzáció fenntartásához. Az instabilitási sáv elnevezés némileg megtévesztô, ugyanis a sávba esô csillagok nem instabilak (Cooper \& Walker, 1994). Ellenkezőleg, a sajátrezgést végző csillagok nagyon stabilak. A sávon belüli csillagoknak azonban több mint fele nem pulzál, ugyanis a pulzációhoz 
megfelelő kémiai összetétel, mágneses tér és rotációs sebesség is szükséges.

Eleinte az instabilitási sávban található pulzáló változókat 5 fố típusba sorolták: cefeidák, W Virginis, RR Lyrae, $\delta$ Scuti, ZZ Ceti típusú változók (Marik, 1989). Az 1990-es évek intenzív kutatásainak köszönhetően ez a felosztás új típusokkal, altípusokkal egészült ki. Az alábbiakban vázlatosan ismertetem a ma elfogadott, klasszikusnak mondható csoportosítást (Becker, 1998), majd az általam vizsgált cefeida csillagokról részletes leírást adok. Forrásként felhasználtam az interneten található "Asztrofizika"1 tananyagot is.

$\gamma$ Doradus csillagok: A Hertzsprung-Russel-diagramon a $\delta$ Scuti csillagok által meghatározott instabilitási sáv hidegebb szélén találhatóak meg. Viselkedésükben hasonlóak a $\delta$ Scuti csillagokhoz.

roAp csillagok: Gyorsan forgó Ap vagyis pekuliáris A színképtípusú csillagok, erős mágneses térrel, színképükben sok fémvonallal. Pulzációjuk ezred vagy század magnitúdós fényváltozást okoz, 5-20 perces periódussal.

$\delta$ Scuti csillagok: Rövid periódusú, kis amplitúdójú fényváltozást mutató, I. populációs, fiatal, fémgazdag csillagok. Periódusidejük jellemzóen: 30 perc - 8 óra. A fényességváltozásuk néhány századmagnitúdó amplitúdójú. Pulzációjuk legtöbbször nemradiális, de előfordul radiális és nemradiális módusok keveréke is.

RR Lyrae csillagok: Ezeket a csillagokat általában halmazváltozóknak is hívják, mert nagy számban gömbhalmazokban fordulnak elő. A jól meghatározott periódus-luminozitás relációjuk alapján, előszeretettel használják őket távolságmeghatározásra. Ebbe a csoportba tartozó csillagok pulzációs periódusa 0,2-0,4 nap közötti lehet. II. populációs, öreg, ezáltal fémszegény változók. Három alcsoportját különböztetjük meg a fénygörbéik alapján:

ab típusú: Nagyobb amplitúdójú, hosszabb periódusú, alapmódusban pulzáló csillagok. Fénygörbéjük jellemzően aszimmetrikus.

c típusú: Első felhangban pulzálnak. Fénygörbéjük közel szinuszos.

d vagy kétmódusú típusú: Pulzációjuk során az alaprezgés és az elsô felhang egyszerre van jelen. A periódusidők aránya általában: $P_{1} / P_{0} \approx 0,746 \pm 0,002$. Nagyon valószínú, hogy ezek a csillagok éppen módusváltáson esnek át, átmenetet képezve az elóbb bemutatott két típus között.

BL Herculis csillagok: Fényességváltozásuk periódusa 1-4 nap közötti. Idôs, II. típusú cefeida csillagok. A következő fejezetben bővebben írok róluk.

W Virginis csillagok: Az előző csoporthoz hasonlóan idős, II. típusú cefeida csillagok. 6-35 nap közötti fényességváltozással. A következő fejezetben szintén visszatérek rájuk.

Cefeidák vagy $\delta$ Cephei csillagok: Radiális módusban pulzáló, I. populációs óriás- vagy szuperóriás csillagok. Részletesebben róluk is a következő fejezetben ejtek szót.

A második nagyobb csapatot a fősorozaton levő pulzáló változócsillagok teszik ki. Bemutatásuk a fősorozaton felfelé haladó sorrendben történik:

\footnotetext{
${ }^{1}$ http://astro.u-szeged.hu/oktatas/asztrofizika/html/asztrofizika.html
} 
Nap-típusú oszcillációt mutató vagy SO csillagok: Nemradiális, p- és/vagy g-módusú akusztikus oszcillációt mutató csillagok.

Rövid periódusú B színképtípusú (SPB) változók: Periódusidejük meghaladja a 9 órát. B színképtípusú csillagok, melyek multiperiódussal és nemradiális g-módusban is pulzálhatnak.

Szintén népes csoportot alkot az óriáság pulzátorainak csoportja, ismertetésük a korábbiakhoz hasonlóan a fôsorozattól távolodó sorrendet követ:

Mira vagy LPV csillagok: Vörös óriás és szuperóriás csillagok, melyek radiális pulzációt végeznek. A pulzáció periódusa átlagosan 1 év, de összességében 80-1200 nap közötti periódus jellemző rájuk. A fényváltozás amplitúdója 2,5 magnitúdónál nagyobb. Néhányuknál többszörös periodicitás figyelhetô meg.

Lc csillagok: Lassú, szabálytalan, kb. 1 magnitúdó amplitúdójú fényességváltozást mutató M típusú szuperóriás csillagok.

Lb csillagok: Az Lc csillagokhoz teljesen hasonló késői színképtípusú óriás csillagok.

SRd változók: Félszabályos sárga óriás és szuperóriás csillagok. Spektrumukban emissziós vonalak is megjelenhetnek. Pulzációjukra a 30-1100 napos periódus, néhány tizedtôl négy magnitúdóig terjedő amplitúdó jellemző.

SRc változócsillagok: Szintén félszabályos változók, de késői színképtípusú szuperóriások.

SRb csillagok: A Mirákhoz hasonló csillagok, gyakori a többszörös periodicitás a pulzációjukban és a periódus, illetve amplitúdó változása.

SRa változók: Vörös óriás csillagok. Fényváltozásuk 35 és 1200 nap közötti periódussal és 2,5 magnitúdónál kisebb amplitúdóval következik be.

A Hertzsprung-Russel-diagram egyéb helyein is találunk olyan óriás és szuperóriás csillagokat, amelyek pulzációt végeznek:

Be csillagok: Szintén B színképtípusú tömegükből folyamatosan veszítő csillagok, gyors forgással. Pulzációból származó kis amplitúdójú, kváziperiodikus változást mutatnak.

$\alpha$ Cygni változók: A színképtípusú, kvázi-periodikus szuperóriás csillagok. Periódusidejük néhány nap és néhány hét között változik, kb. 0,1 magnitúdós amplitúdóval. Nemradiális módusban pulzálnak.

LBV vagy S Doradus csillagok: Fényes eruptív kék változócsillagok. A pulzációs instabilitásuk miatt kialakuló erôs csillagszél hatására folyamatos tömegvesztést szenvednek. A fénygörbéjük alapján, 1 magnitúdónál nagyobb a fényváltozás amplitúdója. Hubble-Sandage-változóként is emlegetik óket.

Korábban említettem, hogy a pulzáló változócsillagok közé sokféle csillagfejlődési állapotban lévő csillag hozzátartozik, így nem meglepő az, hogy a törpe csillagok között is találunk képviselőiket:

ZZ Ceti csillagok: Néhány perces periódussal, nemradiálisan pulzáló hidrogén-légkörú fehér törpék. Pulzációjuk multiperiodikus, 0,001-0,3 magnitúdó amplitúdóval.

SX Phoenicis csillagok: Öreg, II. populációs, szubtörpe csillagok. Néhány órás periódussal 
pulzálnak, melynek amplitúdója kisebb, mint 0,7 magnitúdó. Több radiális és nemradiális módus is megjelenik a pulzációjukban.

DV vagy DBV változók: Szintén multiperiodikus, nemradiálisan pulzáló fehér törpék, de nem hidrogén-, hanem héliumlégkörrel. Fényességváltozásuk 100-1000 másodperc periódusú.

GW Vir vagy DOV csillagok: Ebbe a csoportba nagyon forró leendő fehér törpék tartoznak. Multiperiodikus, nemradiális a pulzációjuk, 400-1200 másodperces periódussal.

Vannak olyan pulzátorok, melyek az eddig említett egyik csoportba sem sorolható pulzáló változók. Ezeket is röviden bemutatom, a teljesség kedvéért:

RV Tauri csillagok: Az instabiltási sáv és az óriás ág között helyezkednek el, közel a klasszikus I. típusú cefeidákhoz. II. populációs öreg szuperóriás csillagok. 30-150 napos periódusuk alatt a fényességváltozás legfeljebb 5 magnitúdó. A fénygörbéjük jellegzetessége, hogy két különböző mélységú minimumot tartalmaz. Hovatartozásukról sokáig vita folyt, jelenleg a II. típusú cefeidák közé sorolják őket, ezért a következő fejezetben bővebben bemutatom még ôket.

Hidrogénszegény pulzáló csillagok: Olyan csillagok, melyek 0,1- 40 napos periódusú pulzációs változást mutatatnak, színképükben gyenge hidrogénvonalak vannak, vagy előfordulhat az is, hogy teljesen hiányoznak.

R Coronae Borealis csillagok: Eruptív hidrogénszegény, széngazdag változócsillagok. Kváziperiodikus pulzációt végeznek 30-100 napos periódussal, melynek amplitúdója nagyobb, mint 1 magnitúdó.

A fentiek mellett még számos egyéb változócsillag-típust elkülöníthetünk. Ezek azonban nem képezik a jelen dolgozat tárgyát, ezért a továbbiakban a cefeida változócsillagokra koncentrálok.

\subsubsection{Cefeidák}

A dolgozatomban szereplő csillagok egytől-egyig a cefeida változók közé tartozik, így ebben az alfejezetben ezt a népes csapatot igyekszem részletesebben megismertetni. A cefeidák az egyik legkedveltebbek a csillagászati kutatások szempontjából. Nagy abszolút fényességük miatt mind a Tejútrendszerben, mind extragalaxisokban megfigyelhetőek. Relatíve nagy amplitúdóval pulzálnak, jellemző periódusidejük néhány naptól kb. 100 napig terjedhet, ezért nem túl hosszú idő (néhány év) alatt is sokciklusnyi megfigyelési adat gyújthetô róluk, amelyekből az elméleti modellek jól tesztelhetőek. A cefeidák tanulmányozásában nagy előrelépést hozott, amikor felismerték, hogy a cefeidák közé sorolt csillagok között is vannak különböző csoportokba, populációkba sorolandó csillagok. 5 nagyobb csoportba lehet ôket sorolni a koruk és fejlődési állapotuk alapján: $\delta$ Cephei, W Virginis, BL Herculis, RV Tauri csillagok és az anomális cefeidák.

BL Herculis csillagok: szintén radiálisan pulzáló, II. típusú változók. Különlegességük, hogy a fénygörbéjükön a leszálló ágon egy púp látható. 1-4 nap a periódusidejük. 
W Virginis csillagok: II. típusú cefeidaként is szokták emlegetni ôket. Mind fénygörbéjük, mind periódus-fényesség reláción elfoglalt helyzetük alapján nagyon hasonlítanak a $\delta$ Cephei változókhoz. Kezdetben ezért össze is tévesztették az utóbbi kategóriával. A W Virginis csillagok idősebb, kisebb fémtartalmú, némileg alacsonyabb fényességú II. populációs kistömegú csillagok. 0,3-1,2 amplitúdójú fényességváltozásukat 6-35 nap közötti periódussal ismétlik.

RV Tauri típusú változócsillagok: F színképosztályú csillagok, nem teljesen szabályos fényességváltozással, amelynek periódusideje 30-150 nap között van. A fénygörbéjük nagyon jellegzetes a főminimumok között található kisebb mellékminimumokkal. Két alosztálya ismert, az RVa állandó középmagnitúdóval, míg az RVb változó középmagnitúdóval rendelkezik. Fényességváltozásukból sokáig arra következtettek, hogy ezek a csillagok átmenetet képeznek a cefeidák és a Mira csillagok között. Ugyanaz a mechanizmus, a hidrogén- és héliumionizáció gerjeszti ôket. A vizsgálatok alapján jellenleg a II. típusú cefeidák közé sorolják őket.

Anomális Cefeidák: az RR Lyrae-khez teljesen hasonló csillagok, de nagyobb a luminozitásuk. Többnyire extragalaxisokban fordulnak elő.

$\delta$ Cephei csillagok: Ők a tipikus klasszikus cefeidák. Radiális pulzációt mutató, I. populációs, fiatal, fényes sárga szuperóriások. 1784. szeptember 10-én Edward Pigott észlelte az Eta Aquilae fényességváltozását, amely a cefeida változók első ismert képviselője lett. Ezen csoport névadója azonban a Delta Cephei lett, amelyet néhány hónappal később John Goodricke fedezett fel. Általában a galaxisok spirálkarjaiban találhatóak meg. Teljesen szabályos 1 és 135 nap közötti periódusú változásuk során 0,1-2 amplitúdójú fényességváltozást tapasztalhatunk (2.2. ábra). A Hertzsprung-Russel-diagramon az instabilitási sávban helyezkednek el. A fényváltozásuk periódusának logaritmusa egyenesen arányos az abszolút fényességükkel, ezért a fényváltozásuk méréséből meghatározható a távolságuk is. Ezt a periódus-fényesség relációt használják a extragalaxisok távolságainak megállapítására. Ezen csillagok közül néhány többszörös periodicitást mutat, őket nevezzük kétmódusú vagy beat cefeidáknak. Ezeknek a csillagoknak egy külön alfejezetet szánok, hiszen a kutatásaim célpontjai ők voltak.

\subsubsection{Kétmódusú cefeidák}

A több módusú pulzáló csillagok kutatása közkedvelt a csillagászok között. A kétmódusú vagy beat cefeidák kicsi de egyre népesebb csoportja is fontos szerepet tölt be a kutatásokban (Balona, 1985). A kétmódusú cefeidák a klasszikus cefeidák alcsoportjába tartoznak, amelyek két sugárirányú pulzálási módban egyidejúleg pulzálnak (Petersen \& Takeuti, 2001). A galaxisunkban jelenleg 23 egyértelmúen ebbe a csoportba sorolható csillagot ismerünk (Ishida, 2017). Ezen csillagok $P_{1} / P_{0}$ periódusaránya 0,6967 és 0,7195 közé esik, két kivétellel, amelyek periódusaránya 0,80 (CO Aur és V1048 Cen), de ezek a csillagok első- és a második felhangban pulzálnak. 


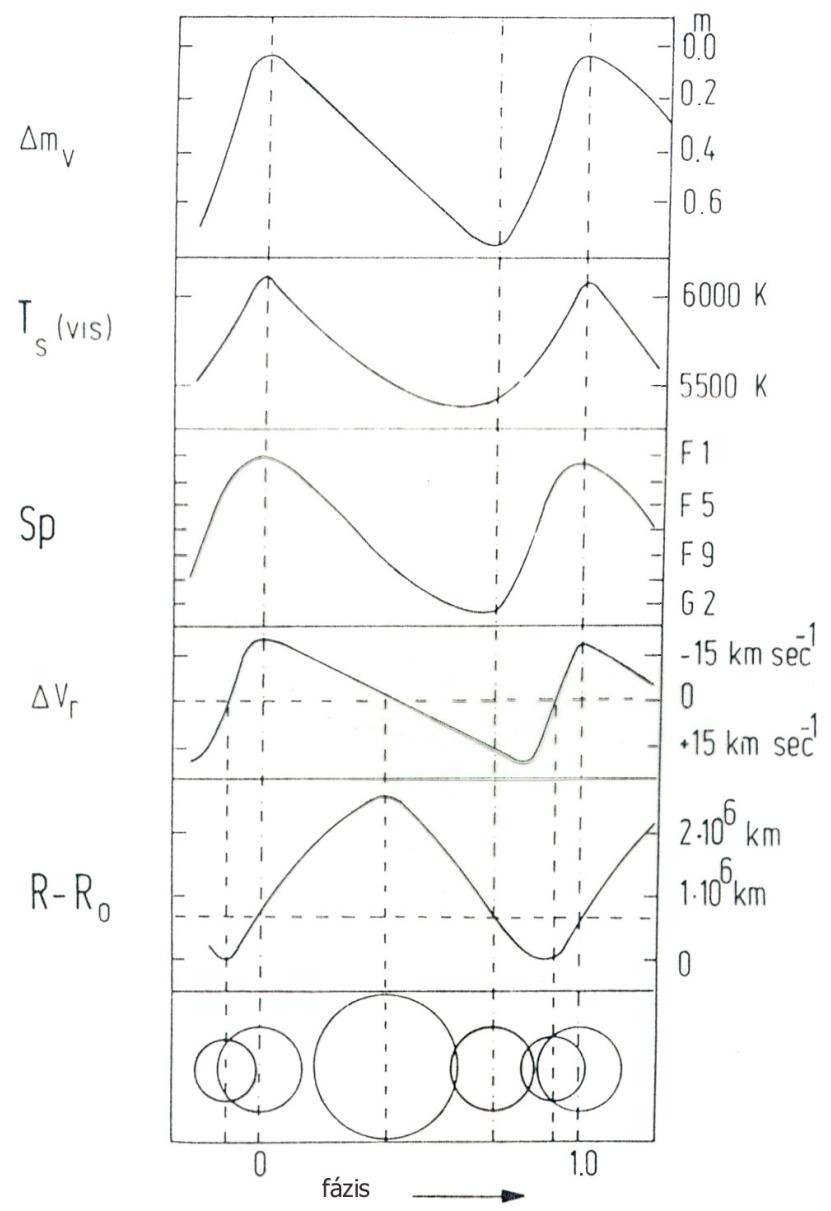

2.2. ábra. A cefeida csillagok fényességének, hőmérsékletének, színképtípusának, radiális sebsségének és sugarának változása egy pulzációs ciklus alatt (http://astro.u-szeged.hu alapján). 
A 21 alapmódusban is pulzáló csillag közül 20 cefeida alapmódushoz tartozó periódusa 2,139 és 6,293 nap közé esik. A nemrég felfedezett V371 Per sokkal rövidebb periódussal rendelkezik, mint a többiek és a periódusaránya is egy kicsit magasabb, mint a többié. Wils et al. (2010) arra a következtetésre jutott, hogy a magasabb periódusarány azt jelezheti, hogy ennek a csillagnak a fémessége sokkal alacsonyabb, mint a többi galaktikus beat cefeida fémessége. Minderre Buchler \& Szabó (2007) cikkében megadott periódus, periódusarány és fémesség reláció által meghatározott értékekből következtettek. Nagy valószínúséggel ez a csillag a galaxisunk vastag diszkjében vagy a galaxisunk halójában található. A V371 Per a számítások szerint először halad át az instabilitási sávon, mert a lineáris nemadiabatikus pulzációs modellből számított tömege nagyobbnak adódik, mint amekkora az evolúciós tömege azoknak az objektumoknak, amelyek másodszor vagy többedszer haladnak át ezen a sávon. Ezt a spektroszkópiai mérések eredményei is alátámasztották (Kovtyukh et al., 2012, 2016). A 2.1.táblázat a Tejútrendszerben található kétmódusú cefeidák fontosabb paramétereit foglalja össze.

2.1. táblázat. A galaktikus beat cefeida csillagok fôbb paraméterei

\begin{tabular}{lrcccc}
\hline Csillag & $\begin{array}{r}\mathrm{V} \\
\text { (mag) }\end{array}$ & $\begin{array}{c}P_{0} \\
\text { (nap) }\end{array}$ & $\begin{array}{c}P_{1} \\
\text { (nap) }\end{array}$ & $\begin{array}{c}P_{2} \\
\text { (nap) }\end{array}$ & $P_{1} / P_{0}$ \\
\hline \hline EW Sct & 8,0 & 5,823 & 4,068 & - & 0,699 \\
BQ Ser & 9,6 & 4,272 & 3,012 & - & 0,705 \\
V367 Sct & 11,6 & 6,293 & 4,385 & - & 0,697 \\
V458 Sct & 9,8 & 4,841 & 3,385 & - & 0,699 \\
U TrA & 7,8 & 2,568 & 1,825 & - & 0,710 \\
V1210 Cen & 10,3 & 4,317 & 3,037 & - & 0,703 \\
BK Cen & 10,0 & 3,174 & 2,223 & - & 0,700 \\
UZ Cen & 8,8 & 3,334 & 2,355 & - & 0,706 \\
EY Car & 10,3 & 2,876 & 2,036 & - & 0,708 \\
Y Car & 8,2 & 3,639 & 2,560 & - & 0,703 \\
GZ Car & 10,2 & 4,160 & 2,934 & - & 0,705 \\
V701 Car & 11,1 & 4,089 & 2,869 & - & 0,702 \\
AP Vel & 10,0 & 3,128 & 2,200 & - & 0,703 \\
AX Vel & 8,2 & 3,674 & 2,593 & - & 0,706 \\
BE Pup & 13,5 & 2,870 & 2,048 & - & 0,714 \\
VX Pup & 8,2 & 3,012 & 2,139 & - & 0,710 \\
DZ CMa & 12,1 & 2,311 & 1,700 & - & 0,719 \\
TU Cas & 7,6 & 2,139 & 1,518 & - & 0,710 \\
AS Cas & 11,8 & 3,025 & 2,156 & - & 0,713 \\
V825 Cas & 12 & 3,734 & 2,653 & - & 0,710 \\
V1048 Cen & 10,5 & - & 0,922 & 0,743 & 0,806 \\
CO Aur & 7,7 & - & 1,783 & 1,428 & 0,801 \\
V371 Per & 11,0 & 1,737 & 1,270 & - & 0,731 \\
\hline
\end{tabular}

A saját galaxisunkon kívül is ismerünk kétmódusú cefeidákat, főleg a Magellán-felhôkben sikerült nagyobb számban felfedezni ezt a típusú változócsillagot. A számuk jelentôsen megnövekedett 
a MACHO (Massive Compact Halo Objects) és OGLE (Optical Gravitational Lensing Experiment) projektek révén. 1994-ben Alcock és munkatársai a MACHO megfigyeléseket tartalmazó fotometria adatbázis felhasználásával 45 beat cefeidát fedeztek fel a Nagy-Magellán-felhőben (Alcock et al., 1995). Ezek közül 30 alapmódusban és elsô felhangban pulzál, miközben a periódusok aránya 0,72 körüli. Ez az arány kicsivel magasabb, mint a galaktikus beat cefeidáknál tapasztalt, ami szintén alátámasztja azt, hogy a periódusarány, illetve a pulzáció periódusai szoros összefüggést mutatnak a fémtartalommal. 15 csillag első és második felhangban rezeg, a többségük periódusaránya megközelítőleg 0,8. A MACHO adatait felhasználva végül 73 beat cefeida került felfedezésre a Nagy-Magellán-felhőben (Welch et al., 1996). A Kis-Magellán-felhőben az OGLE-III változócsillag katalógus csillagai közül 4630 klasszikus cefeida van, melyből a kiértékelések alapján 59 kétmódusú cefeida van, amelyik alapmódusban és első felhangban pulzál, 215 csillag rezeg elsô és második felhangban. Az adatbázis alapján három egyidejúleg 3 módusban pulzáló cefeidát is sikerült azonosítani (Soszynski et al., 2010). A legfrissebb adatok alapján az OGLE program jelenlegi állása szerint a Magellán-felhőkben 9535 klasszikus cefeidát találtak, melyből 711 csillag kétmódusú cefeida és 9 hárommódusú (Soszynski et al., 2015).

A Magellán-felhők után az M33-ban is sikerült 5 beat cefeidát azonosítani (Beaulieu et al., 2006). Mind az öt csillag alapmódusban és elsô felhangban pulzál. A 2.2. táblázatban a csillagok periódusadatait láthatjuk az előbb említett cikk alapján.

2.2. táblázat. Az M33-ban talált beat cefeida csillagok főbb paraméterei

\begin{tabular}{cccc}
\hline ID & $\begin{array}{c}P_{0} \\
\text { (nap) }\end{array}$ & $\begin{array}{c}P_{1} \\
\text { (nap) }\end{array}$ & $P_{1} / P_{0}$ \\
\hline \hline $\mathrm{A}$ & 4,705 & 3,385 & 0,719 \\
$\mathrm{~B}$ & 3,977 & 2,861 & 0,719 \\
$\mathrm{C}$ & 3,827 & 2,714 & 0,709 \\
$\mathrm{D}$ & 6,176 & 4.333 & 0,701 \\
$\mathrm{E}$ & 6,187 & 4,335 & 0,700 \\
\hline
\end{tabular}

2013-ig beat cefeidát csak a Galaxisunkban, a Magellán-felhőkben és az M33-ban ismertek. Érdekesség, hogy az M31-ben lévő 2000-nél több cefeida közül nem volt kétmódusú (Poleski, 2013). Majd az M31 archív adataiban Poleski kimondottan, szisztematikusan kétmódusú cefeidákat keresett, és ennek meg is lett az eredménye, mert négy ilyen csillagot fedezett fel. Az egyik csillag első és második felhangban pulzál, két csillag pedig alapmódusban és első felhangban. Az alapmódushoz tartozó periódusuk 9,392 és 9,163 nap. A negyedik csillag nem sorolható egyértelmúen a kétmódusú cefeidák közé, többek között a periódusaránya miatt, ami 0,589-nak adódott. A 2.3. táblázatban található az Androméda-ködben talált négy kétmódusú cefeida pulzációs periódusainak értéke.

A 2.3. ábrán az ismert alapmódusban, első és/vagy második felhangban pulzáló kétmódusú cefeidák periódus adataiból készült Petersen-diagram látható. A cefeidák kis hányada pulzál egyidejứleg két módusban, az eddigiekben összefoglaltak alapján, rendszerint alapmódusban és elsô 
2.3. táblázat. Az M31, Androméda-ködben talált beat cefeida csillagok főbb paraméterei

\begin{tabular}{lccc}
\hline ID & $\begin{array}{c}P_{0} \\
\text { (nap) }\end{array}$ & $\begin{array}{c}P_{1} \\
\text { (nap) }\end{array}$ & $P_{1} / P_{0}$ \\
\hline \hline J00450019+4129313 & 1,695 & 1,361 & 0,803 \\
J010.6063+40.8608 & 9,291 & 6,555 & 0,800 \\
J010.9364+41.2504 & 9,163 & 6,362 & 0,806 \\
J011.3583+42.0404 & 10,467 & 6,161 & 0,797 \\
\hline
\end{tabular}

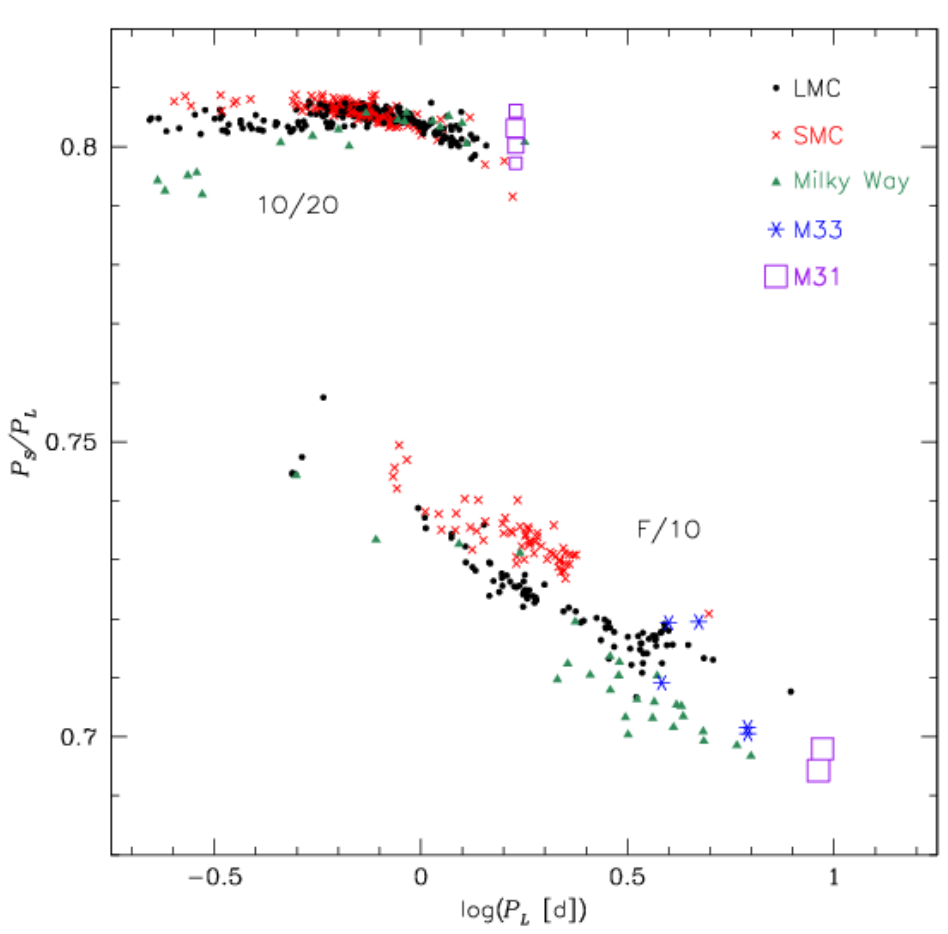

2.3. ábra. Az ismert $\mathrm{F} / 1 \mathrm{O}$ és $1 \mathrm{O} / 2 \mathrm{O}$ cefeidák Petersen-diagramja. Az ábrán a $P_{\mathrm{L}}$, illetve a $P_{\mathrm{S}}$ értelemszerúen a hosszabb, illetve a rövidebb periódust jelöli (Poleski, 2013).

felhangban, esetenként a másodfelhangban. A cefeidák nagyon csekély száma pulzál háromféle módusban (hárommódusú) egyszerre. 2008-ban jelentették be (Soszynski et. al, 2008) három új hárommódusú cefeida felfedezését a Nagy-Magellán-felhőben. Kettő alapmódusban, elsô felhangban és második felhangban pulzál, és egy pedig egyidejűleg az elsô, második és harmadik felhangban. Így a hárommódusú cefeidák száma az Nagy-Magellán-felhốben ötre emelkedett. Napjainkban az OGLE adatok alapján 8 ilyen csillagot ismerünk. A Nagy-Magellán-felhőben 5, a Kis-Magellán-felhôben 3 ilyen cefeida lett eddig felfedezve, ebből 4 csillag alapmódosúban, elsô felhangban valamint második felhangban pulzál, és szintén 4 az első, második és harmadik felhangban (Soszynski et. al, 2010). 


\subsection{Pulzációelmélet alapjai}

A pulzáló változócsillagokban a rezgést olyan hajtóerô hozza létre, amely a csillapítás ellenére periodikus oszcillációt tud fenntartani. A csillag plazma állapotú anyagának kitágulásaösszehúzódása egy nemadiabatikus körfolyamat, amely energiadisszipációhoz vezet, ezért a stabil, folyamatos pulzációhoz egy öngerjesztô mechanizmus szükséges. Négyféle mechanizmus ismert, ami a ezen csillagok pulzációját fenntarthatja. A $\gamma$-mechanizmus, a konvektív hajtás, a sztochasztikus gerjesztődés és a $\kappa$-mechanizmus.

A $\gamma$ mechanizmus folyamán a magfúziós folyamat rátája változik a csillagban a pulzáció során. Ezt a folyamatot a dízelmotorok múködéséhez szokták hasonlítani. A folyamat kiváltó oka, hogy a csillagnak az a rétege amelyben a fúzió zajlik, összenyomódik, ennek hatására a hőmérséklet növekszik és több energia szabadul fel. A keletkező energia térfogat-növekedést okoz, tehát a csillag kitágul. A térfogat-növekedés nyomáscsökkenéssel jár, aminek hatására az energiatermelés csökken, a fúziós réteg térfogata visszacsökken, a réteg visszahullik, majd a ciklus kezdődik elölről. Ez a mechanizmus többféle csillagtípus pulzációját tartja fenn, többek között a Napunk pulzációjában is szerepe van.

A konvektív hajtás során a csillag belső konvektív zónája elnyeli a belülről jövő fluxust. Az összehúzódási szakaszban felgyülemlett energiát az azt követő expanziós fázisban adja át annak a rétegnek, amelyik a pulzációt végzi. Ez a mechanizmus szintén hasonló, mint egy dugattyú múködése. A DA, DB fehér törpe csillagok, a $\gamma$ Doradus csillagok pulzációja ezzel a hajtóerővel magyarázható, de szerepet játszik egyes cefeida és mira csillagok pulzációjában is.

A harmadik mechanizmus a sztochasztikus gerjesztődés. Ez a Nap és a Nap-típusú oszcillációt mutató csillagok pulzációját okozza. A csillag felszínhez közeli konvektív zónában fellépô turbulencia sztochasztikus gerjesztődést vált ki. A nagyon erôs konvektív mozgás a felszínhez közeli rétegekben akusztikus zajt hoz létre széles frekvenciatartományban, amely aztán oszcillációs módusokat gerjeszt. Ezeknek a csillagoknak a felszínén sok a konvektív cella, amelyek egymástól függetlenül, véletlenszerúen mozognak, ezért lesz ez a gerjesztési folyamat sztochasztikus jellegú. A kialakuló oszcillációk amplitúdója az időben folyamatosan, erôsen változik.

A pulzáló változócsillagok legtöbbjénél a rezgések kialakulása és fennmaradása a $\kappa$-mechanizmushoz köthetô. Többek között az instabilitási sávban található pulzáló csillagok oszcillációjának ez a legvalószínúbb magyarázata. A csillag belsejéből a termelődött energia kifelé áramlik, ennek hatására a csillag felszínhez közeli rétegeiben hőmérséklet-emelkedés következik be. A megnövekedett hőmérséklet következményeként az ionizáció foka megnő, vagyis több lesz a szabad elektron. A több szabad elektron opacitásnövekedést okoz. Az opacitás megnövekedése miatt nő a rétegben elnyelődő fotonenergia, ami nyomásnövekedést okoz, emiatt az adott réteg kitágul. Ez a tágulás nem 
áll le az egyensúlyi sugárnál, a csillag az egyensúlyi méreténél nagyobbra tágul. A tágulás miatti, térfogat-növekedés viszont hőmérséklet-csökkenéssel jár, ezért az ionizáció foka lecsökken, így az opacitás szintén kisebb lesz, a térfogat csökken, vagyis a réteg visszahúzódik. A réteg újabb felmelegedésével az előzô körfolyamat újra kezdődik.

Ez a folyamat csillag típusonként más-más ionizációs rétegben zajlik. A mechanizmus lejátszódhat a HeII részleges ionizációs zónájában, mint például a $\delta$ Cephei, az RR Lyrae és a $\delta$ Scuti csillagok esetében, valamint a HI és HeI zónákban a roAp csillagok esetén. A mira változóknál a HI ionizációs zónában, a $\beta$ Cephei és SPB csillagoknál a vas-csoport elemeinek ionizációs zónájában történik a pulzációt kiváltó öngerjesztő folyamat.

A radiális pulzáció egy fundamentális összefüggése a periódus-sưrúség reláció. Már a legegyszerúbb, lineáris, adiabatikus pulzációt leíró egyenletekből is levezethető, hogy a kialakuló rezgés periódusa fordítottan arányos a csillag átlagos sûrúségével. A reláció a következô módon írható fel:

$$
P \sqrt{\frac{\rho}{\rho_{\odot}}}=Q,
$$

ahol a $P$ periódust napban, a $\rho$ átlagos sûrúséget Nap-egységben adjuk meg, a $Q$ ebben az esetben a pulzációs konstanst adja. A pulzációs konstans elnevezés megtévesztő, mert ez az érték nem egy állandó. A $Q$ értéke a konkrét csillag belsô szerkezetétôl, sûrúségeloszlásától függ. Hasonló csillagokra viszont jó közelítéssel ugyanazt az értéket kapjuk rá, ezért tekinthetjük konstansnak. Az összefüggés alapján a kisebb átlagsúrúségú csillagok oszcillációs periódusai hosszabbak. Ez a megfigyelésekkel tökéletesen összhangban van. Az instabilitási sávban a fősorozattól távolodva a csillagok átlagsưrűsége egyre csökken, a pulzációs periódus pedig egyre hosszabb. Az instabilitási sáv tetején találhatóak a hosszú, 50-100 napos periódusú cefeidák, míg a fôsorozathoz közel a rövid periódusú $\delta$ Scuti változók helyezkednek el. $Q$ értéke minden radiális módusra más, az alaprezgésre $Q \approx 0,03$ nap, a magasabb felhangokra egyre kisebb.

A pulzációs mechanizmusok után mindenképpen szót kell ejteni a pulzációs módusokról is. A pulzációelmélet alapján egy csillag többféle módusban is végezhet rezgéseket, hasonlóan a sípok, húrok és membránok oszcillációihoz. Az egyes módusokat periódusukkal, illetve a rezgési képpel lehet jellemezni. Az elsô esetben mikor a csillag alapmódusban, vagyis fundamentális módusban végzi a rezgést, a csillag egésze egyszerre húzódik össze és tágul ki, a csillag belsejében nincs csomófelület. Az alaprezgésen túli, magasabb módusokat a pulzáció során nem felharmonikusoknak, hanem felhangoknak hívjuk. Az elsô felhang azt jelenti, hogy van egy csomófelület valahol 2/3 csillagsugárnál, amelyen kívül és belül esô régiók ellentétes fázisban végzik mozgásukat (2.4 ábra).

Az instabilitási sávban a cefeidák, illetve az RR Lyrae csillagoknál általában egy módus gerjesztett és ez legtöbbször a leghosszabb periódusú alapmódus. A megfigyelések alapján elófordul, 


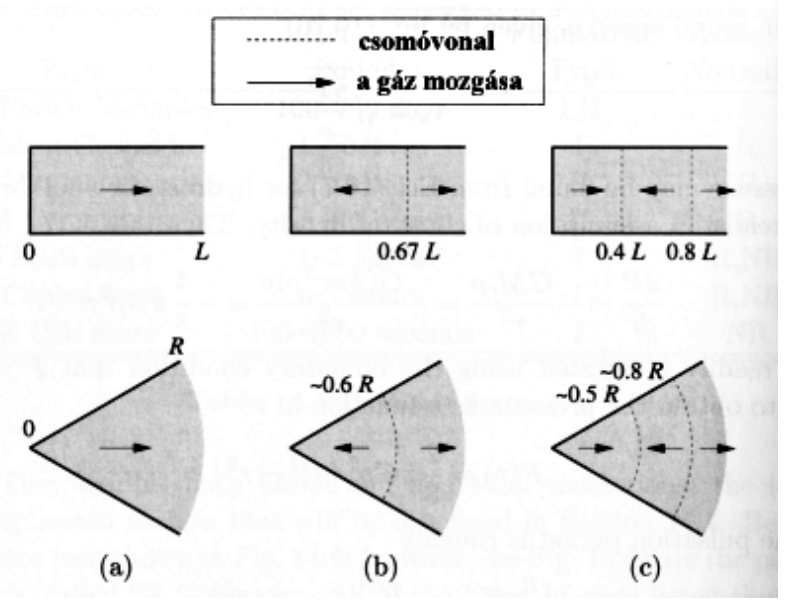

2.4. ábra. A sípban rezgô légoszlop és egy pulzáló csillag összehasonlítása. (a) alapmódus, (b) első felhang, (c) második felhang. (http://astro.u-szeged.hu/)

hogy az elsô felhang a gerjesztett. A 2.5. ábrán jól látszik, hogy az alapmódusban pulzáló csillagok jól elkülönülnek az elsô felhangban pulzáló változóktól (Soszynski et al., 2015, Udalski et al., 2015). Az, hogy egy csillagban melyik módus válik gerjesztetté, nagymértékben a csillag szerkezetétôl függ. Ritkán, de elôfordul az az eset is, hogy egy csillagon belül egyszerre két módus is gerjesztett, mint a már korábban bemutatott kétmódusú cefeidák esetén is, sôt még ritkábban, de létezik három módusban pulzáló cefeida is (lásd. előző alfejezet) 


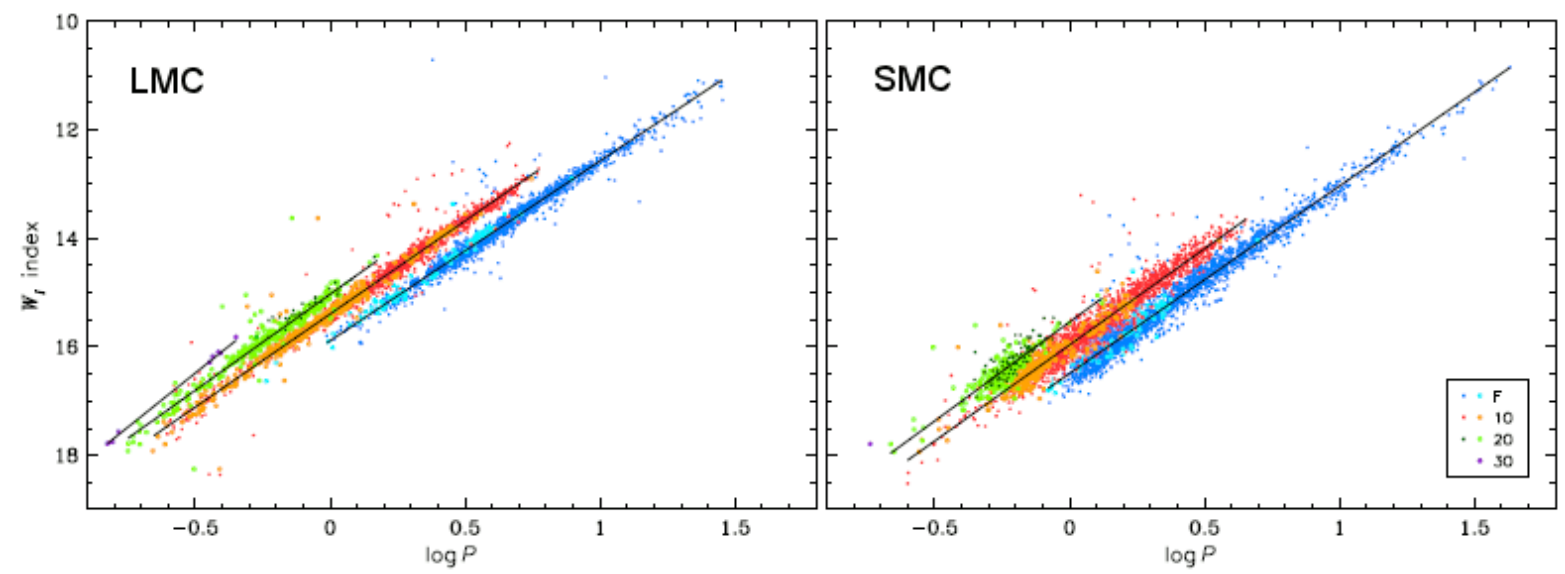

2.5. ábra. Az ábra az OGLE adatbázisban található Magellán-felhőkbeli alapmódusú, első és második felhangban pulzáló cefeidák adatai alapján frissített periódus-fényesség relációt ábrázolja. I és V szúrôvel készült felvételek alapján a WI extinkciómentes Wesenheit indexet. 


\section{3. fejezet}

\section{Mérési módszerek elméleti alapjai}

\subsection{Fotometria}

\subsubsection{Fotometria alapjai}

A csillagok egyik jól mérhető állapothatározója a fényesség. Egy csillagnak kétféle fényessége van, a látszó és az abszolút fényesség. A látszó fényesség a földfelszínrôl mért értéket jelenti, míg az abszolút fényesség a 10 parszek távolságból (elvileg) mérhető fényesség. Az i.e. II. században Hipparkhosz készítette el az elsố csillagkatalógust, amelyben a csillagok fényességéhez számszerú értékeket rendelt. A csillagokat 6 fényességkategóriába sorolta be. 6 magnitúdósak azok a csillagok lettek, amelyek szabad szemmel még éppen megfigyelhetőek, a legfényesebbek csillagok pedig az 1 magnitúdós értéket kapták. A ma is használt magnitúdó skálát az 1850-es években Norman Pogson csillagász ötlete alapján úgy határozták meg, hogy 5 magnitúdó különbség százszoros fluxusbeli különbségnek feleljen meg. Egy csillag látszó fényességét a következő egyenlettel adhatjuk meg:

$$
m=-2,5 \log f+c,
$$

ahol $m$ a csillag látszó magnitúdója, $f$ a csillagról jövő fény sugárzási árama.

Két csillag magnitúdójának különbségére fennáll:

$$
m_{1}-m_{2}=-2,5 \log _{10} \frac{f_{1}}{f_{2}}
$$

ahol $m_{1}$ és $m_{2}$ a két csillag látszó fényessége magnitúdóban, $f_{1}$ és $f_{2}$ pedig a mért fluxusuk.

A magnitúdóskála a fenti definícióból is látszik, hogy egy relatív skála, a csillag fényessége egy referenciacsillag fényességéhez képest van megadva. Az adott referenciaszint attól függ, hogy éppen milyen fotometriai rendszert használunk. A legrégebbi fotometriai rendszer a Vega magnitúdórendszer. Ennél a rendszernél a referenciaszint a Vega látszó fényessége, ami minden hullámhosszon kb. 0 magnitúdó. A Vega magnitúdó definíciója a következő egyenlettel adható 
meg:

$$
m=-2,5 \log _{10}\left(\frac{F}{F_{\text {Vega }}}\right)=-2,5 \log _{10} F+Z P,
$$

ahol ZP a zéruspont, ami hullámhosszfüggő.

Szintén csillagászati magnitúdó rendszer az AB magnitúdó rendszer (Oke, 1974). A monokromatikus $\mathrm{AB}$ magnitúdó a spektrális fluxus-súrúség logaritmusaként határozható meg. Egyenletben kifejezve a következôképpen adható meg:

$$
m_{\mathrm{AB}}=-2,5 \log _{10}\left(\frac{F_{\mathrm{v}}}{3631 \mathrm{Jy}}\right)=-2,5 \log _{10} F_{\mathrm{v}}-48,6
$$

ahol $1 \mathrm{jansky}(\mathrm{Jy})=10^{-26} \mathrm{~W} / \mathrm{m} / \mathrm{Hz}=10^{-23} \mathrm{erg} / \mathrm{s} / \mathrm{cm}^{2} / \mathrm{Hz}$, az $F_{\mathrm{v}}$ fluxus mindenképpen frekvenciaegységú. A zéruspont minden hullámhosszon azonos, a rendszernek nincs referencia-objektuma, a rendszer univerzális.

A fotometriai mérések minden esetben valamilyen szûrőn keresztül készülnek, ezért ezeket is figyelembe kell venni. A következő egyenlet a Vega-magnitúdó definíciója szúrôs fotometriai rendszerben:

$$
m_{\mathrm{i}}=-2,5 \log _{10}\left(\frac{\int R_{\mathrm{i}}(\lambda) \lambda F_{\lambda} d \lambda}{\int R_{\mathrm{i}}(\lambda) \lambda F_{\lambda}(\operatorname{Veg} a) d \lambda}\right)+0,03
$$

ahol $R_{\mathrm{i}}$ szűrőfüggvény, foton-fluxus egységekben. Ugyanez felírható az AB-magnitúdóra is:

$$
m_{\mathrm{i}}(A B)=-2,5 \log _{10}\left(\frac{\int R_{\mathrm{i}}(\lambda) \lambda F_{\mathrm{v}} d \lambda}{\int R_{\mathrm{i}}(\lambda) \lambda d \lambda}\right)+48,6
$$

A tudományos céllal készült csillagászati képek mindig több különböző szưrőrendszerben készülnek. A fotometriai szúrőrendszereket áteresztési sávszélességük szerint szoktuk osztályozni, hiszen a szúrốk csak bizonyos hullámhosszokon eresztenek át. Vannak keskeny $(\Delta \lambda \simeq 10 \mathrm{~nm})$, közepes $(\Delta \lambda \simeq 30 \mathrm{~nm})$ és széles $(\Delta \lambda \leq 250 \mathrm{~nm})$ sávszélességú szürőrendszerek. A keskeny sávszélességúek általában valamelyik emissziós vonalra vannak centrálva, például a $\mathrm{H} \alpha, \mathrm{H} \beta$ vagy O III vonalra. Ezek általában planetáris ködök, üstökösök alapos megfigyelését teszik lehetôvé. A közepes sávszélességú szűrôrendszerek egyik legismertebb rendszere a Strömgren-féle uvby rendszer. A Strömgren-féle rendszer nagy előnye, hogy szinte spektrofotometrát lehet végezni vele. A (b-y) 


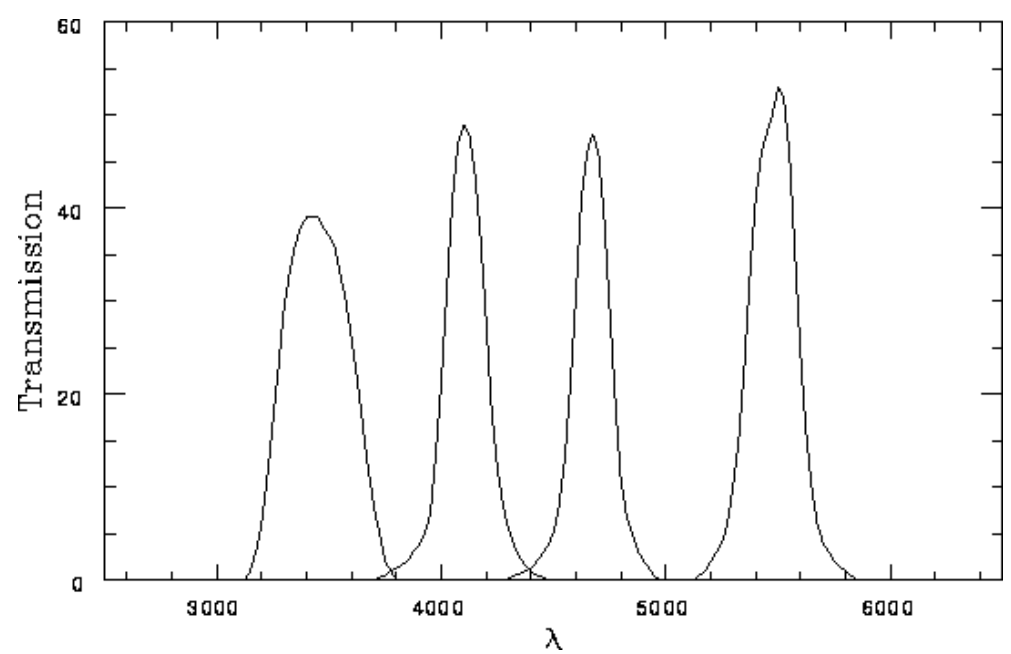

3.1. ábra. A Strömgren-féle uvby szúrők áteresztési függvényei (Crawford \& Barnes, 1970)

színindex arányos a csillag effektív hőmérsékletével, az $m_{1}$ színindex a fémtartalommal korrelál és $c_{1}$ pedig a Balmer-ugrás erősségét jellemzi. A 3.1 táblázat a szűrôk jellemző központi hulláhosszait, illetve az egyes szúrốk sávszélességeit tartalmazza, a 3.1 ábrán a Strömgren-féle szúrők áteresztési függvényei vannak.

3.1. táblázat. A Strömgren-féle uvby rendszer főbb paraméterei

\begin{tabular}{lcc}
\hline Szúró & $\begin{array}{c}\lambda_{0} \\
(\mathrm{~nm})\end{array}$ & $\begin{array}{c}\Delta \lambda \\
(\mathrm{nm})\end{array}$ \\
\hline \hline $\mathrm{u}$ & 350 & 40 \\
$\mathrm{v}$ & 410 & 20 \\
$\mathrm{~b}$ & 470 & 10 \\
$\mathrm{y}$ & 550 & 20 \\
\hline
\end{tabular}

A csillagászatban az egyik legelterjedtebb szúrőrendszer az 1950-es évek óta használt UBV fotometriai rendszer (Ultraviolet, Blue, Visual), amelyet Johnson-rendszernek, Johnson-Morganrendszernek is neveznek. Ez az első ismert szabványosított fotoelektromos fotometriai rendszer, amelyben az U, B és $\mathrm{V}$ betúk az ultraibolya, a kék és a vizuális nagyságrendre vonatkoznak. Ez egy széles sávú fotometriai rendszer, amely többek között a csillagok szín szerinti besorolását teszi lehetôvé. Az évek során további szürôkkel egészült ki a rendszer, így manapság már JohnsonCousins-féle UBVRI rendszerről beszélünk inkább. A 3.2 ábrán a szúrôk áteresztési függvényei láthatóak, míg a 3.2. táblázat a rendszer fontosabb paramétereit tartamazza. Korábban is említettem, hogy ez a rendszer egy tipikus széles sávú szűrôkből álló rendszer, mely csillagok, galaxisok megfigyeléseire alkalmas. A széles sávú szúrôk közé tartozik még az SDSS égboltfelmérő programban használt 5 szûroóből álló SDSS ugriz szűrőrendszer is. Előnye, a Johnson-Cousins-féle szűrőkkel szemben, hogy a szűrôk áteresztési függvényei az SDSS ugriz szúrốk esetén nem fedik át egymást, nem eresztenek át ugyanazon a hullámhosszon. A dolgozatomban felhasznált fénygör- 


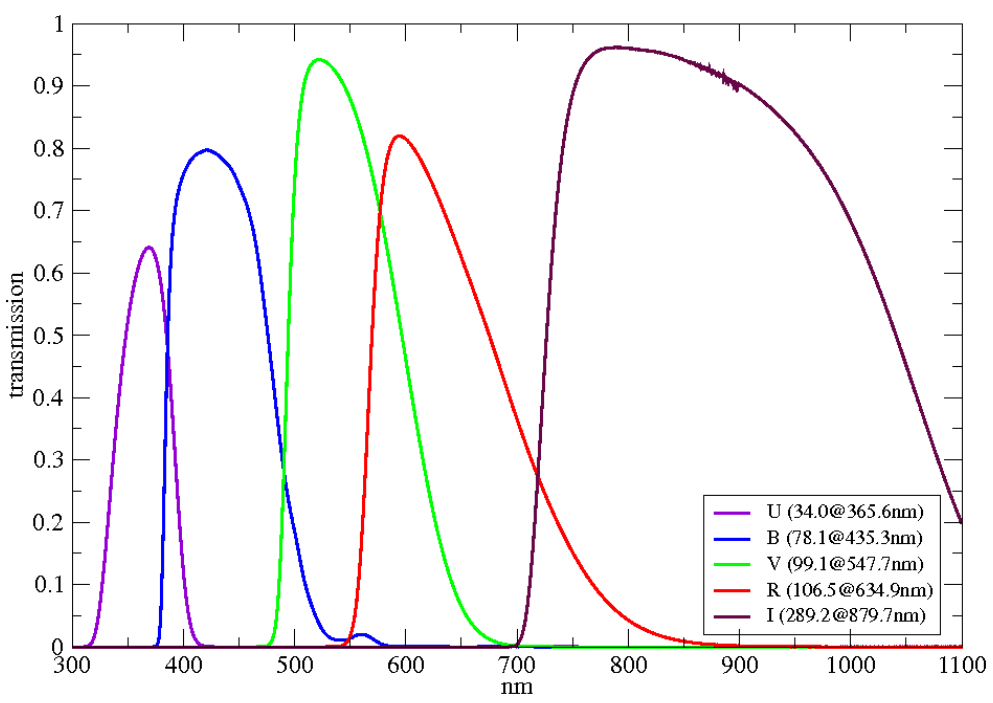

3.2. ábra. A Johnson-Cousins-féle UBVRI szûrốk áteresztési függvényei (http://www.aip.de/ alapján)

bék a Johnson-Cousins-féle szűrőrendszer V, illetve I szűrőivel készültek.

3.2. táblázat. A Johnson-Cousins-féle UBVRI rendszer főbb paraméterei

\begin{tabular}{lcc}
\hline Szúrő & $\begin{array}{c}\lambda_{0} \\
(\mathrm{~nm})\end{array}$ & $\begin{array}{c}\Delta \lambda \\
(\mathrm{nm})\end{array}$ \\
\hline \hline $\mathrm{U}$ & 365 & 70 \\
$\mathrm{~B}$ & 440 & 100 \\
$\mathrm{~V}$ & 550 & 90 \\
$\mathrm{R}$ & 720 & 220 \\
$\mathrm{I}$ & 900 & 240 \\
\hline
\end{tabular}

\subsubsection{Fourier-analízis}

Joseph Fourier, francia fizikus és matematikus, 1807-ben megjelent, Mémoire sur la propagation de la chaleur dans les corps solides címú tanulmányában adta meg azt az algoritmust, amellyel periodikus és nem periodikus jelek diszkrét mintavételezésével is ki lehet számolni az adott jelet alkotó szinuszfüggvényeinek frekvenciáját és amplitúdóját. Az eredeti függvények helyett a hozzájuk tartozó Fourier-sorokat kezdték el vizsgálni.

A Fourier-sor egy folytonos $f(t)$-re, ahol $f(t)$ differenciálható, végtelen hosszú szigorúan periodikus függvény, a következő alakban írható fel:

$$
f(t)=a_{0}+\sum_{\mathrm{k}}\left(a_{\mathrm{k}} \cos \omega_{\mathrm{k}} t+b_{\mathrm{k}} \sin \omega_{\mathrm{k}} t\right)
$$


ahol $a_{0}, a_{\mathrm{k}}$ és $b_{\mathrm{k}}$ valós számok, k pedig egész szám.

A 3.7 egyenletben szereplő $\omega_{\mathrm{k}}$ jelentése:

$$
\omega_{\mathrm{k}}=\frac{2 \pi}{T} k=\omega_{0} k
$$

ahol T a periódusidő. Az $\omega_{0}$-t alapfrekvenciának, az $\omega_{\mathrm{k}}=k \omega_{0}$ tagokat pedig felharmonikusoknak nevezzük.

A Fourier-sor együtthatóinak kiszámítására a következő összefüggések használhatóak:

$$
\begin{gathered}
a_{0}=\frac{1}{T} \int_{-\mathrm{T} / 2}^{T / 2} f(t) d t, \\
a_{\mathrm{k}}=\frac{2}{T} \int_{-\mathrm{T} / 2}^{T / 2} f(t) \cos k \omega_{0} t d t, \\
b_{\mathrm{k}}=\frac{2}{T} \int_{-\mathrm{T} / 2}^{T / 2} f(t) \sin k \omega_{0} t d t .
\end{gathered}
$$

A Fourier-sort olyan alakban is felírhatjuk, amelyben csak egyetlen harmonikus (szinusz, vagy koszinusz) függvény van, de eltérő fázisállandókkal:

$$
f(t)=a_{0}+\sum_{\mathrm{k}} A_{\mathrm{k}} \cos \left(\omega_{\mathrm{k}} t+\phi_{\mathrm{k}}\right)
$$

A 3.12 egyenletben szereplő $A_{\mathrm{k}}$ amplitúdók a (3.9)-ben és (3.10)-ben definiált Fourier-együtthatókkal az alábbi kapcsolatban vannak:

$$
A_{\mathrm{k}}=\sqrt{a_{\mathrm{k}}^{2}+b_{\mathrm{k}}^{2}},
$$

a $\phi_{\mathrm{k}}$ értékei pedig a függvényhez tartozó fázisokat:

$$
\phi_{\mathrm{k}}=\arctan \left(-\frac{b_{\mathrm{k}}}{a_{\mathrm{k}}}\right) .
$$


Általánosabb esetben az $f(t)$ függvényt fel lehet írni a következő integrál alakban is:

$$
f(t)=\int_{-\infty}^{\infty} F(\omega) e^{i \omega t} d t
$$

Az így felírt egyenlet jobb oldalán szereplő integrált nevezzük az adott jel Fourier-integráljának. Ebben az esetben $\omega$ már valós, tetszőleges értékeket felvehet. Nem periodikus jelek esetén az $\omega$ folytonos, így értelmezhetô az $f(t)$ függvény Fourier-transzformáltja:

$$
F(\omega)=\int_{-\infty}^{\infty} f(t) e^{-i \omega t} d t
$$

ahol $f(t)$ valós, $F(\omega)$ komplex függvény. A fenti definíciók értelmében a Fourier-integrál és a Fourier-transzformált végtelen hosszú adatsorok vizsgálatára alkalmas.

Ha nem folytonos, hanem véges, bizonyos időközönként mintavételezett jelünk van, a Fourierintegrált kicsit más formában kell felírnunk. Ha az adatsor teljes időbeli hossza T, akkor (3.15) helyett a következő integrált számítjuk ki:

$$
F(\omega)=\frac{1}{T} \int_{-\mathrm{T} / 2}^{T / 2} f(t) e^{-i \omega t} d t
$$

Ha a jel egyenletes $\Delta t$ időközönként mintavételezett, diszkrét adatsorból áll, akkor a folytonos jelekre vonatkozó (3.16) integrál helyett az alábbi összeget kell kiszámítanunk:

$$
F(\omega)=\frac{1}{T} \sum_{\mathrm{k}=0}^{N-1} f(k) e^{-i \omega t_{\mathrm{k}}} \Delta t
$$

ahol $\Delta t$ a konstans időbeli lépésköz, $f(k)=f\left(t_{\mathrm{k}}\right)$ a függvény $t_{\mathrm{k}}$ időpontban felvett értéke. Ha a mintavételezés egyenletes, akkor $T=N \cdot \Delta t$, ahol $N$ a mérési adatpontok száma.

A (3.17)-ben szereplő $F(\omega)$ az $f(t)$ függvény diszkrét Fourier-transzformáltja . $\Delta t$-t az összegzésből kiemelve, és beírva a $T=N \Delta t$ összefüggést, adódik a DFT irodalomban szokásos alakja (pl. Hesselmann, 1985).

$$
F(\omega)=\frac{1}{N} \sum_{\mathrm{k}=0}^{N} f_{\mathrm{k}} e^{-i \omega t_{\mathrm{k}}}
$$


Az $F(\omega)$ függvény felbontható egy valós és egy képzetes részre:

$$
\begin{gathered}
\operatorname{ReF}(\omega)=\frac{1}{N} \sum_{\mathrm{k}=0^{\mathrm{N}}} f_{\mathrm{k}} \cos \omega t_{\mathrm{k}}, \\
\operatorname{Im} F(\omega)=\frac{1}{N} \sum_{k=0}^{N} f_{\mathrm{k}} \sin \omega t_{\mathrm{k}} .
\end{gathered}
$$

Mindezek alapján egy véges, mintavételezett jel $F(\omega)$ Fourier-spektrumát a valós és képzetes részek kombinációjából képzett $A(\omega)$ amplitúdó- , illetve a $\phi(\omega)$ fázisspektrummal adjuk meg. Ezek definíciója a komplex számok exponenciális reprezentációjához hasonló:

$$
\begin{gathered}
A(\omega)=\sqrt{\operatorname{Re} F(\omega)^{2}+\operatorname{Im} F(\omega)^{2}}, \\
\phi(\omega)=\arctan \left(-\frac{\operatorname{Im} F(\omega)}{\operatorname{ReF}(\omega)}\right) .
\end{gathered}
$$

Az amplitúdóspektrum négyzetét, azaz az $S(\omega)=A^{2}(\omega)$ mennyiséget a jel teljesítménysűrúségspektrumának (vagy az angol szaknyelvből származó terminológiával powerspektrumnak) is nevezik. Az elnevezés eredete a villamosmérnöki gyakorlatból származik: egy váltóáramú villamos jel abszolút értékének négyzete a jel pillanatnyi teljesítményével arányos, ennek egy adott frekvencia körül egységnyi frekvenciaintervallumba esô része a teljesítménysûrúség.

A változócsillagok közül a cefeidák, illetve a nagyamplitúdójú pulzálók fénygörbéi aszimmetrikus lefutásúak. Az ilyen függvények Fourier-sorában az alapfrekvencia mellett a felharmonikusok is megjelennek, a magasabb rendû tagok felé egyre csökkenő amplitúdóval.

A kétmódusú pulzátorok esetén a fényváltozásában az egyidejúleg jelen lévô két rezgési módus miatt még bonyolultabb a helyzet. A cefeida csillagok, pulzáló csillagok fénygörbéjének analíziséről több cikk is megjelent, de először 1981-ben Simon \& Lee adta meg az analízis során használt Fourier-koefficinsek definícióját (Simon \& Lee, 1981).

$$
R_{21}=A_{2} / A_{1}, R_{31}=A_{3} / A_{1}, \phi_{21}=\phi_{2}-2 \phi_{1}, \phi_{31}=\phi_{3}-3 \phi_{1} .
$$

Ezeket a paramétereket használtuk fel mi is a beat cefeidák fénygörbéinek analíziséhez. A Vszúrővel készült fénygörbék leírására a következő egyenletet lehetett ebben az esetben használni: 


$$
\begin{aligned}
m(t) & =m_{0}+\sum_{k=1}^{3} A_{k}(0) \cos \left[k \cdot \frac{2 \pi}{P_{0}} \cdot t+\varphi_{k}(0)\right] \\
& +\sum_{k=1}^{3} A_{\mathrm{k}(1)} \cos \left[k \cdot \frac{2 \pi}{P_{1}} \cdot t+\varphi_{\mathrm{k}(1)]}\right. \\
& +B_{+} \cos \left[2 \pi\left(\frac{1}{P_{1}}+\frac{1}{P_{0}}\right) \cdot t+\varphi_{+}\right] \\
& +B_{-} \cos \left[2 \pi\left(\frac{1}{P_{1}}-\frac{1}{P_{0}}\right) \cdot t+\varphi_{-}\right]
\end{aligned}
$$

az egyenletben szereplő 0 , illetve 1 index az alapmódusra, illetve az első felhangra utalnak. Az egyenlet utolsó két sorára azért van szükség, mert a kétmódusú pulzálók fénygörbéjében az alapmódus és az elsô felhang között fellépő két legerôsebb keresztreakciót (csatolási tagot) is figyelembe kell venni.

\subsubsection{OGLE - Optical Gravitational Lensing Experiment}

Az Optical Gravitational Lensing Experiment (OGLE) projekt egy 25 éve elkezdett, hosszú távú program, amelynek fő célja a Tejútrendszer sötét anyagának mikrolencse jelenségekkel való feltérképezése. A mikrolencse jelenség ezen célra történő alkalmazásának ötletét eredetileg Paczynski javasolta (Paczynski, 1986). Az OGLE program a Varsói Egyetem vezetésével futó csillagászati kutatás. A mikrolencse jelenségeket kutató programok legkézenfekvőbb célterületeinek a Magellán-felhők és a galaktikus dudor (bulge) adódott, az ott jelenlévő háttércsillagok nagy száma miatt. A kutatás első fázisa, az OGLE-I, 1992-től 1995-ig elvégzett méréseket tartalmazza.

Az észlelések a chilei Las Campanas Obszervatórium 1 méteres Swope-távcsövével készültek. A távcsô ezen idôszakban egy 2048x2048 Ford/Loral CCD kamerával volt felszerelve. A projekt során szoros együttmúködésben dolgozott a Varsói Egyetem az amerikai Carnegie Institution of Washington intézettel. Az észlelések nagyon sok tudományos eredményt szolgáltattak. 1996-ban kezdte el múködését a projekt keretein belül az 1,3 méteres Warsaw University Telescope, szintén a Las Campanas Obszervatórium területén. Az OGLE-II fázis hivatalosan 1997-2001 közötti méréseket tartalmazza. Udalski, Kubiak \& Szymański (Udalski, Kubiak \& Szymański, 1997) cikkében egy részletes összefoglalót találunk az OGLE-II során használt múszeregyüttesről.

A dolgozatomban felhasznált mérési eredmények, már az OGLE-III, illetve OGLE-IV fázisban készült felvételek adataiból származnak. Az OGLE-III fázis a 2001-2009 időszakot foglalja magába. Ezt az időszakot a korábban végzett mérésektől azért határoljuk el, mert itt a távcsô már egy második generációs mozaikkamerával volt felszerelve. 8 darab vékony SITe 2048x4096 CCD chipre képződtek le a felvételek, összesen 8192x8192 pixelen, a teljes látómező 35' x 35'. A kamera kiolvasási ideje 98 szekundum, 6-9 e- kiolvasási zajjal, 1,3 e-/ADU érzékelő gainnel. Udalski (Udalski, 2003) összefoglaló cikkében részletesebb leírást találunk a rendszerrôl. Az OGLE-IV 


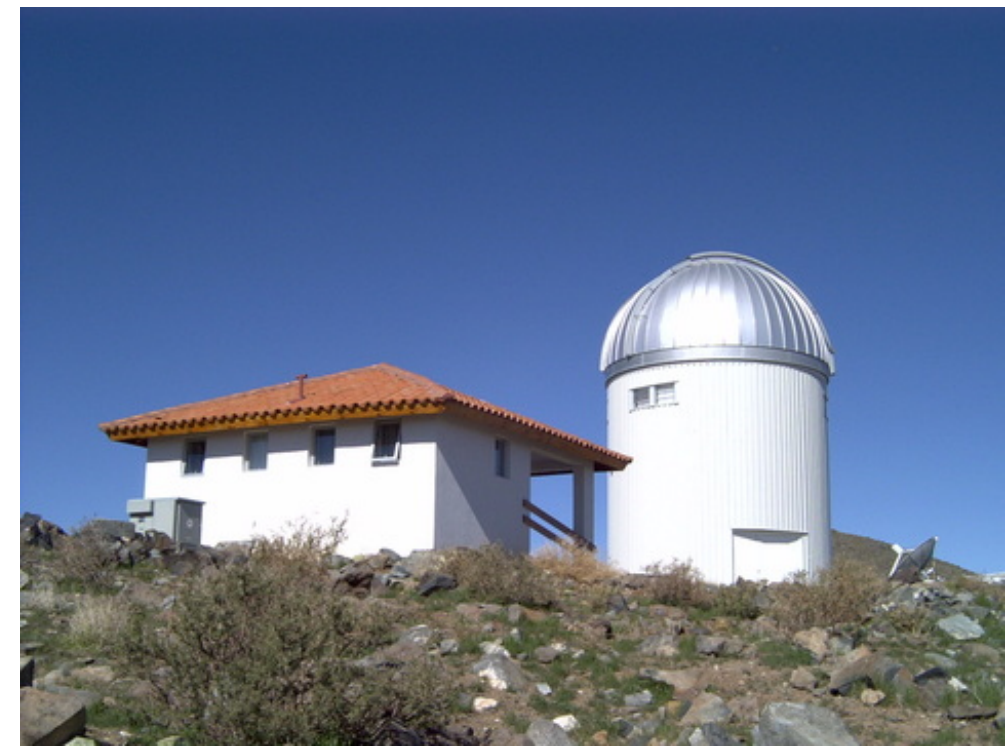

3.3. ábra. Warsaw University Teleszkóp épülete (http://ogle.astrouw.edu.pl/ alapján).

fázisban már harmadik generációs mozaikkamera-rendszer van. 2009-tôl üzemel a 32 vékony E2V44-82 2048x4096 CCD chippel kamera, 1,4 négyzetfokos teljes látómezővel. 4,5-6,5 e- kiolvasási zajjal és 1,0 e-/ADU gainnel. A kamera kiolvasási ideje 20 szekundum. Az OGLE-II és OGLE-III fázisok mérései egy 7 nyílásos $16 \mathrm{~cm}$ átmérôjû automatikusan pozícionálható szûrőváltóval készültek, melyben standard UBVRI szúrốk voltak. Az OGLE-IV már két $31 \mathrm{~cm} \mathrm{x} 31 \mathrm{~cm}$ szúrôt tartalmazó automatikusan pozícionálható szưrôváltóval rendelkezik, melyben standard VI interferometrikus szúrôk vannak installálva. A 3.3. és 3.4. ábrákon az OGLE projekt hivatalos honlapjáról letöltött képeket látjuk a távcsőről és a múszerekről(http://ogle.astrouw.edu.pl/).

\subsection{Spektroszkópia}

\subsubsection{Nagy felbontású echelle-spektroszkópia}

A spektroszkópia az elektromágneses sugárzás hullámhossz szerinti felbontásával és az így keletkezett spektrum rögzítésével foglalkozik. A csillagászati spektroszkópia leginkább az elektromágneses sugárzás optikai tartományára fókuszál. A spektroszkópokat felbontóképességük szerint három csoportba szokás sorolni, kis-, közepes és nagy felbontású spektrográfok. Kis felbontású spektroszkópokat $(R \sim 100-1000)$ használnak például a szupernóva-észlelésekhez, mert bár ezek a spektrumok kis felbontásúak, de nagy hullámhossztartományt fednek le. Közepes felbontású spektroszkópról akkor beszélünk, ha a készülék felbontóképessége $10000 \leq R \leq 20000$ közötti tartományban esik. Az ilyen spektrográfok például a változócsillagok radiális sebességgörbéjének kimérésére alkalmasak. Az eddig említett spektrográfok bontóeleme általában reflexiós optikai rács (3.5. ábra). Egy optikai rendet képeznek le, ami legtöbbször az elsô vagy a második rend. 


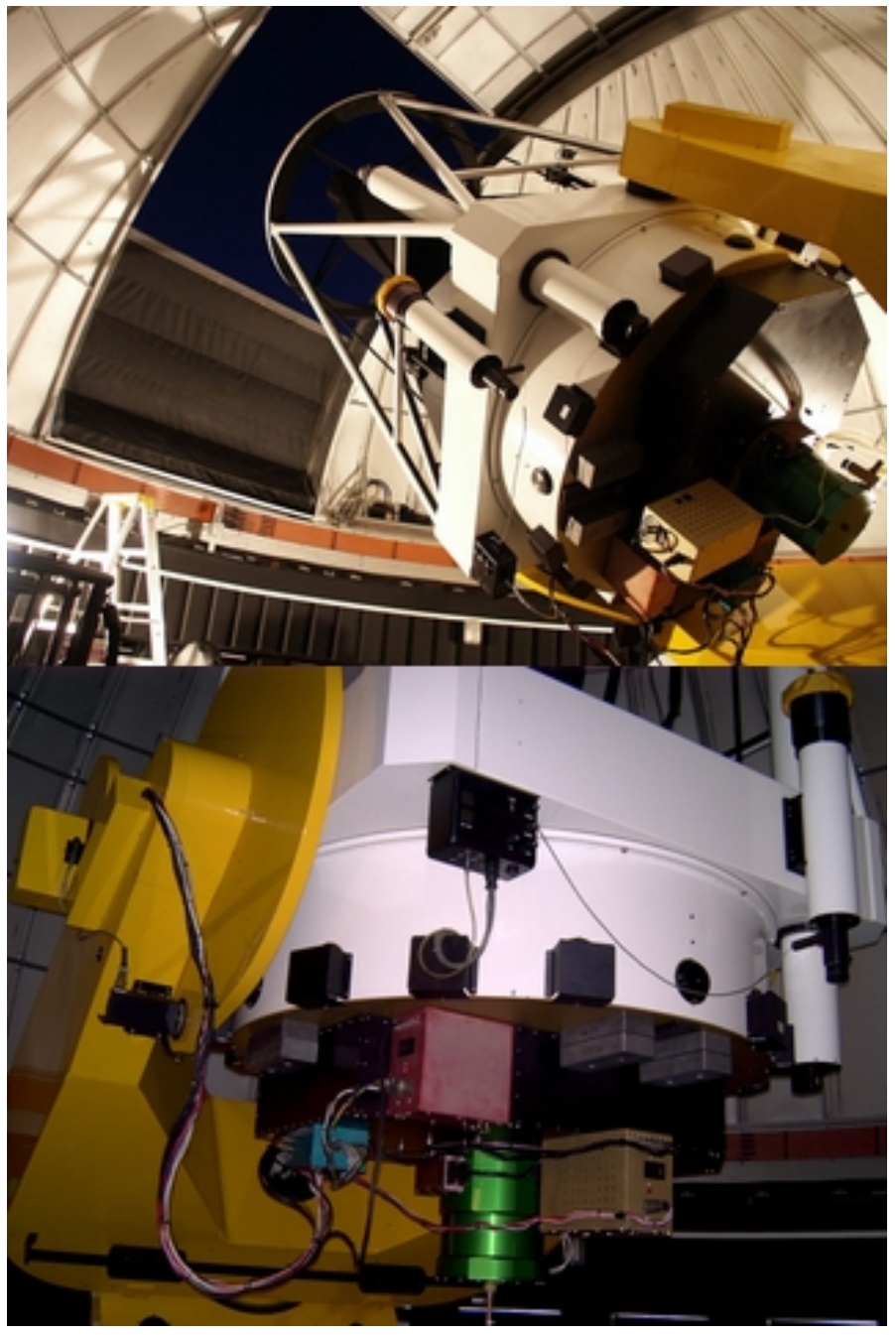

3.4. ábra. Warsaw University Teleszkóp és a múszerei (http://ogle.astrouw.edu.pl alapján). 


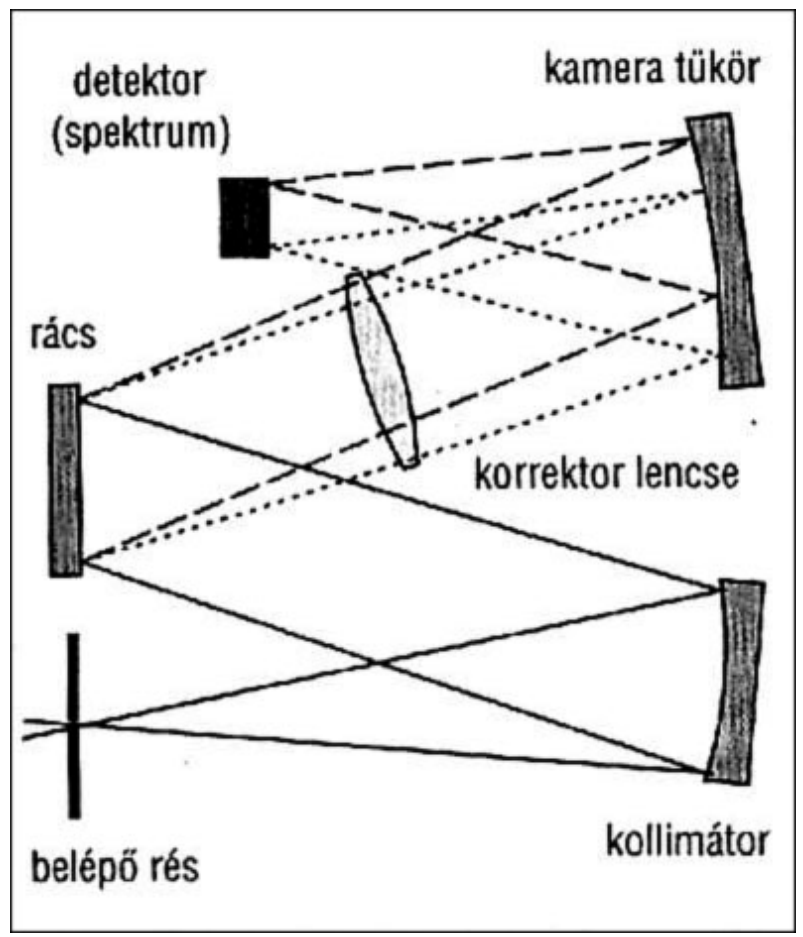

3.5. ábra. A spektrográf elvi elrendezése (http://astro.u-szeged.hu alapján).

A második rendnek az intenzitása kisebb, mint az elsőé, a lefedett hullámhossztartománya viszont nagyobb.

A nagy felbontású spektroszkópiát az 1950-es évek óta használják egyre több helyen csillagászati megfigyelésekre. A nagy felbontású spektrográfok elterjedése lehetôvé tette az exobolygók kimutatását radiális sebességgörbe alapján, illetve a precízebb kémiai analízis is elérhetô lett általuk. Ezeknél a múszereknél a felbontás $R \geq 20000$. A nagy felbontású spektrográfok egyik legelterjedtebb típusa az echelle elrendezés, ami nagy felbontás mellett széles hullámhossztartományt fed le (3.6. ábra). Ezt a spektrográf fő építőeleme teszi lehetôvé, ami egy nagy feloldóképességú, speciális rácsot (ún. echelle rácsot) és egy erre merőleges diszperziós tengelyú második bontóelemet (ami lehet prizma, vagy rács) tartalmaz. Az echelle rács nagy beesési és diffrakciós szög mellett, magas elhajlási rendekben dolgozik (3.7. ábra). Az intenzitás maximuma kb. a 24.-25. rendben van. Mivel az echelle spektrográfok magas rendekben dolgoznak, a szomszédos rendek közötti átfedés nagy, ezért szükséges a rendek térbeli szeparációja. Ez egy másik, ún. keresztdiszperziós elemmel oldható meg, amelynek diszperziós iránya meróleges az echelle rács diszperziós irányára, s így a rendekre merôleges irányban szétválasztja azokat. Attól függóen, hogy ezt a bontóelemet az echelle rács előtt vagy utána helyezik el, pre-, ill. posztdiszperziós elemről beszélünk. A spektrográf által létrehozott színkép kétdimenziós lesz, ezért rögzítésére jól alkalmazhatók a modern kétdimenziós detektorok, régebben képerôsítô csövek, manapság már főként CCD-kamerák. Bár a másodlagos diszpergáló elem fényveszteséget okoz, ezért azonban kárpótol az a tény, hogy az echelle spektrográffal a sok jelenlévő rend miatt nagy hullámhossztartomány fedhetô le egy fel- 


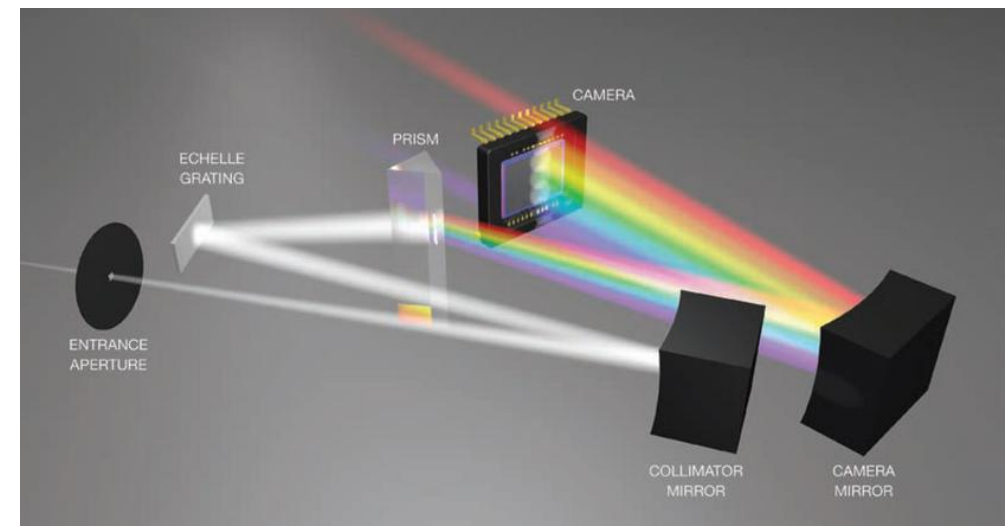

3.6. ábra. Echelle spektrográf (http://rs1.chemie.de alapján).

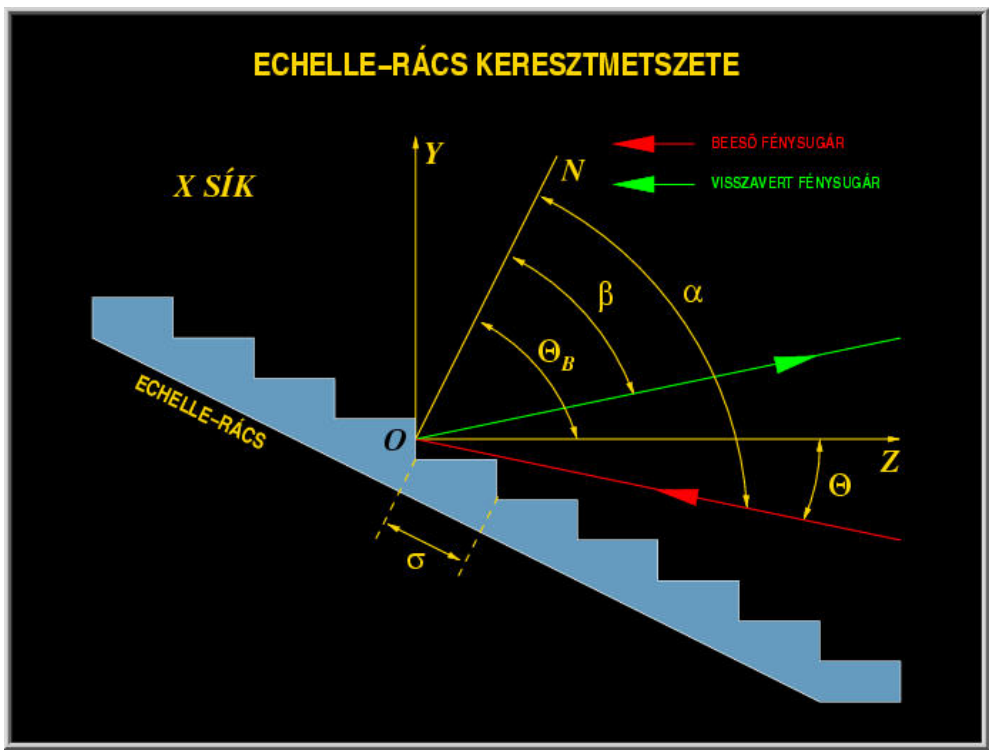

3.7. ábra. Echelle rács oldalnézetből (http://www.gothard.hu/astronomy alapján).

vétellel, ezért alkalmazásával adott észlelési idő mellett jóval több információ gyưjthető össze a megfigyelt objektumról.(http://www.gothard.hu/astronomy/astroteaching/instrumentation/echellespectroscopy/echelle-spectroscopy.php)

A 3.7. ábrán az $\alpha$ a fénysugár beesési szöge, $\beta$ a diffrakciós szög, $\sigma$ a rácsállandó, $\theta_{B}$ pedig az ún. blaze vagy ragyogási szög. Az beesési szög, a diffrakciós szög és a ragyogási szög általában nagyok, míg $\theta$, ami az $\alpha$ és a $\mathrm{Z}$ tengely által bezárt szög kicsi. A tipikus beállítási értékek: $\theta_{\mathrm{B}} \sim$ $60^{0}, \sigma \sim 1 / 30-1 / 300 \mathrm{~mm}, \theta=$ néhány fok.

A 3.7. ábrán látható echelle rács alapegyenlete:

$$
\frac{m \lambda}{\sigma}=\cos \gamma[\sin \alpha+\sin \beta(m)]
$$


ahol $m$ az éppen aktuális elhajlási rend, $\gamma$ a beesô fénysugár és az $X=0$ sík szöge.

Ha az $\alpha$ és a $\beta$ helyére behelyettesítjük a következő kifejezéseket, akkor az egyenlet a 3.28 egyenletre módosul:

$$
\alpha=\theta_{\mathrm{B}}+\theta
$$

$$
\beta=\theta_{\mathrm{B}}-\theta
$$

$$
\frac{m \lambda}{\sigma}=2 \cos \gamma \sin \theta_{B} \cos \theta
$$

Minden rendhez tartozik egy centrális hullámhossz vagy blaze hullámhossz, ami megadja, hogy az adott renden belül hol a legnagyobb az intenzitás. Egyenlettel kifejezve a centrális hullámhossz a következô módon adható meg:

$$
\lambda_{\mathrm{c}}(m)=\frac{2 \sigma \sin \theta_{\mathrm{B}} \cos \theta}{m} .
$$

Fontos jellemzője az echelle rácsnak a szögdiszperzió, ami állandó beesési szög esetén a következő egyenlettel írható fel:

$$
\frac{\beta}{\lambda}=\frac{m}{\sigma \cos \gamma \cos \beta}=\frac{2 \sin \theta_{\mathrm{B}} \cos \theta}{\lambda \cos \left(\theta_{\mathrm{B}}-\theta\right)}
$$

A reciprok lineáris diszperziót a következő képlettel lehet meghatározni:

$$
P=\frac{\sigma \cos \gamma \cos \beta}{m f_{2}}=\frac{\lambda \cos \left(\theta_{\mathrm{B}}-\theta\right)}{2 f_{2} \sin \theta_{\mathrm{B}} \cos \theta},
$$

ahol $f_{2}$ a kamera fókusztávolsága. Az egyik legfontosabb paramétere a spektrográfnak a spektrális felbontás, amit a következő képlet ad meg:

$$
R=\frac{\lambda}{\delta \lambda}=\frac{2 f_{1} \sin \theta_{\mathrm{B}} \cos \theta}{w \cos \alpha}=\frac{d_{1}}{D \Psi} \frac{2 \sin \theta_{\mathrm{B}} \cos \theta}{\cos \alpha}
$$


ahol $f_{1}$ a kollimátor fókusztávolsága, $w$ a belépőrés szélessége, $D$ a távcsô átmérôje, $d_{1}$ a kollimátor átmérője, $\Psi$ pedig a belépő résnek megfelelő szögátmérő az égbolton. A pontosság és az eredmények javítása érdekében az echelle spektrográfokat nem a távcsőre szokták rögzíteni, hanem a távcső és a spektrográf üvegszállal van összekötve. Ez a kivitelezés több előnnyel is jár. Ezzel a módszerrel a spektrográf egy számára kialakított állandó klímájú teremben, szobában lehet a mérések során végig, illetve az üvegszál egy jól meghatározott pontszerú fényforrást biztosít a spektrográf belépó résénél. Az állandó klíma, illetve a múszer azonos pozíciója a nagy diszperzió miatt nagyon fontos, hiszen a nagy diszperzió miatt a múszer nagyon érzékeny a hômérséklet- és pozícióváltozásból eredő mechanikai torzulásokra. A segédtükör zavaró hatása is kiküszöbölhető az üvegszálas szereléssel, mert lehetôség van arra, hogy a távcsố primer fókuszába helyezzük el, nem pedig a Cassegrain-fókuszba.

\subsubsection{Kémiai analízis}

A csillagászati spektroszkópia egyik fő célja, hogy a felvett spektrum alapján az egyes objektumok kémiai összetételéről tudjunk mondani valamit. Ehhez szükség van arra, hogy a spektrumunk színképvonalakat tartalmazzon. Ahhoz, hogy színképvonal keletkezzen, kellő számú olyan részecske szükséges, ami a vonal létrehozásában szerepet játszik, ezen kívül elengedhetetlen a nem túl nagy optikai mélység.

A kémiai összetétel meghatározásában alapvetô szerepet játszó mennyiség a spektrumvonalak ekvivalens szélessége (??. ábra). Az ekvivalens szélesség (EW) matematikai definíciója:

$$
E W=\int_{\Delta \lambda}\left(F_{\mathrm{c}}-F_{\lambda)} / F_{\lambda} d \lambda\right.
$$

ahol $F_{\lambda}$ a $\lambda$ hullámhosszon mért fluxus, $F_{\mathrm{c}}$ a lokális kontinuum fluxusa, és az integrálás a vonal $\Delta \lambda$ hullámhossztartományára terjed ki. Az ekvivalens szélesség az abszorpció erősségét méri, így információt hordoz a kémiai összetételrôl is.

A kémiai analízishez a sugárzás terjedését leíró transzferegyenletet kell megoldani. Ez egy reális csillagot leíró modell-atmoszféra esetén csak numerikusan lehetséges. A lényeget azonban jól szemlélteti az az egyszerú modell, amelyben egy átlátszatlan, feketetest-sugárzó fotoszféra fölött egy részben átlátszó, nem sugárzó, vékony légkör helyezkedik el (Schuster-Schwarzschildmodell). Egy ilyen légkörön keresztül a megfigyelőhöz eljutó fluxus:

$$
F_{\lambda}=F_{0 \lambda} e^{-\kappa \rho h}=F_{0 \lambda} e^{-\kappa_{\mathrm{c}} \rho h} \cdot e^{-\kappa_{1} \rho h},
$$

ahol $h$ a csillaglégkör vastagsága, $\rho$ ennek sûrúsége (ami a légkör vékonysága miatt közel állandónak tekinthetô), $\kappa$ az opacitás, amelyet felbonthatunk a kontinuum folytonos opacitásának és a spektrumvonal opacitásának összegére: $\kappa=\kappa_{\mathrm{c}}+\kappa_{1}$.

Mivel a kontinuum fluxusa $F_{\mathrm{c}}=F_{0 \lambda} e^{-\kappa_{\mathrm{c}} \rho h}$, az ekvivalens szélesség az alábbi integrállal fejez- 
hetô ki:

$$
E W=\int_{\Delta \lambda} 1-\exp \left[-\kappa_{1} \rho h\right] d \lambda=\int 1-\exp \left[-\tau_{1}\right] d \lambda,
$$

ahol $\tau_{1}=\kappa_{1} \rho h$ az optikai mélység a vonal hullámhossztartományán.

A továbbiakban olyan vonalakkal foglalkozunk, amelyek optikailag vékonyak, azaz $\tau_{1}<<1$. Ekkor az exponenciális függvény sorfejtésével, majd a magasabb rendű tagok elhanyagolásával a következő összefüggést kapjuk:

$$
E W=\int 1-\left(1-\tau_{1}\right) d \lambda=\int \tau_{1} d \lambda
$$

Az abszorpciós koefficiensek atomfizikai elméletéből a vonalas abszorpciót a 3.37. egyenletben felírt módon lehet kifejezni. A számítások részletes leírása megtalálható C. Dullemond: Radiative transfer in astrophysics ${ }^{1}$ c. kurzusának anyagában.

$$
\kappa_{\mathrm{l}} \rho=\frac{\pi e^{2}}{m c} \frac{\lambda^{2}}{c} f_{\mathrm{ij}} N_{\mathrm{i}} \phi(\lambda),
$$

ahol $f_{\mathrm{ij}}$ az adott átmenetre vonatkozó oszcillátorerôsség, $N_{\mathrm{i}}$ a vonalat létrehozó atomi átmenet alsó szintjének betöltöttsége, $\phi(\lambda)$ pedig a vonalprofil alakját leíró (egyre normált) függvény. $\phi(\lambda)$ konkrét alakja a vonalkiszélesedési mechanizmusoktól függ: termikus (Doppler-) kiszélesedés esetén gaussi-, nyomási kiszélesedés esetén lorentzi alakú. Esetünkben azonban a vonalprofil konkrét alakja lényegtelen, mivel az ekvivalens szélesség kiszámításakor úgyis kiintegráljuk.

Ha feltesszük, hogy a légkörben lokális termodinamikai egyensúly (LTE) uralkodik, az atomi szintek betöltöttségét a Boltzmann-formula adja meg:

$$
\frac{N_{\mathrm{i}}}{N}=\frac{g_{\mathrm{i}}}{z(T)} \exp \left[-\frac{\varepsilon_{i}}{k T}\right]
$$

ahol $N$ az adott kémiai elem (adott ionizációs állapotához tartozó) összes atom száma egységnyi térfogatban, $g_{\mathrm{i}}$ az i-edik állapot statisztikus súlya, $z(T)$ az állapotösszeg (partíciós függvény), $\varepsilon_{\mathrm{i}}=E_{\mathrm{i}}-E_{0}$ az adott állapot és az alapállapot közti energiakülönbség (gerjesztési potenciál), $T$ a hőmérséklet.

Mindezeket behelyettesítve a 3.36. egyenletbe, minden tag kiemelhetô az integráljel elé, kivéve a vonalprofilt, amelynek $\lambda$ szerinti integrálja viszont 1 -et ad. Így végül az ekvivalens szélességre az alábbi kifejezés adódik:

$$
\frac{E W}{\lambda}=\frac{\pi e^{2}}{m c} \frac{\lambda g_{\mathrm{i}} f_{\mathrm{ij}}}{z(T)} \cdot N h \cdot \exp \left[-\frac{\varepsilon_{\mathrm{i}}}{k T}\right]
$$

Látható, hogy optikailag vékony vonalakra az ekvivalens szélesség az atomok koncentrációjának lineáris függvénye. Az atomfizikai paraméterek, valamint a hőmérséklet ismeretében az

\footnotetext{
${ }^{1}$ http://www.ita.uni-heidelberg.de/ dullemond/lectures/radtrans_2012/index.shtml
} 
ekvivalens szélességek mérésével így elvileg meghatározható az adott kémiai elem koncentrációja, és ezen keresztül a kémiai összetétel.

Optikailag vastag (erős) vonalak esetén a 3.39 egyenlet érvényét veszti, ilyenkor az ekvivalens szélességek a koncentrációtól bonyolultabb, nemlineáris módon függenek. Az ilyen vonalak sokkal érzékenyebbek az LTE feltétel sérülésére, azaz a nem-LTE (NLTE) viszonyokra is. Ezért a kémiai összetétel mérésénél törekedni kell a minél gyengébb vonalak használatára.

A gyakorlatban nem közvetlenül a koncentrációkat, hanem azok hidrogénhez viszonyított arányát, azaz az ún. gyakoriságot $\left(A_{\mathrm{X}}=N_{\mathrm{X}} / N_{\mathrm{H}}\right)$ adják meg. A tapasztalat azt mutatja, hogy a csillagok hidrogéntartalma nem változik jelentősen csillagról csillagra, ezért megállapodás szerint a Nap hidrogéntartalmát $\log N_{\mathrm{H}}=12$-nek választják. Ezt felhasználva egy adott elem abszolút logaritmikus gyakoriságát (abundanciáját) a $\log a_{\mathrm{X}}=\log A_{\mathrm{X}}+12$ képlettel adják meg.

Szintén a gyakorlatban használatos paraméter az ún. fémesség, amely egy adott elem relatív gyakoriságának logaritmusát a Naphoz viszonyítja, azaz $[\mathrm{E} / \mathrm{H}]=\log \left(N_{\mathrm{E}} / N_{\mathrm{H}}\right)-\log \left(N_{\mathrm{E}} / N_{\mathrm{H}}\right)_{\odot}$. Csillagok esetén a fémességet legtöbbször a vas relatív gyakoriságával fejezik ki, ez a relatív vastartalom $([\mathrm{Fe} / \mathrm{H}])$. Galaxisok esetén viszont méréstechnikai okokból a fémességet inkább az $[\mathrm{O} / \mathrm{H}]$ paraméterrel jellemzik. 


\section{4. fejezet}

\section{Célkitúzések}

Doktori munkám során célul tûztem ki az egyszerre két módusban pulzáló beat cefeidák fémtartalma és pulzációs tulajdonságai közti összefüggések tanulmányozását. Nagy motivációt adott a téma kiválasztásában, hogy a tapasztalati és az elméleti modellek is azt sejtették, hogy a pulzáció jellege nagyban függ a csillag fémtartalmától. Ennek az összefüggésnek a meglétét, valószínúségét többen is felvetették korábban a cikkeikben, de senki nem vizsgálta konkrétan.

A galaktikus beat cefeidák még elegendően fényesek ahhoz, hogy kellően nagy távcsővel nagy felbontású spektroszkópiai mérésekből közvetlen fémtartalmakat határozzunk meg. Ennek érdekében 2004-ben külföldi együttmúködő partnerünk közremúködésével méréseket végeztünk az Európai Déli Obszervatórium (ESO) chilei La Silla Obszervatóriumának 2,2 méteres távcsövére szerelt FEROS nevú nagy felbontású echelle-spekrográffal. A mérés eredményeként a 23 ismert beat cefeidából 17 olyan csillagról készítettünk spektrumokat, amelyekből 4-et korábban csak fotometriai módszerekkel vizsgáltak. Ezen mérések kiértékeléséből a beat cefeidák fémtartalmának és periódusarányának (korábban elméleti úton felismert) összefüggését igyekeztem pontosítani.

Az így kapott eredményeim felhasználásával részletesebben megvizsgáltam a Nagy- és KisMagellán-felhők kétmódusú cefeidáit, különös tekintettel a fénygörbék Fourier-paraméterei és a fémtartalom közti összefüggésekre. Ennek érdekében összegyújtöttem az irodalomból ismert fotometriai és spektroszkópiai adatokat. A Fourier-analízis alkalmazásával meghatároztam a fénygörbék alakját jellemző amplitúdó- és fázisarányokat, majd korrelációkat kerestem ezen Fourierparaméterek és a korábbi eredményeimből származó fémtartalmak között. 


\section{5. fejezet}

\section{Mérések és alkalmazott módszerek}

\subsection{Spektrumok redukálása}

A dolgozat első, illetve második tézispontjának alapjait szolgáltató spektroszkópiai megfigyelések az ESO tulajdonában lévő MPG 2,2 méteres tükörátmérőjú távcsövére szerelt nagy felbontású FEROS (Fiber-fed Extended Range Optical Spectrograph) echelle spektrográffal készültek. Ez a teleszkóp a chilei La Silla-ban található (Kaufer et al., 1999). Az 5.1. ábrán a teleszkóp kupolája, illetve a FEROS spektrográf fényképe látható.

A spektrográf 3900 és 9200 hullámhossztartományon folyamatos lefedettségú spektrum felvételére alkalmas, $\mathrm{R}=48000$ felbontóképesség mellett . Két optikai szálas rendszer, ami azt jelenti, hogy az objektumról és az objektumhoz közeli égboltról egyszerre, egyidőben készül spektrum. Detektorként egy $15 \mu$ m-es 2148 x 4096 felbontású CCD-kamera volt felszerelve, amikor az általunk felhasznált mérések készültek. Tizenhét beat cefeidát választottunk ki az ismert déli galaktikus kétmódusú cefeidák közül megfigyelési célpontként. A kiválasztott csillagok adatait az 5.1. táblázat tartalmazza. Ez a méréssorozat azért volt nagy jelentőségú, mert kétmódusú cefeidákról korábban nem készült nagy felbontású spektrum.
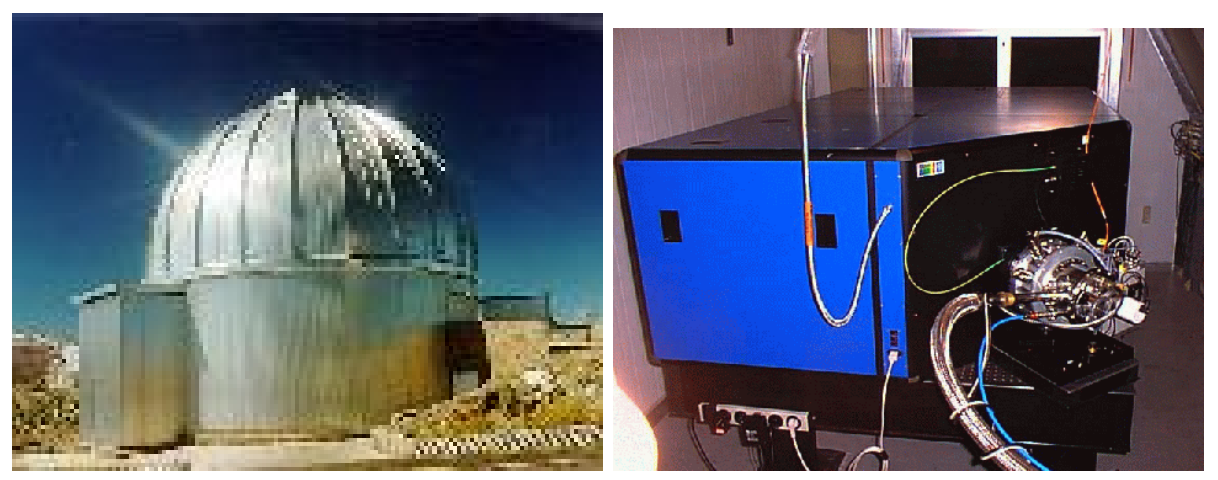

5.1. ábra. MPG 2,2 méteres tükörátmérőjú távcső kupolája és a hozzá tartozó FEROS echelle spektrográf. 
5.1. táblázat. A programcsillagok főbb paraméterei. Referencia: A: Antipin (1997); BP: Beltrame, Poretti (2002); PP: Pardo, Poretti (1997); WO: Wils, Otero (2004).

\begin{tabular}{|c|c|c|c|}
\hline Csillag & $P_{0}($ nap) & $P_{1} / P_{0}$ & Referencia \\
\hline Y Car & 3,6398 & 0,7032 & PP \\
\hline EY Car & 2,8760 & 0,7079 & WO \\
\hline GZ Car & 4,1589 & 0,7054 & PP \\
\hline $\mathrm{TU} \mathrm{Cas}^{a}$ & 2,1393 & 0,7097 & PP \\
\hline UZ Cen & 3,3343 & 0,7064 & PP \\
\hline BK Cen & 3,1739 & 0,7004 & PP \\
\hline VX Pup & 3,0118 & 0,7104 & PP \\
\hline EW Sct & 5,8235 & 0,6986 & PP \\
\hline V367 Sct & 6,2932 & 0,6968 & PP \\
\hline V458 Sct & 4,8412 & 0,6993 & A \\
\hline BQ Ser & 4,2710 & 0,7052 & PP \\
\hline $\mathrm{U} \operatorname{Tr} \mathrm{A}$ & 2,5684 & 0,7105 & PP \\
\hline AP Vel & 3,1278 & 0,7033 & PP \\
\hline AX Vel & 3,6732 & 0,7059 & PP \\
\hline GSC 8691-1294 & 4,317 & 0,7035 & WO \\
\hline GSC 8607-0608 & 4,089 & 0,7017 & WO \\
\hline V1048 Cen $^{b}$ & 0,9224 & 0,8058 & $\mathrm{BP}$ \\
\hline
\end{tabular}

A csillagokról 2004. május 30. és június 1. között 3 éjszaka készültek spektrumok, a méréseket együttmúködő partnerünk, Ennio Poretti készítette. A spektrumok kiolvasása úgynevezett "normál" módban történt, a kiolvasási idő: 41,6 s, az érzékelő gain: 3,2 e-/ADU, és a kiolvasási zaj 5,1 e- volt ebben a módban. Az expozíciós időtartamokat elsősorban a célcsillag fényessége alapján választottuk meg, de ügyeltünk arra is, hogy túlzottan hosszú expozíciós idô se legyen szükséges, mert hosszabb idő alatt a csillagok paraméterei esetleg megváltozhatnak a pulzációjuk miatt. A spektrumok kalibrációjához szükséges adatok, ezalatt a bias, a dark, a flat-field és a ThArNe lámpa felvételeire gondolok, a standard kalibrálási rutinnal készítették a mérés során. Sőt, minden nap több Nap-spektrumot is rögzítettek sötétedés elôtt ugyanazzal a beállítással, amivel aztán az éjszaka folyamán a csillagok spektrumát vették fel. Az 5.2. ábrán a FEROS által készített nyers objektum spektrum látható.

Az 5.1. táblázatban szereplő déli programcsillagok mellett, megtalálható az északi beat cefeidák közé sorolható TU Cas csillag két echelle spektruma is. Ezek a spektrumok a kanadai David Dunlap Obszervatórium 188 cm-es távcsőre felszerelt echelle spektrográffal készültek 1997-ben. A múszer pontosabb adataira, illetve a redukálás menetére itt nem térek ki bôvebben, mert a spektrumokat már kiredukálva kaptam meg, ha szükséges ezek leírása Kiss \& Vinkó 2000-es cikkében megtalálhatóak.

A FEROS által készült spektrumok két egymástól független módon lettek kiredukálva. A IRAF 


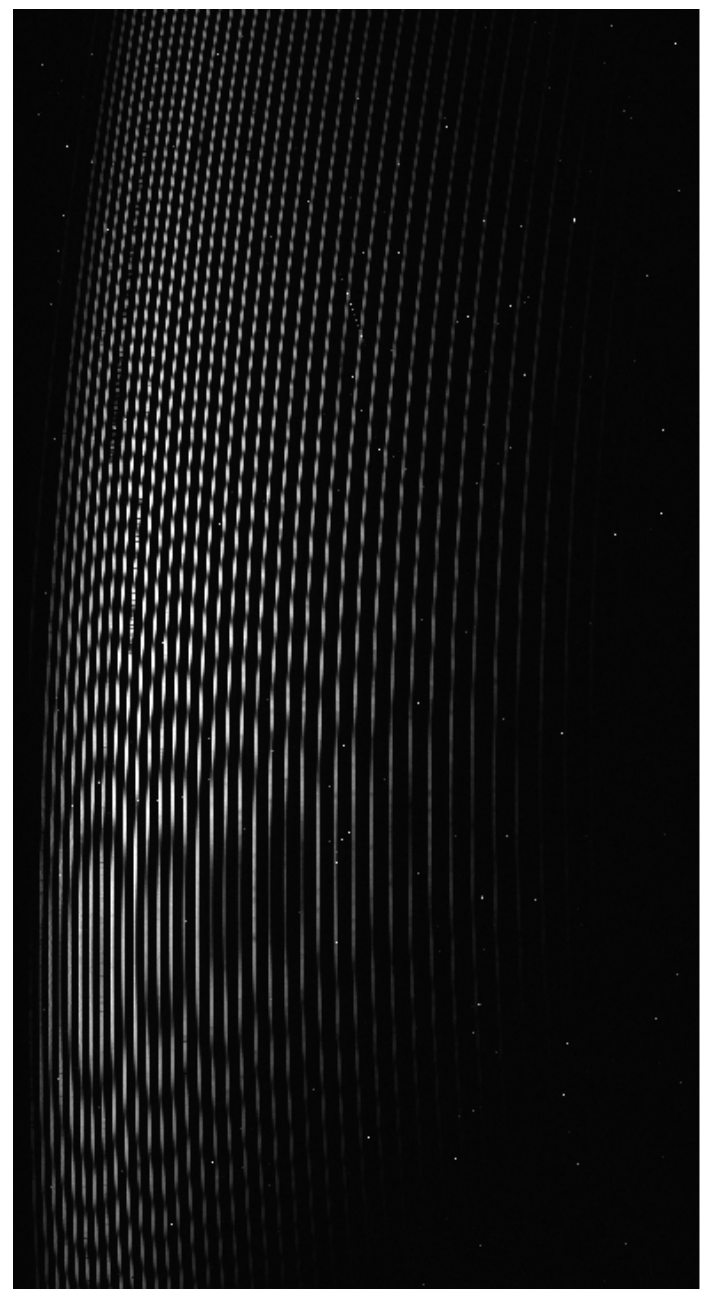

5.2. ábra. FEROS spektrográffal készült "nyers" spektrum. 
programcsomag segítségével, illetve az ESO által megadott MIDAS pipeline-nal. A kiértékelés során az interaktív redukálást helyeztem előtérbe annak érdekében, hogy alaposan ellenőrizni tudjam a program által végzett egyes lépéseket, ezzel elkerülendô, hogy az eredményül kapott spektrumok esetlegesen rosszul legyenek kalibrálva, illetve bármilyen redukálásból származó téves információt tartalmazzanak.

A következőekben részletesebben bemutatom a redukálás egyes lépéseit. A spektrumok felvételei CCD kamerával készültek, ezért ezek a képek a detektor sajátosságaiból származó hibákkal terheltek, melyek a mérések pontosságát nagymértékben csökkentik. Legelőször ezek korrekciójára van szükség. Az egyik a bias korrekció, a másik pedig a flatfield korrekció, amit a CCD technikával készített képeken minden esetben el kell végezni, függetlenül attól, hogy fotometriai vagy spektroszkópiai jellegú felvételeket készítettünk.

Bias korrekció esetén a detektor nulla expozíciós időhöz tartozó alap jelszintjét korrigáljuk ki, hiszen a detektor fénymentes, sötét környezetben, nulla expozíciós idő esetén is mutat jelszintet. Ez a "hiba" mindig additív tagként jelenik meg a képeken, amit ezért a felvételekbôl feltétlenül le kell vonni. Matematikai alakban felírva a következő múveletet kell elvégeznünk:

$$
I^{\prime}(x, y)=I(x, y)-\frac{\sum_{\mathrm{p}=1}^{M} B_{\mathrm{p}}(x, y)}{M},
$$

ahol $I(x, y)$ a korrigálni kívánt, $I^{\prime}(x, y)$ a korrigált kép egyes pixeleinek intenzitása, $B_{\mathrm{p}}$ a p-edik bias kép egyes pixeleinek intenzitása. Az egyenletben több bias kép átlaga van feltüntetve, mert a bias felvételekre a kiolvasó elektronika random kiolvasási zaja is rárakodik, az ebből származó szórás pedig csak több felvétel átlagolásával csökkenthető. Ezt figyelembe véve első lépésként az összes felvételt bias-korrigáltuk egy átlagolt bias felvétel kivonásával. Az átlagolt bias felvételt a "normál" kiolvasási módban készített bias képek átlagából határoztuk meg.

Miután a bias korrekció elkészült, szükséges volt beépíteni egy plusz korrekciós lépést mielőtt a flat-korrekcióra áttértünk volna. A csillagokról készült képekről el kellett távolítani a véletlenszerúen a felvételekre kerülő kozmikus sugarakat. Ezek a világűrből érkező nagy energiájú részecskék a detektor fényérzékelő felületén akár több pixelben is sok elektront válthatnak ki. A felvételeken így nagyon nagy intenzitású pontok, vonalak jelennek meg, melyek a méréseket szintén nagy mértékben megzavarják. Mivel ezek a kozmikus sugarak általában jól megkülönböztethetőek a tényleges, hasznos információt hordozó beütésektől, így különválasztásuk és eltüntetésük a környezet átlagos intenzitásának behelyettesítésével viszonylag egyszerúen elvégezhető. Ezt a lépést végzi el az IRAF noao.imred.crutil.cosmicrays taszkja, természetesen interaktívan és nagy körültekintéssel lefutatva, nehogy olyan részek is korrigálásra kerüljön a felvételeken, amelyek nem kozmikus sugártól származnak. 
A bias korrekció és a kozmikus sugarak korrekciója után lehetett elkészíteni egy átlagolt flatfield képet, amellyel a flatfield-korrekció elvégezhető. A flatfield korrekcióra azért van szükség a CCD technikánál, mert a kamera egyes pixeleinek érzékenysége más és más, valamint az egyéb fényútban levő optikai elemek felületén megjelenő szennyeződések hatására a keletkezett kép intenzitás viszonyai nem egyeznek meg az eredtileg leképezésre kerülő terület intenzitás eloszlásainak. Ehhez a korrekcióhoz úgynevezett flatfield képet kell készíteni. Képalkotás esetén a flatfield kép általában valamilyen homogén megvilágítású felületről készül, pl. a derült, szürkületi égboltról. A spektroszkópiai flatfield azonban ettől különbözik: itt a spektrográf belépô rését kell egyenletesen kivilágítani. Erre általában egy jó közelítéssel feketetest-sugárzást kibocsátó speciális lámpát használnak, így történt ez a mi esetünkben is. Az átlagolt flatfield képet szintén bias korrigálni kell, majd egyre normálni, és végül a korrigálni kívánt képet ezzel kell elosztani. A flatfield korrekció lépései képletbe foglalva:

$$
\begin{gathered}
F(x, y)=\frac{\sum_{\mathrm{i}=1}^{N} F_{\mathrm{i}}(x, y)}{N}-\frac{\sum_{\mathrm{p}=1}^{M} B_{\mathrm{p}}(x, y)}{M} \\
I^{\prime \prime}(x, y)=\frac{I^{\prime}(x, y)}{F(x, y)} \cdot \frac{\sum_{\mathrm{x}, \mathrm{y}=1}^{j, k} F(x, y)}{j \cdot k}
\end{gathered}
$$

ahol $F_{\mathrm{i}}(x, y)$ az egyes flat-field képek pixeleinek intenzitása, az $F(x, y)$ pedig az átlagolt flat-field kép pixeleié. $I^{\prime}(x, y)$ a bias-, $I^{\prime \prime}(x, y)$ a bias és flat-korrigált kép pixeleinek intenzitása. A flatfield képek esetén a kozmikus sugarak okozta hamis, magas számtani értékek medián átlagolással szépen kiküszöbölhetőek. Az 5.3. ábrán a FEROS spektrográffal készült bias-, illetve flatfield kép látható.

A flatfield képek a spektrum redukálásnál a flatfield korrekción kívül az egyes echelle-rendek azonosítását is lehetôvé teszik. Mivel az echelle-rendek fluxus profilja bonyolult kettôs csúcsú rajzolatot mutatnak, ráadásul változatos formában az egész chipen, ezért IRAF beépített automatikus rend felismerô algoritmusa ezeknél a spektrumoknál egyáltalán nem bizonyult megbizhatónak. Így az összes spektrális rendet egyesével, vizuálisan azonosítottuk, majd meghatároztuk a rendek helyzetét, illetve a hozzájuk tartozó apertúraszélességet. Az 5.4. ábra néhány apertúra helyzetének és szélességének meghatározása mutatja be, illetve egy rend követését, illetve illesztését szemlélteti.

Megbízhatóan összesen 70 rendet tudtunk meghatározni, 35-öt a csillagra, és 35-öt az égboltra. Ezek után a redukálást két egymástól független úton folytattuk. Az elsô esetben, a noao.imred.echelle.dofoe taszkot használtuk, amely alapvetően a két optikai szálas spektrumok redukálására lett kifejlesztve. Ez egy komplex, összetett taszk, amely elvégzi a szórtfény-levonást, megkeresi a rendeket egy referencia kép alapján, megcsinálja flatfield korrekciót és végül elvégzi a hullámhossz-kalibrálást a spektrállámpa felvétele alapján. 


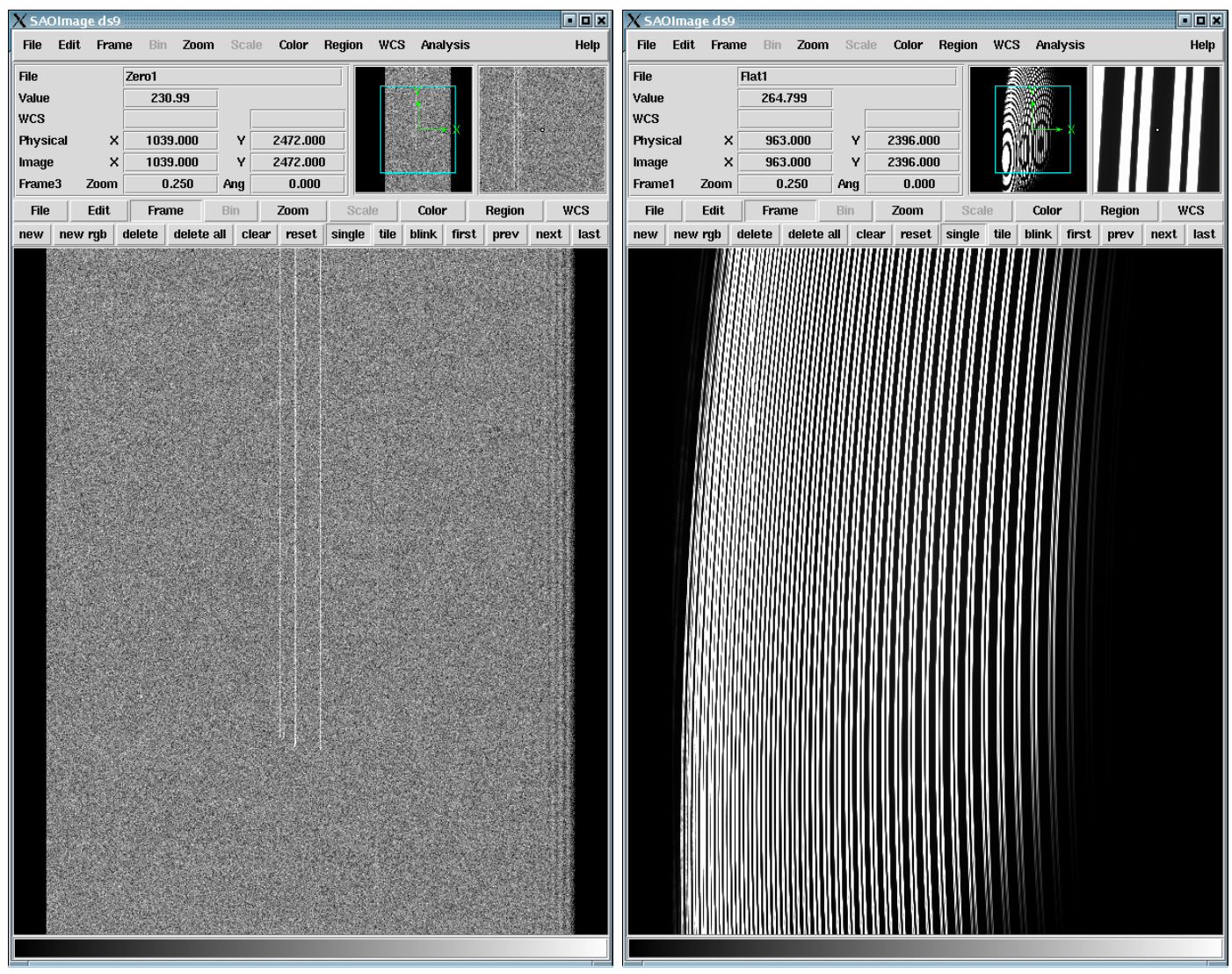

5.3. ábra. FEROS spektrográffal készült bias-, illetve flatfield kép.
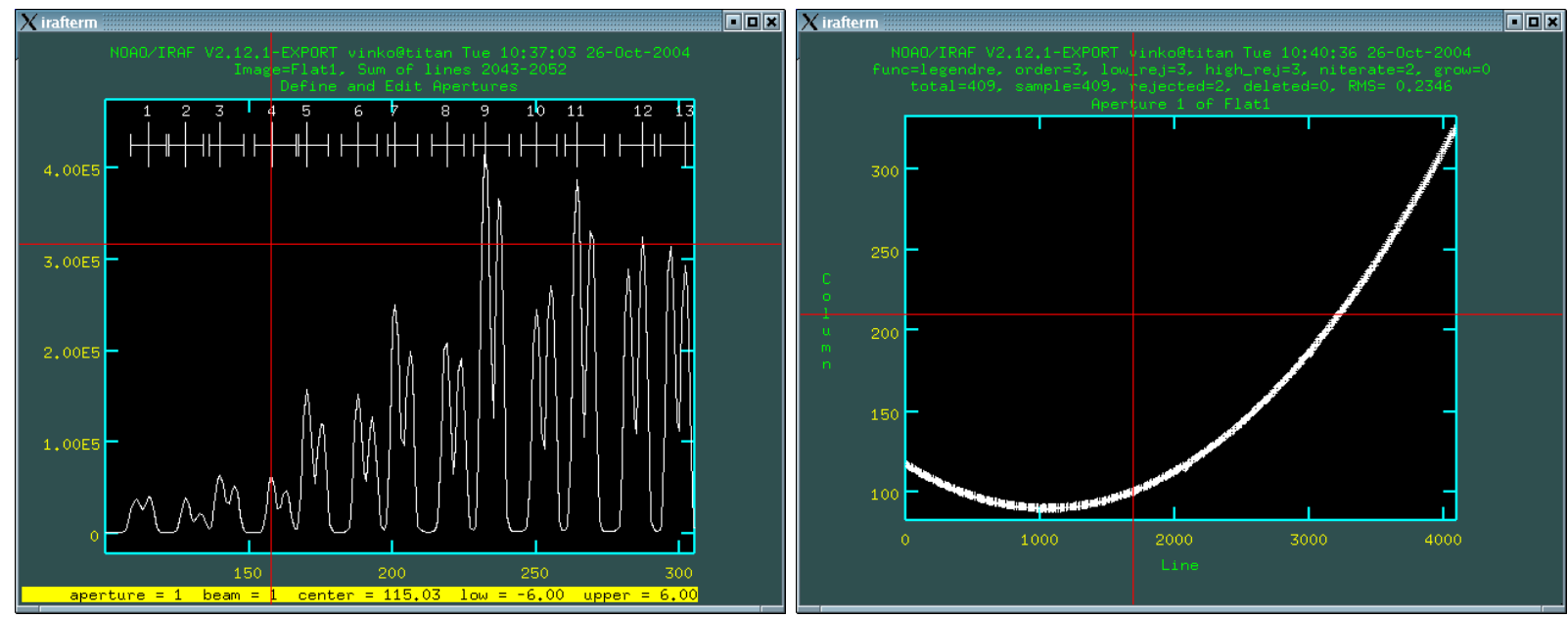

5.4. ábra. Néhány apertúra helyzetének és szélességének meghatározása, illetve egy rend követése, valamint a rend megillesztése. Jól látszik az említett kettôs csúcs a fluxus profilban. 

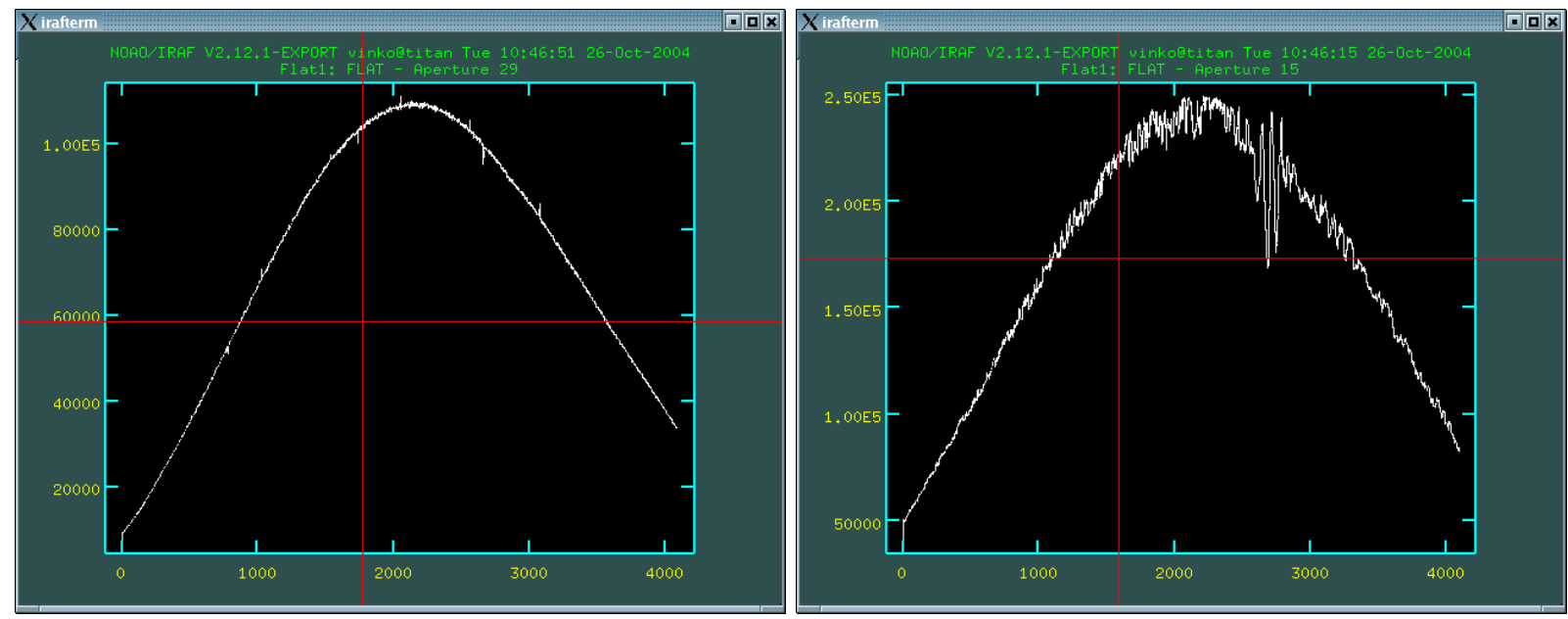

5.5. ábra. Rendek kiintegrálása a diszperziós tengely mentén.

A rendek megkereséséhez referenciaképként a fentebb leírtak alapján előkészített flatfieldképet használtuk fel ebben az esetben. A kinyert flatfield rendeket egy sima polinommal megillesztettük, amely csak a pixelről-pixelre való változásokat vette figyelembe, majd ezt az úgynevezett "maradék" flatfield képet használtuk fel később a képek flatfield korrekciójához.

Az apertúrák helyzetének meghatározása után az egyes rendek követése és illesztése következett. Az illesztést a következő polinommal valósítottuk meg:

$$
m=\sum_{\mathrm{i}=0}^{2} a_{\mathrm{i}} x^{i}
$$

Az 5.5. és az 5.6. ábrák a rendek kiintegrálását szemléltetik a diszperziós tengely mentén.

Ez a fajta flatfield korrekció nem veszi figyelembe a spektrumok blaze-függvényét, amelyet később ezért még meg kellett határozni és el kellett távolítani a spektrumokból. Ez a lépés végül a spektrum kontinuum-normálása során történt meg.

A hullámhossz-kalibráláshoz egy "master" képet hoztunk létre, melyet több hosszú- és rövid expozíciós idejú spektrállámpa felvétel medián átlagolásával képeztünk. Erre azért volt szükség, mert a rövid expozíciós idejú felvételeken sok a gyenge, keskeny vonal a spektrumban, de kicsi a jel/zaj viszony, míg a hosszú expozíciós idônél már sok vonal megy telítésbe (5.7. ábra).

Az átlagolt spektrállámpa spektrumot ezért úgy állítottuk elő, hogy a lehetô legtöbb gyenge vonal legyen rajta jó jel/zaj értékkel, illetve a lehető legkevesebb telített erôs vonal legyen benne. A FEROS stabilitása lehetővé tette számunkra, hogy ezt az egyetlen átlagolt spektrállámpa képet használjuk a hullámhossz-kalibráláshoz minden objektum spektrumához, amelyek ugyanazon estén készültek. A hullámhossz-kalibrálást a dofoe taszk segítségével végeztük el, ami egy kétdimenziós polinomiális illesztést csinál az egyes rendek számára és a kalibráló emissziós vona- 

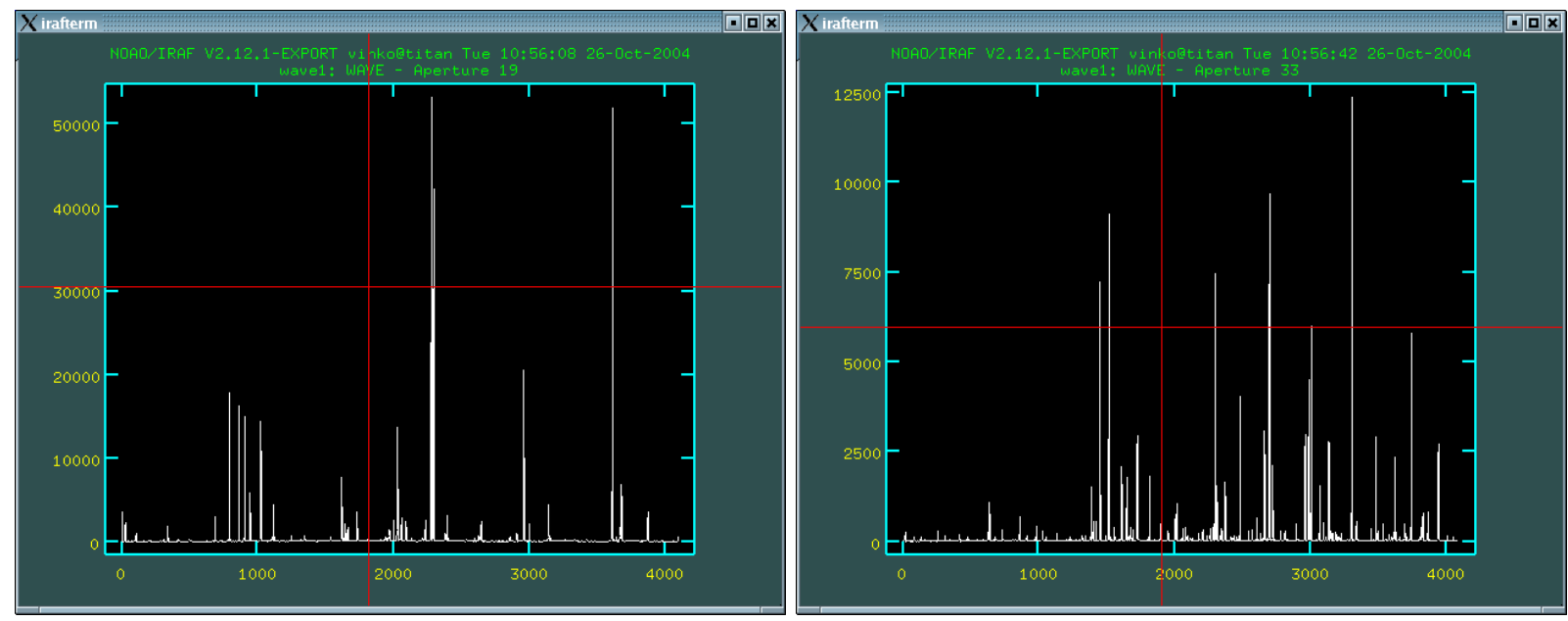

5.6. ábra. Rendek követése és kiintegrálása a spektrállámpa képeken.
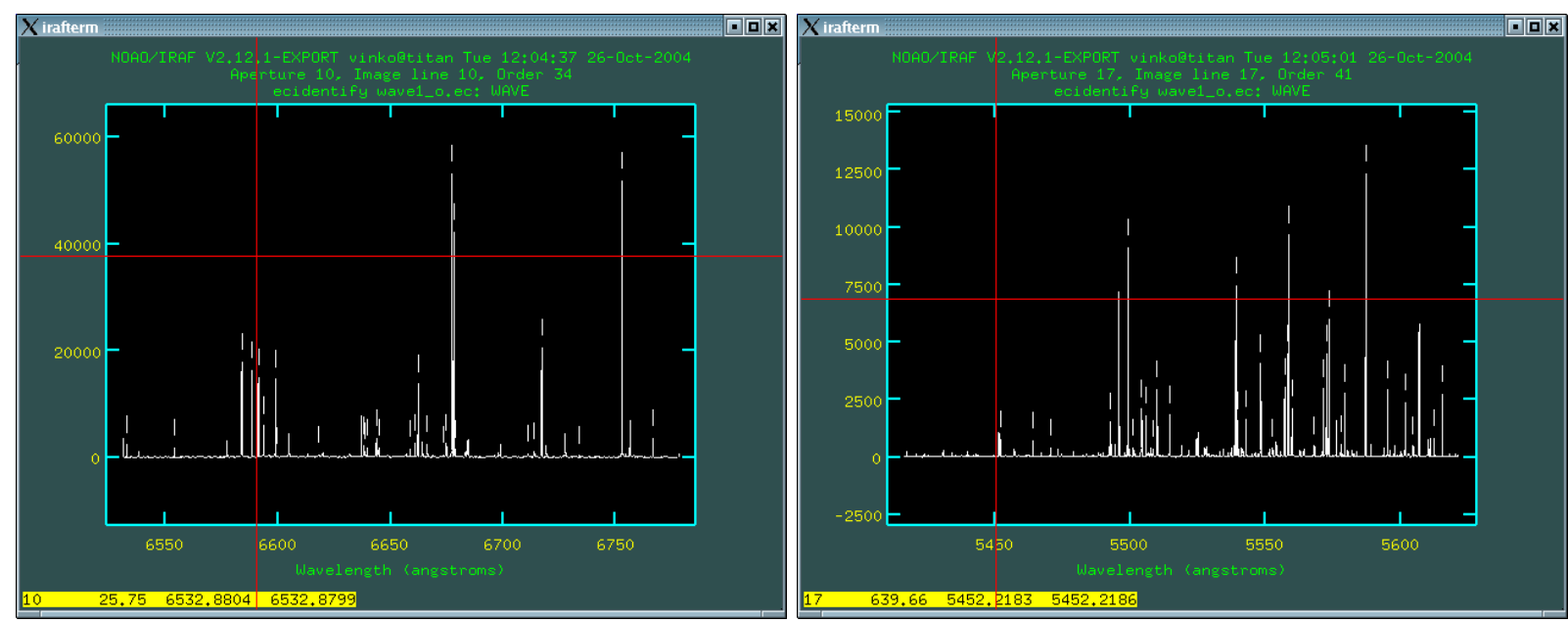

5.7. ábra. A kalibráló spektrállámpa spektrum emissziós vonalainak azonosítása.

lak mért pixelhelyzeteire (5.7.ábra). Végül a kapott objektum spektrumokat kontinuum-normáltuk úgy, hogy egy sima polinomot a lokális kontinuumszintekhez illesztettünk, amelyet interaktív módon határoztunk meg úgy, hogy kizártuk azokat a pixeleket, amelyek több mint a $2 \sigma$-val a helyi átlagtól eltérôek voltak.

A kiértékelést egy másik módszerrel is elvégeztük, mint azt már korábban említettem. Ennek során egy saját fejlesztésú CL-szkriptet használtunk, amely az általános echelle spektrumok redukálására és kalibrálására fejlesztett IRAF-rutinokat foglalja magába. A redukciós lépések alapvetően azonosak voltak a fentebb leírtakkal. A rendek megtalálása, lekövetése és kiintegrálása a képekből a noao.imred.echelle.apall taszkkal történt. Ebben az esetben háttér helyi fluxusértékéit helyenként határoztuk meg, minden rendre egyesével, majd külön-külön vontuk le ôket a rendek kiintegrálása közben. Az 5.8. ábrán a rendek követését és kiintegrálását láthatjuk az objektum képekre. 

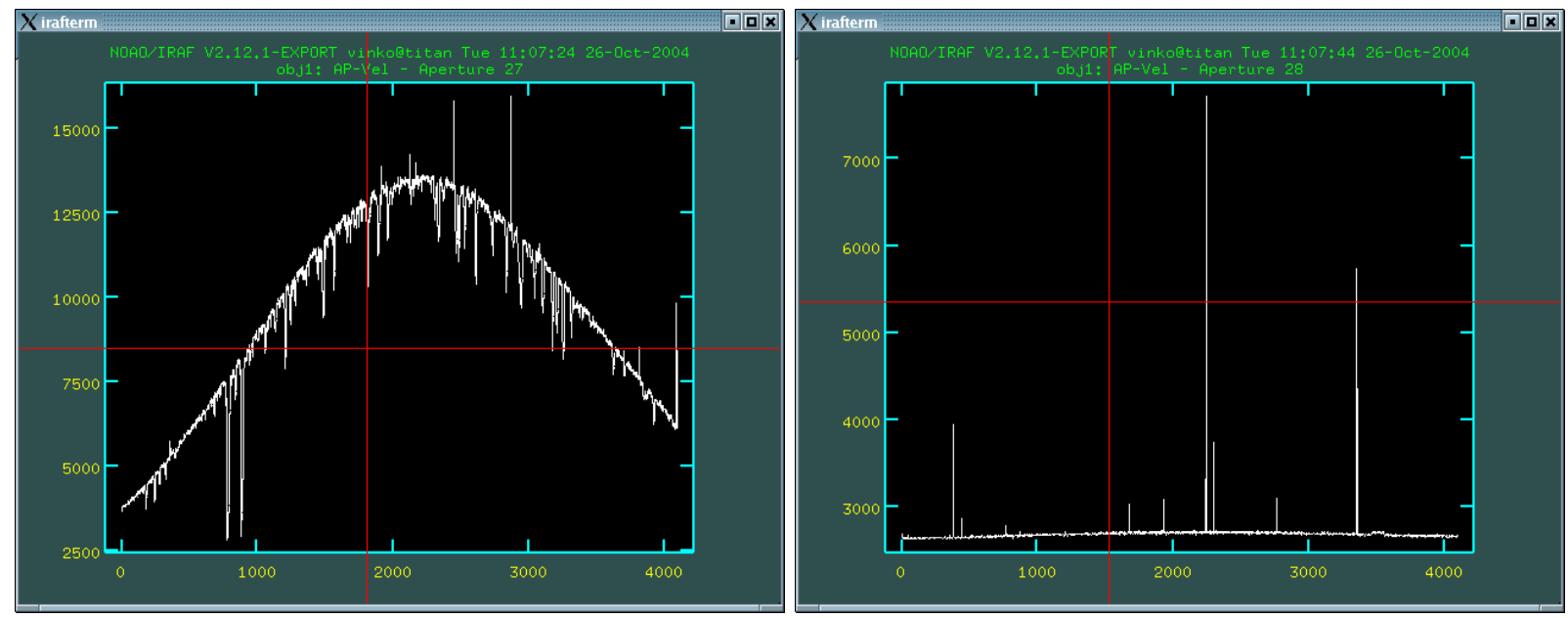

5.8. ábra. Rendek követése és kiintegrálása a objektum képeken.

A flatfield korrekciót a kinyert egyes rendekre szintén külön végeztük el. Ennél a módszernél a blaze-függvény azonnal eltávolításra került már ennél a lépésnél. Ellenben a flatfield lámpa képe még eltorzította a csillag és a háttér fluxusát ennél a szakasznál. Mivel a végsô célunk a kontinuum-normált spektrumok elérése volt, ez nem okozott problémát ennél a részfeladatnál, a végső kontinuum-normálásnál könnyen eltávolítottuk a flatfield spektrum kis mértékú torzítását. Valójában azt tapasztaltuk, hogy ez a módszer eredményesebb, mert szebb kontinuumot eredményezet a csillagok spektrumában, mint az elsô módszer. Ezt valószínúleg az okozza, hogy ennél a módszernél egyidejúleg illesztettük az erôsen változó blaze-függvényt és a csillag kontinuumát. Az első módszerhez hasonlóan a hullámhossz-kalibrálás itt is egy kétdimenziós polinomillesztést igényel a kinyert rendek és a kalibráló spektrállámpa megfelelő spektrum rendje között, ezt az imred.echelle.ecidentify taszkkal végeztük el. A hullámhossz-kalibráció során használt kétdimenziós polinom a következő volt:

$$
\lambda(x, m)=\frac{1}{m} \sum_{\mathrm{i}=1}^{n} \sum_{\mathrm{j}=1}^{p} a_{\mathrm{i}}, j x^{i} m^{j} .
$$

Az 5.9. ábrákon $n=3, p=3$, illetve $n=5, p=5$ beállítások melletti illesztések eredménye látszik.

A háttér (sky) apertúrák kalibrálásához az imred.echelle.ecreidentify taszkot használtuk, a megfelelő objektum hullámhossz-kalibrált apertúrájával kombinálva. Hasonlóan a dofoe taszk alkalmazásánál leírtakhoz, itt is megjelent a két apertúra, az objektum és a háttér apertúrák hullámhosszkalibrációja közötti enyhe nullponti eltolódás. Az égbolt spektrumának eltávolítása a csillagok spektrumából már a hullámhosszskála alapján történt, nem a pixelskálán, az imred.echelle.sarith taszkkal (5.10. ábra). Az egyes rendek hosszát manuálisan állítottuk be, a széleken lévő zajos részek levágásával (5.11. ábra). Végül az összes objektum spektrumot kontinuum-normáltuk a 

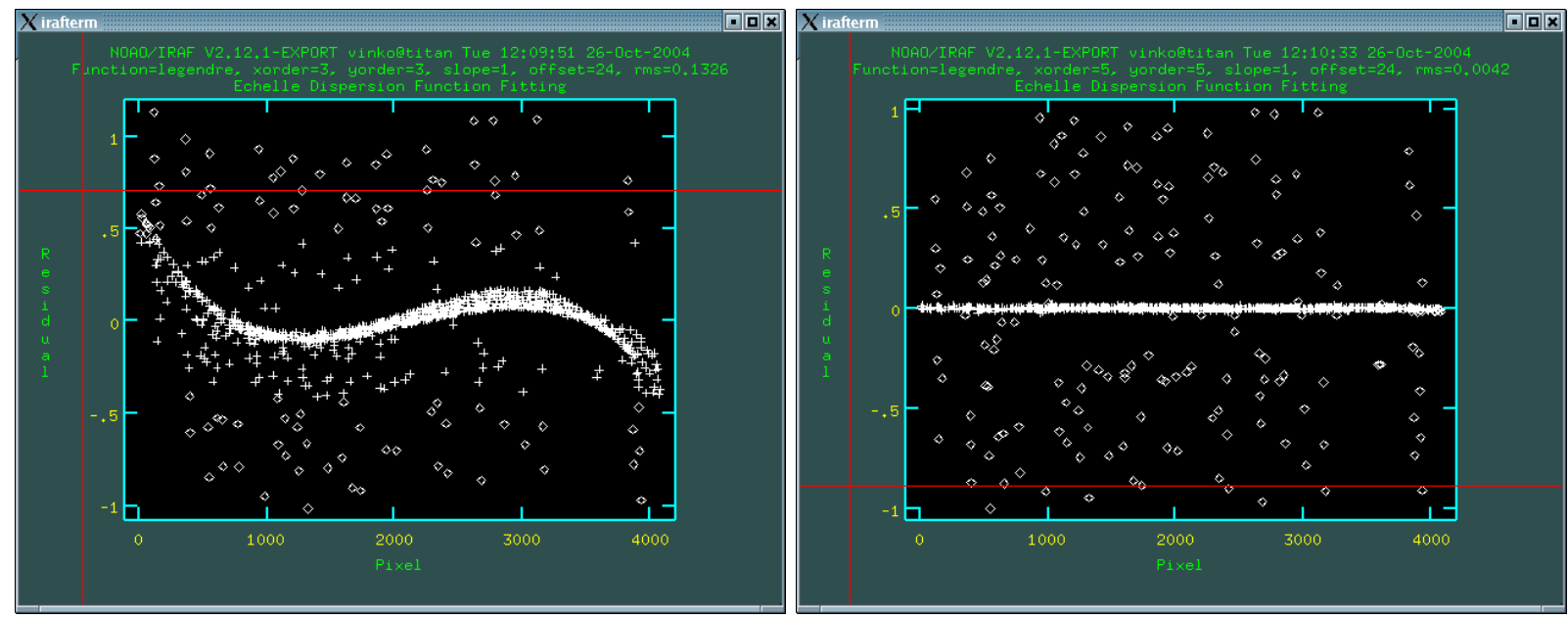

5.9. ábra. Hullámhossz-kalibráció - interaktív polinom illesztés eredményei.
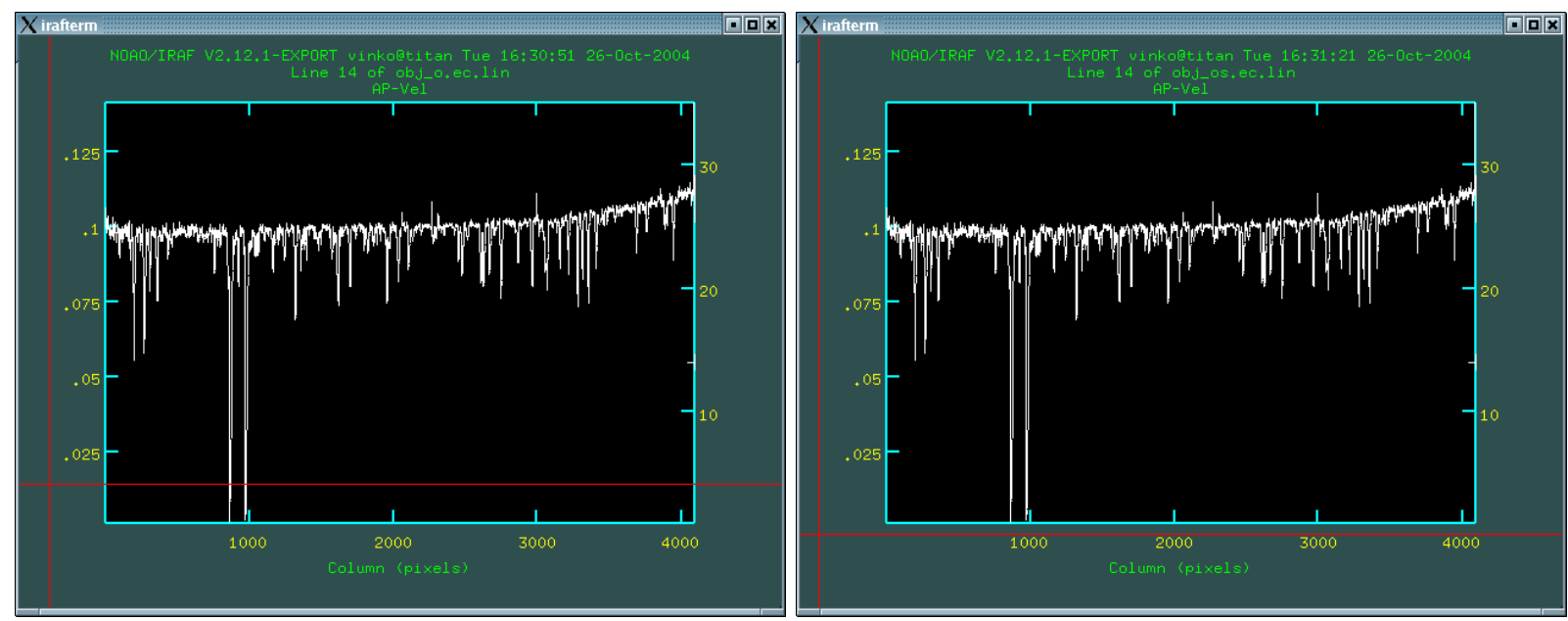

5.10. ábra. Égbolt levonása.

noao.imred.echelle.continuum taszk alkalmazásával(5.12. ábra).

A két független redukálási módszerrel kiredukált és hullámhossz-kalibrált végső spektrumokat rendrôl rendre összehasonlítottuk, és nagyon jó egyezést találtunk. Néhány spektrumot duplán is ellenőriztuik, az általunk kapott spektrumokat összevetettük a FEROS spektrumok redukálására kifejlesztett MIDAS programcsomaggal kiredukált spektrumokkal (Rainer, 2003). Nagyon jó egyezést találtunk, eltekintve attól, hogy egy kis hullámhossz-eltolódást találtunk, ami annak a ténynek köszönhető, hogy a MIDAS pipeline a végső spektrumok baricentrikus Doppler-korrekcióját is tartalmazza. A hullámhossz-kalibráció pontosságát a $\mathrm{H} \alpha$ vonal közelében lévő telluric vonalak hullámhosszaival hasonlítottuk össze, hiszen azok úgymond sebesség függetlenül a többi eszközzel felvett más spektrumokban is ugyanott kell, hogy elhelyezkedjenek. Tökéletes egyezést kaptunk, 1 pixelen belül egyezett a helyzetük $(\sim 0.05)$. Úgy gondoljuk, hogy erőfeszítéseink megbízható, megfelelően hullámhossz-kalibrált, kontinuum-normált FEROS spektrumokat eredményeztek 

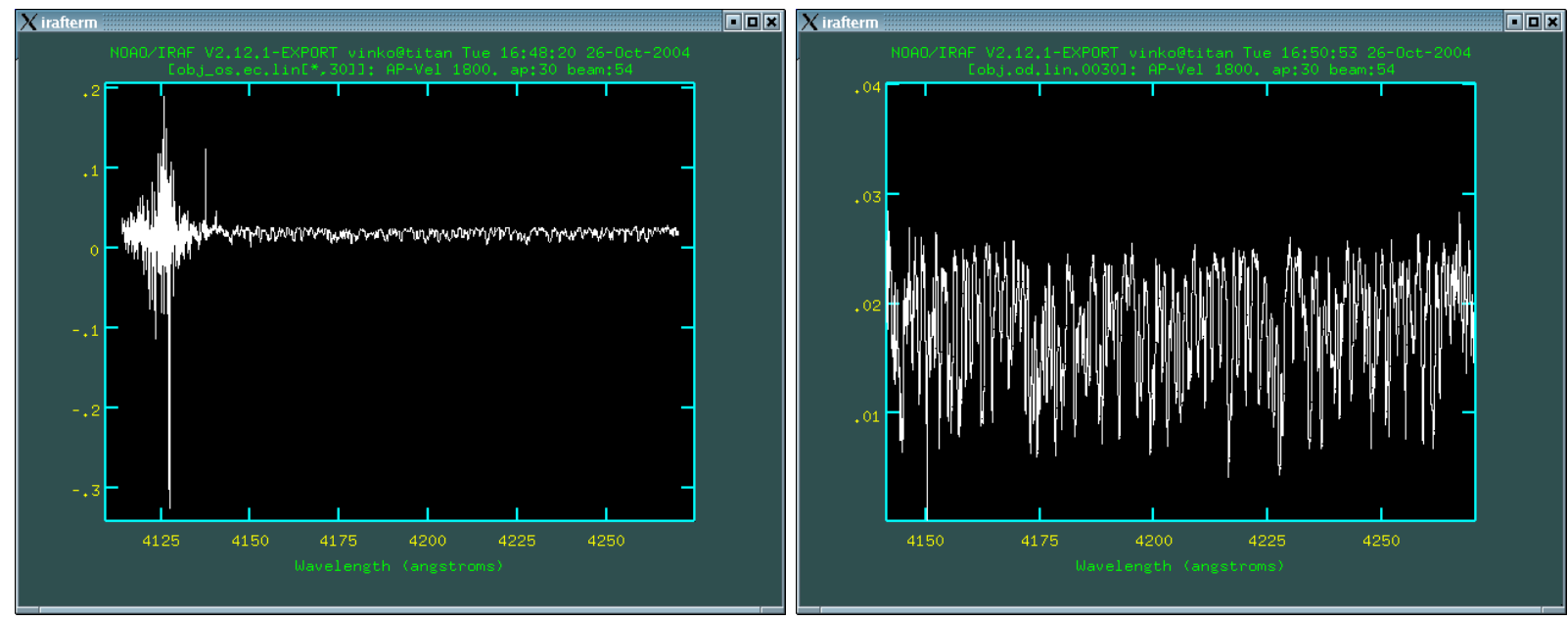

5.11. ábra. Rendek széleinek korrekciója.
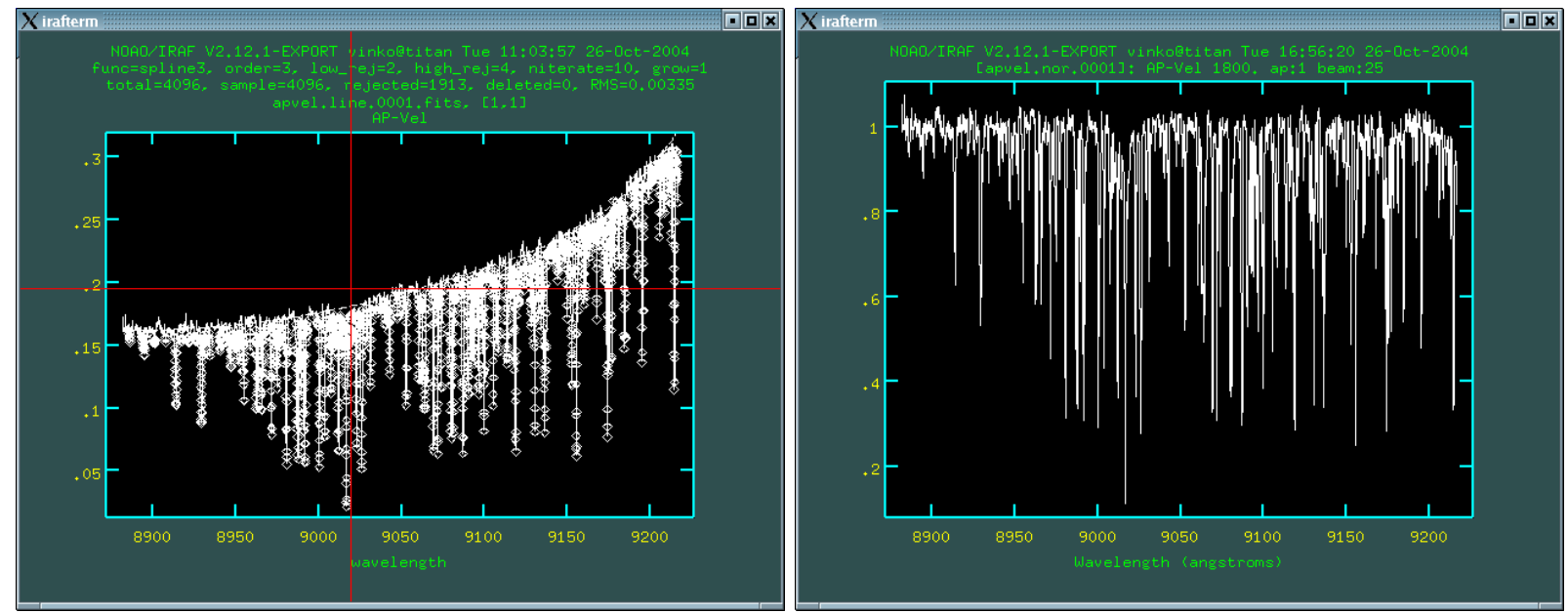

5.12. ábra. Kontinuum normálás. 
minden programcsillagunkra. Az IRAF programcsomagra írt redukáló és kalibráló CL-szkriptünk biztonságosan ajánlható minden felhasználó számára a MIDAS pipeline alternatívájaként (CLszkript a Függelékben).

\subsection{Kémiai analízis kivitelezése}

A programcsillagok fémtartalmának meghatározásához először a gyenge, ismert Fe I és Fe II vonalak listáját állítottuk össze, Kovtyukh \& Andrievsky (1999) cikke alapján, melyben egy kiterjedt vonallista található. A lista tartalmazza az egyes vonalak hullámhosszát, oszcillátorerősségét és gerjesztési potenciálját. Minden egyes vonalprofilt vizuálisan megvizsgáltunk, és a lehetséges blendeket kivettuik a listából. Az átvizsgálás után 77 Fe I és 18 Fe II vonalat kaptunk. Az 5.13. ábra az egyes vonalak azonosítását szemlélteti a Nap spektrumának segítségével.

A vonalak kiválasztása után az említett vonalak ekvivalens szélességét (EW) mértük meg az IRAF splot taszkjának segítségével. Először az egyes spektrumokat Doppler-korrigálni kellett (a dopcor taszkkal), hogy a vonalak a lehetô legközelebb legyenek a laboratóriumi hullámhosszukhoz. A korrekcióhoz a radiális sebességet a csillag spektrumának egy Nap-spektrummal való keresztkorrelációjából határoztuk meg. Erre azért van lehetőség, mert a Nap-spektrum megközelítőleg nulla radiális sebességgel rendelkezik a megfigyelő szemszögéből. A 20. echelle rendben, 5184 Å-nél található Mg I "b" triplet vonalat használtuk fel erre a célra, ami a késôi típusú csillagok radiálissebesség-vizsgálatainál gyakran használt átmenet. A keresztkorrelációs függvényt (CCF) az fxcor taszkkal számítottuk ki. Ezek után a korrigált spektrum kiválasztott vonalainak az ekvivalens szélességét Voigt-profil illesztésével kaptuk meg (splot taszk), ez az enyhe hullámhosszeltolódások korrigálását még lehetővé tette számunkra. Azokat a vonalakat, amelyeknél a laboratóriumi pozíciótól nagyobb, mint \pm 0,2 Åeltolódásokat kaptunk, a későbbi elemzésből kihagytuk.

Minden egyes vonal esetében a fémtartalom meghatározásához az R.O. Gray féle SPECTRUM $^{1}$ spektrális szintézis kódot használtuk. A SPECTRUM a sugárzási transzferegyenletet oldja meg, plán-parallel atmoszféramodellel, LTE-t feltételezve. Kurucz-féle modell atmoszférát használtunk, ahol $T_{\mathrm{eff}}=5000-7000 \mathrm{~K}, \log g=0-2,5 \mathrm{dex}$, ami általánosan jellemző a cefeidákra és a Naphoz hasonló csillagokra. A megfelelő atmoszféramodell kiválasztása után, adott lesz az effektív hőmérséklet $T_{\text {eff }}$, a $\log g$ és mikroturbulencia $v_{\mathrm{t}}$. LTE esetén a vizsgált kémiai elem, jelen esetben a vas gyakoriságát a következő összefüggés adja meg:

$$
A(F e)=\log \left(N_{\mathrm{Fe}} / N_{\mathrm{H}}\right)+12
$$

ahol $N_{\mathrm{Fe}}$ és $N_{\mathrm{H}}$ a vas és hidrogén koncentrációja, amit a BLACKWEL segédkóddal számoltunk ki minden egyes bemeneti vonalra. Az NLTE-effektus hatását az érintett vonalak számának mi-

\footnotetext{
${ }^{1}$ http://www.phys.appstate.edu/spectrum/spectrum.html
} 


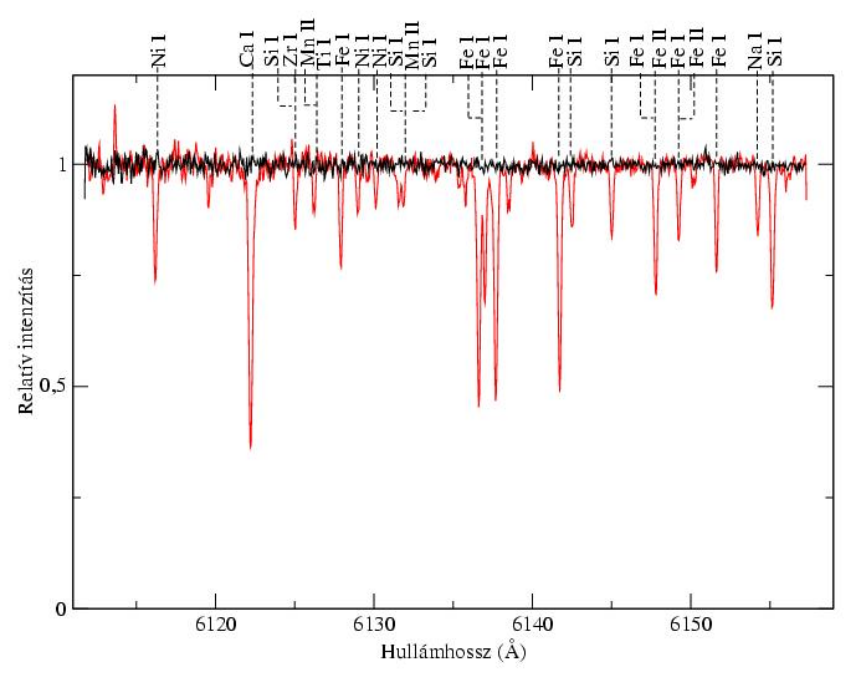

5.13. ábra. A kémiai elemek egyes vonalainak azonsítása szemléltetése a Nap-spektrum egy kis részletének segítségével

nimálisra csökkentésével próbáltuk kizárni, csak gyenge vonalakat használtunk fel, amelyekre $E W<0,15 \AA$.

A légköri paramétereket teljes mértékben a megfigyelt ekvivalens szélességekből határoztam meg, Fry \& Carney (1997) módszerét használva. Ebben a módszerben a tényleges hômérsékletet úgy választjuk meg, hogy a számított gyakoriságoknak (abundanciáknak) nem szabad függeniük a vonal gerjesztési potenciáljától. Hasonlóképpen, a felületi gravitációt akkor választjuk meg helyesen, ha a számított abundanciák mind az Fe I, mind a Fe II vonalakra azonosak (vagyis az abundanciák nem függnek az ionizációs állapottól). Mind a $T_{\mathrm{eff}}$, mind a $\log g$ értéket tovább pontosította, hogy a csillag H $\alpha$ profilját összevetettük a meghatározott $T_{\text {eff }}$, és $\log g$ értékekkel számított modellspektrumokkal. A modellspektrumokat az R. Kurucz publikus ATLAS9/SYNTHE kódjával készítettük . Végül a jól megválasztott mikroturbulens sebesség esetén a vonalabundanciák függetlenek a vonalak ekvivalens szélességeitől.

Az 5.14. ábrán a BQ Ser csillag jól megválasztott paraméterei esetén kapott összefüggéseket láthatjuk. A végsô fémtartalmat az a neutrális és ionizált vasatomok egyes vonalai esetén kapott fémtartalmak átlaga határozza meg. Az 5.15. ábra mindhárom panelén rosszul meghatározott paraméterekkel való ábrázolást látunk. A felsô panelen az effektív hőmérséklet értéke van rosszul beállítva, a középsó panelen a gravitáció, az alsón a $v_{t}$.

Ha lecsökkentjük a $T_{e f f}$ értékét az optimális 6000 K-ről 5500 K-re (felsố panel), a neutrális és ionizált vasvonalakból számolt abundanciák szeparálódnak, illetve a fémtartalom erốteljesen függeni fog a gerjesztési potenciáltól. Ha a korábban meghatározott mikroturbulenciát a 3,7 kms ${ }^{-1}$-ről $1,5 \mathrm{kms}^{-1}$-es mikroturbulenciára csökkentjük (alsó panel), szintén szépen elkülönülnek az ionizált, illetve neutrális vonalakból számolt fémtartalmak. A log g megváltoztatása 2,0 és 3,0 közötti érték 

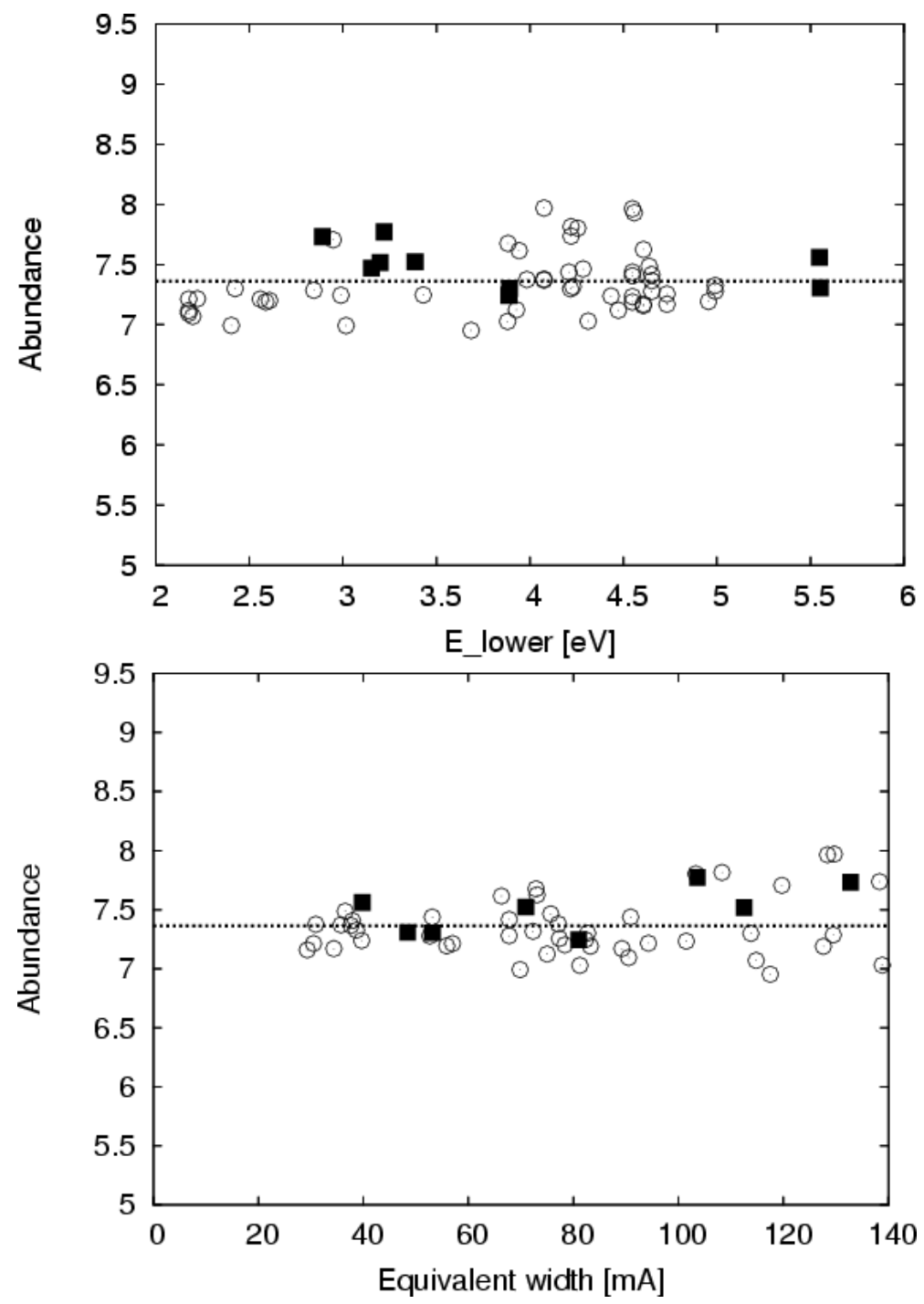

5.14. ábra. A BQ Ser csillag Fe tartalma az optimális légköri paraméterekkel. A $T_{\text {eff }}=$ $6000 K, \log g=2,0, v_{\mathrm{t}}=3,7 \mathrm{kms}^{-1}$; Az üres körök az Fe I vonalakat jelölik, a tele négyzetek az Fe II vonalakat (Sziládi et al., 2007). 

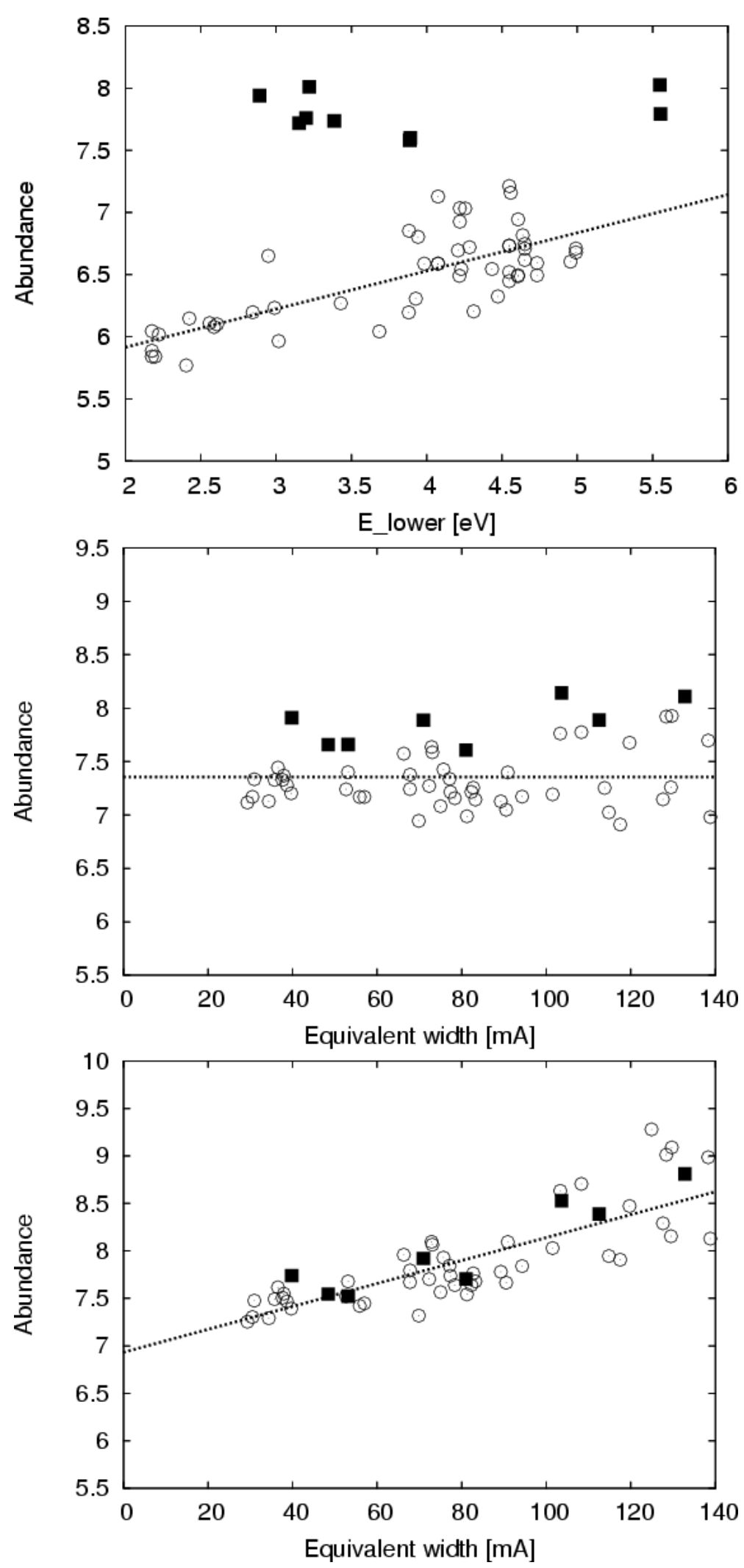

5.15. ábra. A BQ Ser csillag vonal abundanciájának a légköri paraméterektôl való függése. A szímbolumok az előző ábrával azonosak. A legfelsô panel: $T_{\text {eff }}=5500 \mathrm{~K}$, középsô panel: $\log g=$ 3,0, legalsó panel: $v_{\mathrm{t}}=1,5 \mathrm{kms}^{-1}$; A üres körök az Fe I vonalakat jelölik, a tele négyzetek az $\mathrm{Fe}$ II vonalakat (Sziládi et al., 2007). 


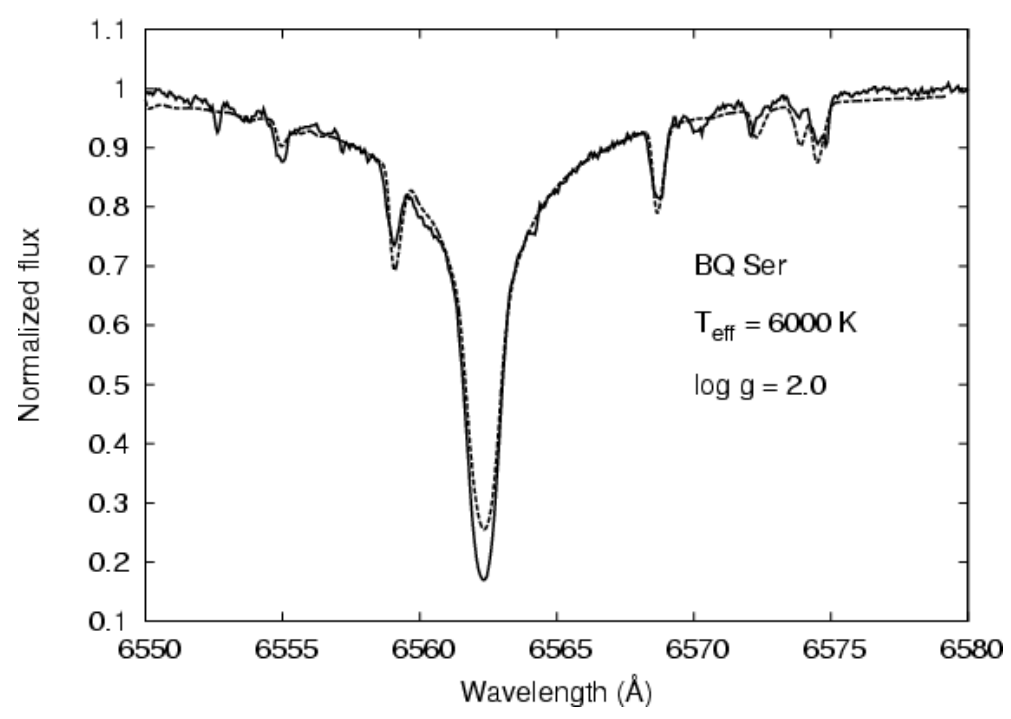

5.16. ábra. A BQ Ser csillag $H \alpha$ vonalának illesztése az ATLAS9 kóddal számolt spektrummal. A folytonos vonal a megfigyelt spektrumból származik, a pontozott vonal a modellspektrumból. A modellnél az $T_{\text {eff }}=6000 \mathrm{~K}$ és $\log g=2,0$ volt. Az illesztés során a vonal szárnyai szépen besimulnak, a vonalmagjánál tapasztaható vonalmélység különbség az LTE közelítésből származik (Sziládi et al., 2007).

között (középsô panel) szisztematikus különbséget eredményez a Fe I és Fe II vonalakból számított abundanciák között.

A $\mathrm{H} \alpha$ vonal profilját mutatja az 5.16. ábra. A H $\alpha$ vonal nagyon érzékeny a fotoszférikus hômérsékletre és a nyomásra. A H $\alpha$ vonal esetén a vonal magjának kialakulásában az NLTE hatásai vannak nagyobb mértékben, mégis a vonal szárnyai nagyon jó fotoszférikus hőmérséklet és gravitáció jelzők. Így az ellenőrzésnél a megfigyelt spektrum és a modell spektrum egyezése csak a H $\alpha$ vonal szárnyaira korlátozódik. Mivel a fémtartalom csak gyengén függ a log $g$ értékének megválasztásától (lásd az 5.16. ábrát), a H $\alpha$ vonalprofil illesztése fontos korlátokat jelentett ehhez a paraméterhez.

A BLACKWEL abundancia skálájának egyik tesztelésére, pontosságának ellenőrzésére a nappali égboltról készült Nap-spektrumok elemzését végeztük el a korábban leírt vonallista alapján. A Kurucz-féle napatmoszféra-modellt használtuk a következő paraméterekkel, $T_{\text {eff }}=5777$ $\mathrm{K}, \log g=4,4377, v_{\mathrm{t}}=1,5 \mathrm{~km} \mathrm{~s}^{-1}$ ). Az eredményeket

5.2. táblázat. A Nap spektrumából kimért vas-abundanciák.

\begin{tabular}{lcc}
\hline Dátum & $A_{\odot}(\mathrm{Fe})$ & $\sigma$ \\
\hline május 30. & 7,44 & 0,18 \\
május 31. & 7,52 & 0,18 \\
június 1. & 7,51 & 0,17 \\
\hline
\end{tabular}

Az eredményekben tapasztalható bizonytalanságokat a vonalabundanciák átlagos szórása alapján becsültük meg. Látható, hogy az első napon (május 30-án) készült spektrum esetében a kiszá- 
mított abundancia kisebb, mint a két másik napon készülteknél, ám az értékek így is $1 \sigma$-án belül vannak. Így a végső értéknek a három érték súlyozatlan átlagát fogadtuk el: $A_{\odot}(F e)=7,49 \pm$ 0,18 . Ez az érték nagyon jó egyezést mutatott a cikkünk megjelenésekor elfogadott 7,45 $\pm 0,05$ vastartalom értékkel (pl. Asplund et al., 2005). A munkánk során a továbbiakban az $A_{\odot}(\mathrm{Fe})=$ 7,49 értéket használtunk fel.

\subsection{Fémesség meghatározása fotometriai adatokból}

A dolgozatban már sokszor szóba került, hogy a csillagpulzáció szempontjából az egyik legfontosabb paraméter a fémesség; például a klasszikus cefeidák esetén a periódus-fényesség relációban tapasztalható szórás is a fémtartalomtól való függésre utal (lásd pl. Szabados \& Klagyivik, 2012; Wielgórski et al., 2017). Mostanáig közel 200 tejútrendszerbeli cefeida fémességét határozták meg nagy felbontású spektroszkópia alapján (pl. Luck \& Lambert, 2011). Újabban ezt a technikát sikerült a Nagy- és Kis-Magellán-felhőben található néhány cefeidára is kiterjeszteni (Lemasle et al., 2017). A nagy felbontású spektroszkópia azonban még mindig nem alkalmazható például a Magellán-felhőkben található pulzáló csillagok mindegyikére, nem beszélve a távolabbi extragalaxisok cefeidáiról. A probléma még összetettebbé válik, ha a modern égboltfelmérô programok által szolgáltatott igen nagy mennyiségú adathalmazt vesszük alapul: a legújabb fotometriai katalógusok mintegy $10^{9}$ forrást tartalmaznak, míg a spektroszkópiai felmérések adatainak száma csupán néhány millió fényforrásra korlátozódik (pl. Miller et al., 2015).

Korábban többen próbálkoztak azzal, hogy a pulzáló csillagok fémtartalmát fotometriai úton becsüljék meg. Nagyon jó példa erre a Kovács \& Zsoldos (1995), illetve a Jurcsik \& Kovács (1996) cikkekben bemutatott módszer, amely az RR Lyrae csillagok $[\mathrm{Fe} / \mathrm{H}]$ értékeinek meghatározását teszi lehetôvé a csillagok fénygörbéjének Fourier-paramétereiből. Módszerük a Fourier-paraméterek és a fémesség közötti empirikus korrelációra alapul. Rámutattak arra, hogy az RR Lyrae fénygörbék esetében a fémesség szempontjából a legérzékenyebb paraméter a 3. és az 1. harmonikus közötti fáziskülönbség, $\varphi_{31}=\varphi_{3}-3 \varphi_{1}$. Tulajdonképpen már az 1990-es években Zsoldos (1995) is hasonló eredményt kapott egy kisszámú cefeida csoport fénygörbéje alapján, de ez a tanulmány akkor nem alapulhatott pontos spektroszkópiai [Fe/H] értékeken.

Ezt a korai próbálkozást fejlesztették tovább a közelmúltban, Klagyivik et al. (2013). Nagyszámú galaktikus klasszikus cefeidára elvégzett modern, nagy felbontású spektroszkópiai fémességekből azt találták, hogy az alapmódusban pulzáló rövid periódusú klasszikus cefeidák esetén a fénygörbe amplitúdói érzékeny mutatói a fémességnek. Felállítottak egy empirikus korrelációt a $[\mathrm{Fe} / \mathrm{H}]$ és a a Fourier-harmonikusok amplitúdóinak aránya $\left(R_{21}=A_{2} / A_{1}\right.$ és $R_{31}=A_{3} / A_{1}$, Simon \& Lee, 1981) között. Ezek alapján minél kisebb a fémesség annál nagyobbak ezek az amplitúdó arányok. Klagyivik és munkatársai (Klagyivik et al., 2013) szerint a Nagy-Magellán-felhőben, illetve a Kis-Magellán-felhőben található cefeidák, amelyeknek alacsonyabb fémtartalmuk van, várhatóan nagyobb amplitúdóarányokat mutatnak majd, mint tejútrendszerbeli társaik. Nem tud- 
ták azonban ezeket a feltételezéseket alátámasztani, mert akkoriban a Magellán-felhốk cefeidáiról nem volt elérhető megbízható spektroszkópiai fémességadatok.

A kétmódusú cefeidák esete azért különleges ebben a helyzetben, mert a már korábban ismertetett periódusarány - fémesség reláció lehetőséget ad arra, hogy pontos becslést adjunk a Tejútrendszeren kívül elhelyezkedő kétmódusú cefeidák fémességére is (Buchler \& Szabó, 2007; Sziládi et al., 2007; Buchler, 2008; Chekhonadskikh, Kovtyukh \& Belik, 2014). A spektroszkópiai mérésekre alapuló reláció lehetôséget biztosít arra, hogy megvizsgáljuk, vajon a fénygörbe alakját milyen módon befolyásolja a fémesség. Chekhonadskikh, Kovtyukh \& Belik (2014) ezt az ötletet alkalmazta a Magellán-felhőkben található cefeidákra. A mikrolencse felmérések, például az EROS (Marquette et al., 2009) és az OGLE-III (Soszynski et al., 2008, 2010) programok során kapott fénygörbéket felhasználva meghatározták a Magellán-felhők kis felbontású fémesség térképét a beat cefeidák térbeli eloszlása alapján.

Munkánk során mi is ugyanezt a technikát alkalmaztuk. Megvizsgáltuk, hogy Klagyivik és munkatársaik által meghatározott amplitudóarány-fémesség korreláció valóban alkalmazható-e az alacsonyabb fémességek esetében is. Ehhez a Tejútrendszerben ismert alapmódusban és elsố felhangban pulzáló cefeidák homogenizált $[\mathrm{Fe} / \mathrm{H}]$ értékeit használtuk fel, melyek nagy felbontású spektroszkópiából származnak. A spektroszkópiai úton kapott pontosabb fémtartalmak lehetôséget adtak arra, hogy egy precíz, finomított periódusarány-fémesség összefüggés ismeretében a Magellán-felhők cefeidáinak fémtartalmára is pontos számításokat végezzünk. Az OGLE-III és OGLE-IV adatbázisokban alap- és elsô felhangban pulzáló beat cefeidák nagyszámú fénygörbéje található. Ezen csillagokra a pulzációs periódusok ismeretében a relációnk alapján tudtunk fémességet meghatározni, majd ezeket a fémességértékeket hasonlítottuk össze a fénygörbékből nyert Fourier-paraméterek lineáris kombinációival. Végül a kapott eredményeinket összehasonlítottuk a Klagyivik és munkatársai által megadott előrejelzésekkel. 


\section{6. fejezet}

\section{Tudományos eredmények}

Az alábbiakban részletesen bemutatom az előző fejezetben szereplő mérések feldolgozásából származó új tudományos eredményeimet.

\subsection{Kétmódusú cefeidák új, spektroszkópiai $[\mathrm{Fe} / \mathrm{H}]$ értékei}

A 6.1. táblázatban láthatóak az általunk meghatározott fémtartalmak és a hozzájuk tartozó légköri paraméterek. A táblázatban csillagra és éjszakákra lebontva találjuk az adatokat, hiszen a csillaglégkörök paraméterei a pulzáció miatt éjszakáról-éjszakára változhatnak. Az effektív hômérsékletre $\left(T_{\text {eff }}\right)$ kapott értékek $\pm 250 \mathrm{~K}$ bizonytalanságúak, míg a $\log g \pm$-re ez 0,25 dex. Ezek a bizonytalansági értékek a modellatmoszférák lépésközei miatt vannak, mert az egyes modellek között $250 \mathrm{~K} T_{\text {eff }}$ különbség van, a $\log g$ paraméterek pedig 0,25-ös közökkel követik egymást. Hasonló ok miatt a mikroturbulencia $\pm 0,5 \mathrm{kms}^{-1}$ bizonytalansággal határozható meg. Az abundanciák hibáját az átlagértékek körüli átlagos szórással jellemeztuik.

Fontos kitérni arra is, hogy az általunk meghatározott gravitációs gyorsulások az éppen aktuális pulzációs fázistól függő effektív gravitációt tartalmazzák. Az effektív gravitáció a következő képlettel adható meg:

$$
g_{\mathrm{eff}}=\frac{G M}{R^{2}(t)}-p \frac{d v_{\mathrm{rad}}}{d t}
$$

ahol $M$ a csillag tömege, $R(t)$ a fotoszféra pillanatnyi sugara, $v_{\text {rad }}$ az észlelés pillanatában mért radiális sebesség, $p$ a radiális sebesség és a pulzációs sebesség közötti korrekciós faktor. A számításaink során $p=1,38$-at értéket használtunk, ami Gieren et al. (1999) által megadott képletből származik.

Ahhoz, hogy a csillagok tényleges gravitációjáról pontos információt kapjunk, először a radiálissebességgörbékből meg kellett határoznunk a gyorsulásokat. A radiális sebesség értékeket ehhez korábbi 
cikkekből gyújtöttük össze, Stobie \& Balona (1979), Gorynya et al. (1992, 1996, 1998), Bersier et al. (1994), Antipin et al. (1999), és Petterson et al. (2004) munkáit felhasználva. Minden cefeida esetén a radiálissebesség-görbékre egy Fourier-polinomot illesztettünk, amely $f_{0}, f_{1}, f_{0}+f_{1}$, $f_{1}-f_{0}$, és $2 f_{0}+f_{1}$ frekvencia tagokból állt. A számoláshoz szükséges periódusokat a 5.1. táblázat tartalmazza. Mivel ezek a periódusok hosszú időszak megfigyelései alapján lettek meghatározva, így ezeket nyugodtan felhasználtuk az új megfigyeléseink esetén is. A gyorsulás már kiszámítható volt a Fourier-polinomok ismeretében az adott észlelés pillanatában az előbb megadott egyenlet alapján. A 6.1. táblázat tartalmazza minden egyes csillaghoz a kiszámított gravitációs gyorsulásokat is.

Ugyanebben a táblázatban szerepelnek a kémiai abundancia értékek is, amelyek az adott csillag esetén észlelési időponttól, pulzációs fázistól függenek. Ezen adatok elemzése lehetôvé tette a módszer stabilitásának vizsgálatát, illetve az esetleges szisztematikus hibák felfedését. Az adatokat megnézve elmondhatjuk, hogy az egyes csillagokra kapott értékek hibahatáron belül megegyeznek. Azonban a harmadik napon (június 1.) készült spektrumokból származó abundanciák kissé alacsonyabbaknak adódtak (de $1 \sigma$-n belüliek), mint az elsố éjszaka (május 30.) készült spektrumokból számítottak. Az atmoszférikus paraméterek nem mutatnak ilyen tendenciát. Ezt az enyhe ellentmondást egy instrumentális kalibrációs problémának tulajdonítjuk: valószínúleg a szórt fény és az égi háttér eltávolításával van összefüggésben, amely megváltoztathatja a kontinuum-normált spektrumok vonalmélységét. Mindazonáltal, mivel a különbségek nem szignifikánsak, a végsô fémtartalmakat a 6.1. táblázatban megadott értékek átlagaként határoztuk meg (lásd 6.2. táblázat). Ezek becsült bizonytalanságai figyelembe veszik az egyedi mérések hibáit, valamint a különböző éjszakákhoz tartozó adatok közötti különbségeket.

A 6.2. táblázat a csillagokra kapott új $[\mathrm{Fe} / \mathrm{H}]$ értékeket is tartalmazza, melyeket a következő egyenletből számítottunk ki:

$$
[\mathrm{Fe} / \mathrm{H}]=A_{\mathrm{Ceph}}(\mathrm{Fe})-A_{\odot}(\mathrm{Fe})
$$

ahol $A_{\odot}(\mathrm{Fe})=7,49$ értékkel számoltunk, ennek magyarázatáról fentebb már szó esett. A kapott eredményeket átnézve, azt tapasztaljuk, hogy a 17 kétmódusú cefeida közül 14 kissé negatív [Fe/H] értéket mutat, de figyelembe véve a hibahatárokat, elmondhatjuk, hogy a Nap fémességértékétől való eltérés marginális.

Az újonnan meghatározott fémességértékeket egy független úton még leellenôriztük. Az ATLAS9 program és a Kurucz-féle modellek segítségével szintetizált spektrumokat hoztunk létre. Fontos megjegyezni, hogy a Kurucz-modellekben alkalmazott fémesség a Napra eltér az általunk a számításokban használt értéktől. A modellek a vas 7,63-as abundanciájával számolnak, míg mi 7,49-nek vettük ezt az értéket. Így az összehasonlításhoz az "abundancia skálát" a következô módon kellett korrigálni: $10^{[A(\mathrm{Fe})-7,63]}$, ahol $A(\mathrm{Fe})$ az adott cefeida fémesség abundanciája. A szin- 


\begin{tabular}{|c|c|c|c|c|c|c|c|c|c|}
\hline Csillag & Dátum & $\overline{\mathrm{S} / \mathrm{N}}$ & $\begin{array}{l}T_{\text {eff }} \\
(\mathrm{K})\end{array}$ & $\begin{array}{l}\log g \\
(\operatorname{dex})\end{array}$ & $\begin{array}{c}\log g+a \\
(\mathrm{dex})\end{array}$ & $\begin{array}{c}v_{\mathrm{t}} \\
\left(\mathrm{km} \mathrm{s}^{-1}\right)\end{array}$ & $\begin{array}{l}A(\mathrm{Fe}) \\
(\mathrm{dex})\end{array}$ & $\begin{array}{c}\sigma \\
(\mathrm{dex})\end{array}$ & $\begin{array}{c}\left\langle v_{\mathrm{e}} \sin i\right\rangle \\
\left(\mathrm{km} \mathrm{s}^{-1}\right)\end{array}$ \\
\hline \multirow[t]{2}{*}{ Y Car } & máj. 30 & 187 & 6000 & 2,0 & 1,92 & 4,1 & 7,45 & 0,19 & 0 \\
\hline & jún. 1 & 270 & 7000 & 2,5 & 2,48 & 4,1 & 7,43 & 0,14 & 10 \\
\hline \multirow[t]{2}{*}{ EY Car } & máj. 30 & 142 & 6000 & 1,0 & - & 4,2 & 7,39 & 0,24 & - \\
\hline & jún. 1 & 139 & 5750 & 1,5 & - & 4,2 & 7,24 & 0,20 & 20 \\
\hline \multirow{2}{*}{ GZ Car } & máj. 30 & 158 & 6250 & 2,0 & 2,06 & 5,0 & 7,49 & 0,22 & 0 \\
\hline & jún. 1 & 125 & 6000 & 2,0 & 1,98 & 5,0 & 7,35 & 0,19 & 0 \\
\hline \multirow[t]{2}{*}{ UZ Cen } & máj. 30 & 210 & 6000 & 1,0 & 2,06 & 3,8 & 7,31 & 0,21 & 4 \\
\hline & jún. 1 & 168 & 5750 & 1,5 & 1,59 & 4,2 & 7,29 & 0,14 & 8 \\
\hline \multirow[t]{2}{*}{ BK Cen } & máj. 30 & 201 & 6000 & 2,0 & 2,08 & 4,0 & 7,65 & 0,16 & 10 \\
\hline & jún. 1 & 151 & 6000 & 2,0 & 2,17 & 4,0 & 7,48 & 0,23 & 4 \\
\hline \multirow[t]{2}{*}{ V1048 Cen } & máj. 30 & 161 & 6250 & 2,0 & - & 4,2 & 7,37 & 0,23 & 7 \\
\hline & jún. 1 & 189 & 6250 & 2,0 & - & 4,2 & 7,25 & 0,22 & 5 \\
\hline VX Pup & jún. 1 & 274 & 6500 & 2,5 & 2,51 & 4,4 & 7,29 & 0,14 & 10 \\
\hline \multirow[t]{3}{*}{ EW Sct } & máj. 30 & 150 & 5750 & 1,5 & 1,57 & 3,8 & 7,48 & 0,16 & 10 \\
\hline & máj. 31 & 197 & 6000 & 1,5 & 0,00 & 3,8 & 7,54 & 0,18 & 10 \\
\hline & jún. 1 & 228 & 6250 & 2,0 & 2,04 & 3,6 & 7,43 & 0,20 & 10 \\
\hline \multirow[t]{2}{*}{ V367 Sct } & máj. 30 & 151 & 6000 & 1,5 & 1,33 & 4,5 & 7,54 & 0,21 & 15 \\
\hline & máj. 31 & 146 & 6250 & 2,0 & 2,02 & 4,5 & 7,59 & 0,22 & 15 \\
\hline \multirow[t]{2}{*}{ V458 Sct } & máj. 30 & 218 & 6250 & 2,0 & 1,98 & 4,2 & 7,55 & 0,19 & 16 \\
\hline & máj. 31 & 183 & 6250 & 2,5 & 2,54 & 4,2 & 7,61 & 0,17 & 11 \\
\hline \multirow[t]{3}{*}{ BQ Ser } & máj. 30 & 133 & 5750 & 2,0 & 1,81 & 3,7 & 7,34 & 0,21 & 17 \\
\hline & máj. 31 & 139 & 6000 & 2,0 & 1,97 & 3,9 & 7,39 & 0,27 & 16 \\
\hline & jún. 1 & 169 & 6000 & 2,0 & 2,03 & 3,7 & 7,36 & 0,25 & 14 \\
\hline \multirow[t]{2}{*}{$\mathrm{U} \operatorname{Tr} \mathrm{A}$} & máj. 30 & 300 & 6000 & 2,0 & 2,04 & 4,8 & 7,43 & 0,14 & 5 \\
\hline & jún. 1 & 270 & 6000 & 2,0 & 2,33 & 4,8 & 7,25 & 0,18 & 0 \\
\hline \multirow[t]{2}{*}{ AP Vel } & máj. 30 & 126 & 5750 & 1,5 & 0,00 & 3,9 & 7,51 & 0,17 & 18 \\
\hline & jún. 1 & 154 & 6000 & 2,0 & 2,01 & 3,9 & 7,35 & 0,20 & 10 \\
\hline \multirow[t]{2}{*}{ AX Vel } & máj. 30 & 328 & 6500 & 2,5 & 2,52 & 5,1 & 7,54 & 0,17 & 10 \\
\hline & jún. 1 & 232 & 6250 & 2,0 & 2,17 & 5,1 & 7,26 & 0,19 & 13 \\
\hline GSC 8607-0608 & máj. 30 & 169 & 5750 & 1,5 & 1,50 & 3,7 & 7,38 & 0,22 & 7 \\
\hline \multirow[t]{2}{*}{ GSC 8691-1294 } & máj. 31 & 66 & 6250 & 2,5 & - & 3,6 & 7,48 & 0,30 & 15 \\
\hline & jún. 1 & 274 & 6000 & $2,0_{56}$ & - & 3,3 & 7,46 & 0,15 & 15 \\
\hline
\end{tabular}




\begin{tabular}{lcccccc}
\hline \hline \multicolumn{1}{c}{ csillag } & $\begin{array}{c}{[\mathrm{Fe} / \mathrm{H}]} \\
(\mathrm{dex})\end{array}$ & $\begin{array}{c}\sigma \\
(\mathrm{dex})\end{array}$ & $\begin{array}{c}{[\mathrm{Fe} / \mathrm{H}]_{1}} \\
(\mathrm{dex})\end{array}$ & $\begin{array}{c}{[\mathrm{Fe} / \mathrm{H}]_{2}} \\
(\mathrm{dex})\end{array}$ & $\begin{array}{c}{[\mathrm{Fe} / \mathrm{H}]_{3}} \\
(\mathrm{dex})\end{array}$ & $\begin{array}{c}{[\mathrm{Fe} / \mathrm{H}]_{4}} \\
(\mathrm{dex})\end{array}$ \\
\hline Y Car & $-0,05$ & 0,16 & $-0,33(0,35)$ & - & - & - \\
EY Car & $-0,17$ & 0,22 & - & - & - & - \\
GZ Car & $-0,07$ & 0,20 & $-0,36(0,33)$ & $-0,08$ & - & - \\
UZ Cen & $-0,19$ & 0,17 & $-0,30(0,32)$ & $-0,09$ & - & - \\
BK Cen & 0,07 & 0,19 & $-0,03(0,30)$ & - & - & - \\
VX Pup & $-0,20$ & 0,14 & $-0,39(0,14)$ & $-0,17$ & $-0,13$ & $-0,15(0,12)$ \\
EW Sct & $-0,01$ & 0,18 & $-0,08(0,09)$ & - & $+0,03$ & - \\
V367 Sct & 0,075 & 0,21 & $+0,26(0,30)$ & - & $-0,01$ & - \\
V458 Sct & 0,09 & 0,18 & - & - & - & - \\
BQ Ser & $-0,13$ & 0,24 & $-0,36(0,20)$ & $-0,08$ & $-0,05$ & - \\
U TrA & $-0,15$ & 0,16 & $-0,31(0,34)$ & - & - & - \\
AP Vel & $-0,06$ & 0,18 & $-0,18(0,35)$ & $-0,045$ & - & - \\
AX Vel & $-0,09$ & 0,18 & $-0,43(0,29)$ & $-0,12$ & - & $-0,15(0,07)$ \\
GSC 8607-0608 & $-0,11$ & 0,22 & - & - & - & - \\
GSC 8691-1294 & $-0,015$ & 0,22 & - & - & - & - \\
TU Cas & $-0,16$ & 0,24 & $-0,43(0,31)$ & $-0,05$ & 0,02 & - \\
& & & & & & - \\
V1048 Cen & $-0,18$ & 0,22 & - & - & - & - \\
\hline
\end{tabular}

6.2. táblázat. Végső (átlagolt) fémességek és a hozzájuk tartozó szórások, illetve a korábbi cikkekben szereplő $[\mathrm{Fe} / \mathrm{H}]$ értékek. Az utóbbi adatok esetében a szórás értékek (amennyiben rendelkezésre állnak) zárójelben vannak megadva.

Referenciák: 1: Andrievsky et al. (1994); 2: D'Cruz et al. (2000); 3: Andrievsky et al. (2002); 4 : Lemasle et al. (2007). 

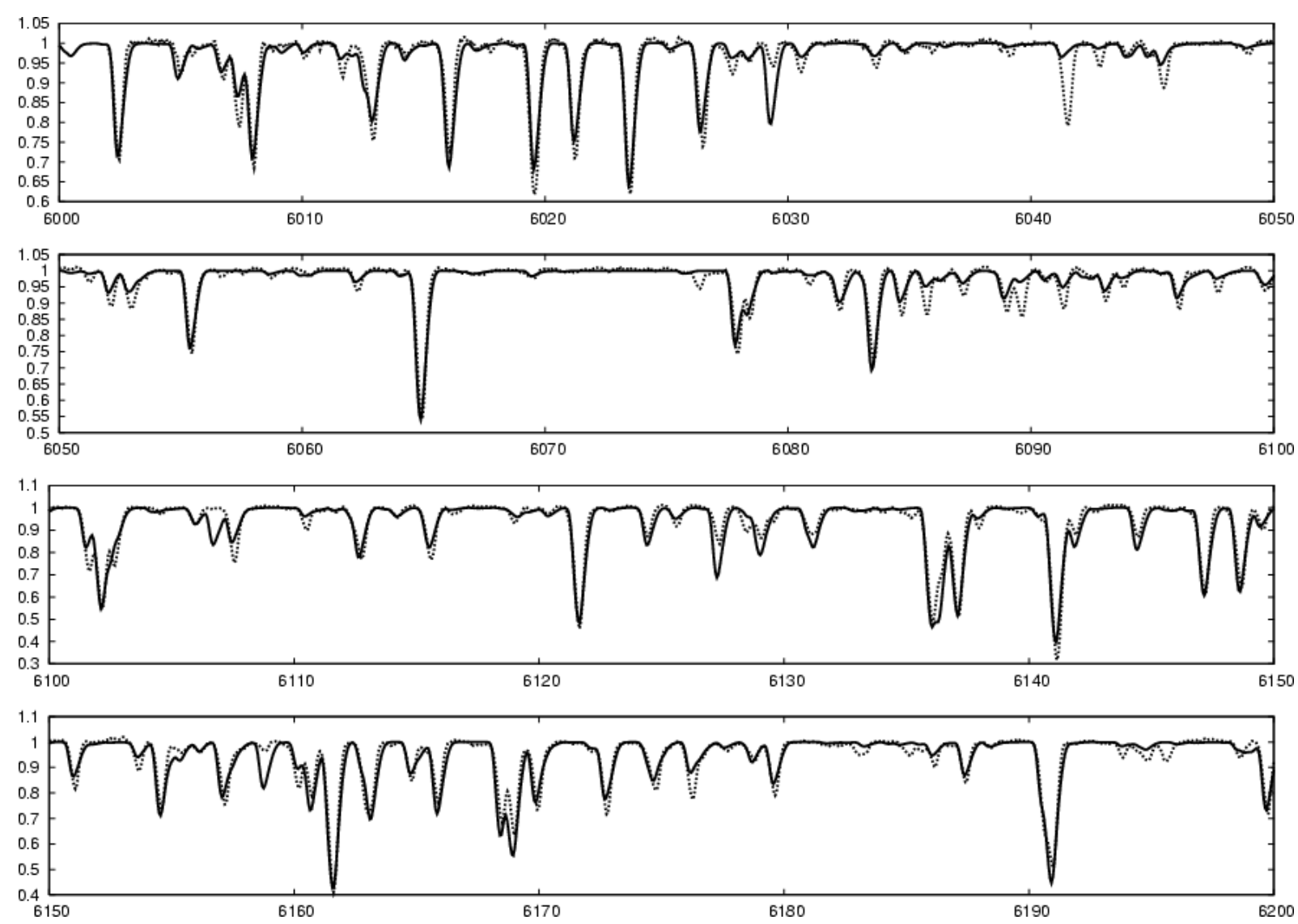

6.1. ábra. Az EW Scuti csillag (pontozott vonal) megfigyelésból származó spektrumának és az általunk készített modellspektrumnak az összehasonlítása (folytonos vonal).

tetikus spektrumok számolásánál figyelembe vettük a cefeidák pulzációjának hatását is. Erre az ATLAS9 programcsomag VFIELD nevú modulját használtuk, amely a sztatikus atmoszféra vonalprofiljait konvolálja a radiálissebesség-vektorok felszíni eloszlásával, létrehozva a pulzáció miatt kissé aszimmetrikus vonalprofilt. Radiális sebességként a korábban meghatározott sebességértéket adtuk meg minden egyes csillagra. Az ebből kapott elméleti spektrumokat végül konvoláltuk a FEROS spektrográf instrumentális vonalkiszélesedési profiljával; ez utóbbit úgy határoztuk meg, hogy a spektrállámpa emissziós vonalaira Gauss-görbét illesztettünk. A 6.1. ábrán egy szintetizált spektrumot hasonlítok össze az EW Scuti megfigyelt spektrumával. Az ábrán látható modellspektrumhoz felhasznált egyéb paramétereket a 6.1. táblázat alapján állítottuk be.

Az egyezés az ábra alapján egész jónak mondható, leszámítva azt, hogy néhány gyenge vonal esetén az illeszkedés nem teljesen jó. Ennek az az oka nagy valószínúséggel, hogy a log $g f$ értékei a Kurucz-féle vonallistában nem voltak az általunk használt $\log g f$ értékekhez igazítva, amelyeket az abundanciaanalízis során használtunk. Ez a teszt azt is jól szemlélteti, hogy a vasvonalak erősségei és két független kóddal (SPECTRUM ill. ATLAS9) számolt abundanciák általában konzisztensek.

A csillag forgása és/vagy a pulzációja szintén megváltoztatja a spektrumokban található vonalprofilokat, ezért az abundanciaanalízisre gyakorolt hatását mindenképpen meg kell vizsgálni. Ezek 
a makroszkopikus mozgások konvolálják a helyi vonalprofilt a csillag látható felszínérôl származó vonalakkal, tehát a megfigyelt (integrált) vonal ezért kiszélesedik és egyre sekélyebbé válik. Elsô megközelítésként, a megfigyelt vonal teljes ekvivalens szélessége (EW) nem változik, mert a teljes abszorbeált fluxus megmarad. Vannak azonban másodrendú hatások, például az ekvivalens szélessége (EW) mérése során a megfigyelt spektrumok véges felbontással és jel/zaj viszonnyal rendelkeznek. Ezek a másodrendú hatások az ekvivalens szélessége (EW) méréseibe bizonyos szisztematikus bizonytalanságokat vezethetnek be, és ezeket a hatásokat mindenképpen figyelembe kell venni. Ezért megvizsgáltuk, hogy a programcsillagok esetében a forgás, vagy a pulzáció okoz-e az eredményben bármilyen szignifikáns eltérést. Az eredmény az lett, hogy egyik mozgásforma sem okoz az ekvivalens szélessége (EW) értékeinkben különösebb eltérést.

A cefeidák lassú rotátorok, hasonlóan a többi szuperóriáshoz. A megfigyelések alapján az egyenlítői sebességük látóirányba eső komponensének átlagértéke $\left(\left\langle v_{\mathrm{e}} \sin i\right\rangle\right)$ tipikusan $\sim 10 \mathrm{~km}$ $\mathrm{s}^{-1}$ vagy ennél kisebb (De Medeiros et al., 2002). Mivel a hosszabb periódussal pulzáló cefeidák nagyobb méretúek, az ilyen csillagok lassabban forognak, mint rövid periódusú társaik (Nardetto et al.,2006). Takeda és mtsai. (1997) a rövid periódusú SU Cas cefeida vizsgálatából azt találták, hogy a $\left\langle v_{\mathrm{e}} \sin i\right\rangle=0$-nak adódott, ami azt illusztrálja, hogy még a a legrövidebb pulzációs periódusú cefeidák között is vannak nagyon lassan forgó csillagok. Buchler \& Szabó (2007) elméleti úton tanulmányozta a forgás hatását a beat cefeidák periódusarányára. Azt találták, hogy a periódusarány erősen függ a nehéz elemek abundanciájától, de gyakorlatilag érzéketlen a forgásra.

A programcsillagaink rotációs sebességének becsléséhez meghatároztuk néhány gyenge vonal félértékszélességét (FWHM). Ehhez pár olyan vonalat kerestünk, amelyek csak minimális átfedést (blend-et) mutattak más közeli vonalakkal (Fe I $\lambda$ 6056, 6096, 6157, 6165 ^), és ezeket összehasonlítottuk különböző rotációs sebességekkel $\left(0,5,10,15\right.$, and $\left.20 \mathrm{~km} \mathrm{~s}^{-1}\right)$ szintetizált ATLAS9 modellspektrumokkal (a többi paraméter értékéül $T_{\text {eff }}=5750 \mathrm{~K}, \log g=1$, 5 , és $v_{t}=4,2 \mathrm{~km} \mathrm{~s}^{-1}$-t használtunk). Eredményül azt kaptuk, hogy a rotációs sebesség megnövelése nem változtatja meg a félértékszélességeket jelentôsen. Így a továbbiakban a modellszámításoknál a rotációt elhanyagoltuk, hiszen a az összes vizsgált csillagunk a lassú rotátorok közé sorolható, $\left\langle v_{\mathrm{e}} \sin i\right\rangle<20 \mathrm{~km}$ $\mathrm{s}^{-1}$ (6.1. táblázat).

Mivel a rotáción kívül a pulzáció is vonalkiszélesedést eredményez, a pulzációt nem tartalmazó modellspektrumok összevetése a megfigyelésekkel a forgási sebességek szisztematikus felülbecslését okozhatja. Emiatt a becsült $\left\langle v_{\mathrm{e}} \sin i\right\rangle$ értékek valójában felső korlátai a valódi forgási sebességnek. A pulzáció hatásának figyelembe vételéhez olyan félértékszélességú modellt használtunk, amelyhez $+20 \mathrm{~km} \mathrm{~s}^{-1}$ pulzációs sebességet adtunk (a rövid periódusú cefeidák esetében ez egy tipikus érték), majd az így kapott elméleti spektrumból újra kiszámítottuk a vizsgált vonalak félértékszélességét. Végezetül azt kaptuk, hogy ez a tipikus pulzációs sebesség $\mathrm{kb}$. $\sim 5 \mathrm{~km} \mathrm{~s}{ }^{-1}$-mal nagyobb becslést eredményez a $\left\langle v_{\mathrm{e}} \sin i\right\rangle$ rotációs sebességre, ami nagyjából megegyezik a becsült forgási sebességek $\left(\sim 3 \mathrm{~km} \mathrm{~s}^{-1}\right)$ bizonytalanságával. Fontos megjegyezni, hogy a FEROS instrumentális kiszélesedési profiljának félértékszélessége $\sim 0,15 \AA$ A, ami eleve $\sim 7 \mathrm{~km} \mathrm{~s}^{-1}$ rotációs 
sebességnek felel meg 6000 Ånél. Az ennél kisebbnek adódó $\left\langle v_{e} \sin i\right\rangle$ rotációs sebességek nem tekinthetőek szignifikánsnak.

Összességében úgy találtuk, hogy a forgás és a pulzáció hatása a modellek ekvivalens szélességére $1 \%$, ha a rotációs sebesség $v_{\text {rot }}=20 \mathrm{~km} \mathrm{~s}^{-1}$, és kevesebb, mint $0,1 \%$, ha a pulzációs sebesség $v_{\text {pul }}=20 \mathrm{~km} \mathrm{~s}^{-1}$. Ezek a számok mutatják, hogy a rotáció hatása a vonalak ekvivalens szélességére és a korábban bemutatott abundanciákra elhanyagolható.

A pulzáció ugyan nem változtatja meg a vonal ekvivalens szélességét, ellenben a légköri paraméterek $\left(T_{\mathrm{eff}}, \log g\right)$ megváltoznak a pulzációs ciklus során. A 6.1. táblázatban feltüntetett értékek azonban azt mutatják, hogy a kiszámolt abundanciák változása jellemzően kisebb, mint az egyedi abundanciák hibái, amelyeket fôként az atomi adatok és a modellatmoszférák bizonytalanságai okoznak. Mindezek alapján megállapíthatjuk, hogy habár a pulzáló csillagok esetében a légköri paraméterek meghatározása bonyolultabb, mint a statikus csillagok esetén, a különböző pulzációs fázisokban elvégzett független abundancia-analízisből származó fémességek konzisztensek egymással. Így valószínúsíthető, hogy a csak egy pulzációs fázisban megfigyelt csillagok spektrumából meghatározott fémességek sem terheltek a pulzációs fázistól függő jelentős szisztematikus hibával.

Az általunk megvizsgált csillagokból öt esetben (EY Car, V458 Sct, GSC8607-0608, GSC86911294, V1048 Cen) mi határoztunk meg elsőként spektroszkópiai [Fe/H] értéket (6.2. táblázat). Mivel a programcsillagaink nagy részére már volt korábban publikált fémesség, ezért mindenképpen nagyon fontos az általunk kapott értékek összevetése ezekkel az adatokkal. A korábban megjelent fémességértékek a [Fe/H]-ra a 6.2. táblázatban vannak összefoglalva.

A 6.2. ábrán az irodalmi $[\mathrm{Fe} / \mathrm{H}]$ értékeket az általunk meghatározott értékekhez viszonyítva ábrázoljuk. Az új [Fe/H] adataink bizonytalanságai a 0,1-0,2 dex (6.2. táblázat).

Az adatokat összevetve azt tapasztaltuk, hogy a mi értékeinkhez képest az Andrievsky et al. (1994) által megadott fémességértékek szisztematikusan kisebbek. Ennek oka nagy valószínúséggel az lehet, hogy a számítások során nullpontnak a Nap fémességét ôk 7,51-nek vették, míg mi a modellezés alapján 7,49-nek. Így az eltérés egyik oka valószínúleg modellezés és a számítás során felhasznált különböző bemeneti adatokból adódik. Ezenkívül az általuk használt színképek spektrális felbontása is alacsonyabb volt, mint a miénk, tehát a hibák eleve nagyobbak $(\sim 0,3$ dex $)$, mint a mi új méréseink bizonytalansága.

Másfelől az Andrievsky et al. (2002) által írt cikkben megjelent újabb [Fe/H] adatok sokkal jobb egyezést mutatnak az mi méréseinkkel, bár a két mintában csak 5 közös csillag van. Úgy véljük, hogy azok a késôbbi (független) adatok növelik a valószínúségét annak, hogy a mi adataink közelebb vannak a csillagok valódi $[\mathrm{Fe} / \mathrm{H}]$ értékeihez. Bár Andrievsky et al. (2002) nem határozták meg a $[\mathrm{Fe} / \mathrm{H}]$ értékeik hibáit, de megemlítik, hogy az általuk kapott abundancia átlagos bizonytalansága 0,05-0,2 dex, ami szinte megegyezik a mi adataink hibájával.

A D’Cruz et al. (2000) által publikált adatok szintén jó egyezést mutatnak a mi eredményeinkkel, az eltérések $1 \sigma$-nál kisebbek. D’Cruz et al. (2000) jóslatot is megadott a várható [Fe/H] 


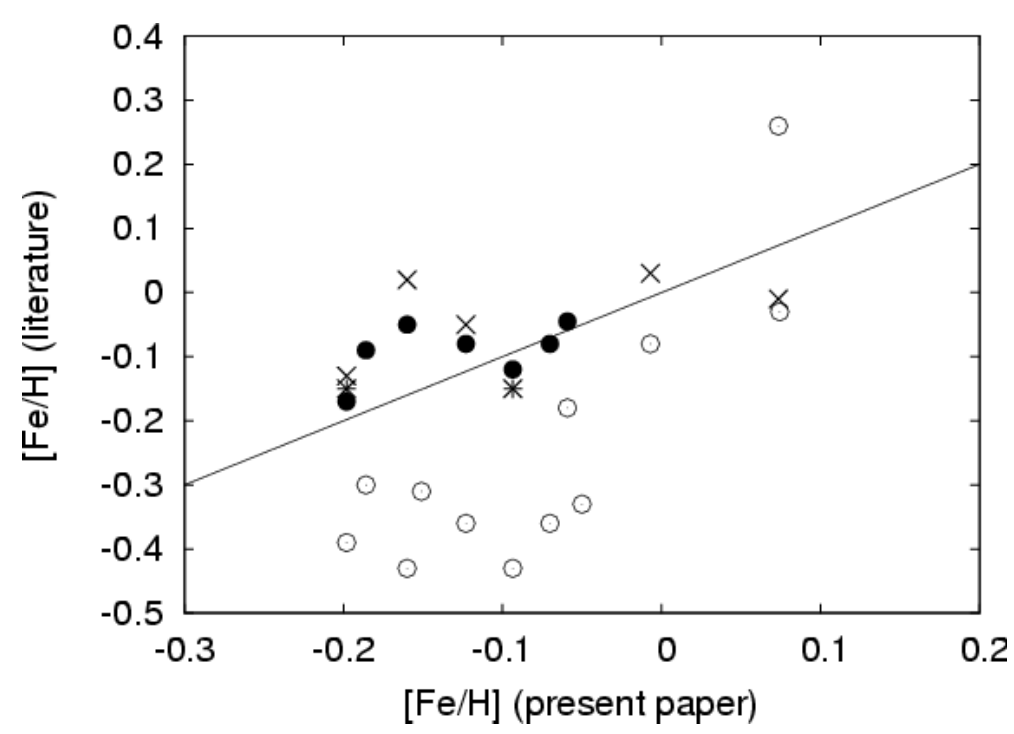

6.2. ábra. Az általunk meghatározott $[\mathrm{Fe} / \mathrm{H}]$ adatok összehasonlítása az irodalmi értékekkel (lásd a 6.2. táblázatban szereplő adatokat). A egyes szimbólumok jelentése: tele körök: D'Cruz et al. (2000); üres körök: Andrievsky et al. (1994); keresztek: Andrievsky et al. (2002); csillagok: Lemasle et al. (2007). Az Andrievsky et al. (1994) által megadott értékek és az általunk meghatározott eltéréseinek okait a dolgozatban részletezem.

értékre, amelyeket elméleti pulzációs modellekből számoltak ki. Sajnos nem adnak meg hibát az elméleti úton meghatározott $[\mathrm{Fe} / \mathrm{H}]$ értékeikhez, csak egy rövid megjegyzéssel utalnak arra, hogy elég pontosak lettek. A munkájukban szintén eltérést tapasztaltak a saját eredményük és Andrievsky et al. (1994) eredményei között. Összességében elmondhatjuk, hogy a 6.2. táblázatban látható adatok alapján, az ô adataik is hibahatáron belül megegyeznek a mi új spektroszkópiai abundanciáinkkal.

Végezetuil, Lemasle et al. (2007) cikkében szerepel még két olyan beat cefeida fémessége, amely a mi programcsillagaink között is jelen volt. Mindkét csillag esetében az eredmények jó egyezést mutatnak a mi és Andrievsky et al. (2002) cikkében található értékekkel.

A V1048 Cen (HD 304373) csillag esete különös figyelmet érdemel. A CO Aur csillaggal együtt ezek ketten a Tejútrendszerben található beat cefeidák közül az első és második felhangban (1O/2O) pulzáló kétmódusú csillagok közé tartoznak (Beltrame \& Poretti, 2002). A csillagok pozíciója a Petersen-diagramon nagyon hasonlít a többi Nagy-Magellán-felhôben lévô 1O/2O pulzátorokéhoz. Ez a hasonlóság érdekes, tekintve, hogy a tejútrendszerbeli és a Magellán-felhőkbeli F/1O pulzáló csillagok egy jól elkülönített szekvenciákat mutatnak a Petersen-diagramon (lásd a 6.3. ábrát Poretti \& Beltrame, 2004-ből).

Felmerülhet, hogy a V1048 Cen csillag (illetve a CO Aur is) fémessége esetleg eltérő lehet a többi kétmódusú cefeidához képest. Az általunk meghatározott értékek (6.2. táblázat) viszont arra utalnak, hogy hogy a V1048 Cen fémtartalma nagyon hasonlít a galaktikus F/1O cefeidák fémességéhez. Az mondhatjuk, hogy a kétmódusú pulzátorok esetében további vizsgálatokra van 

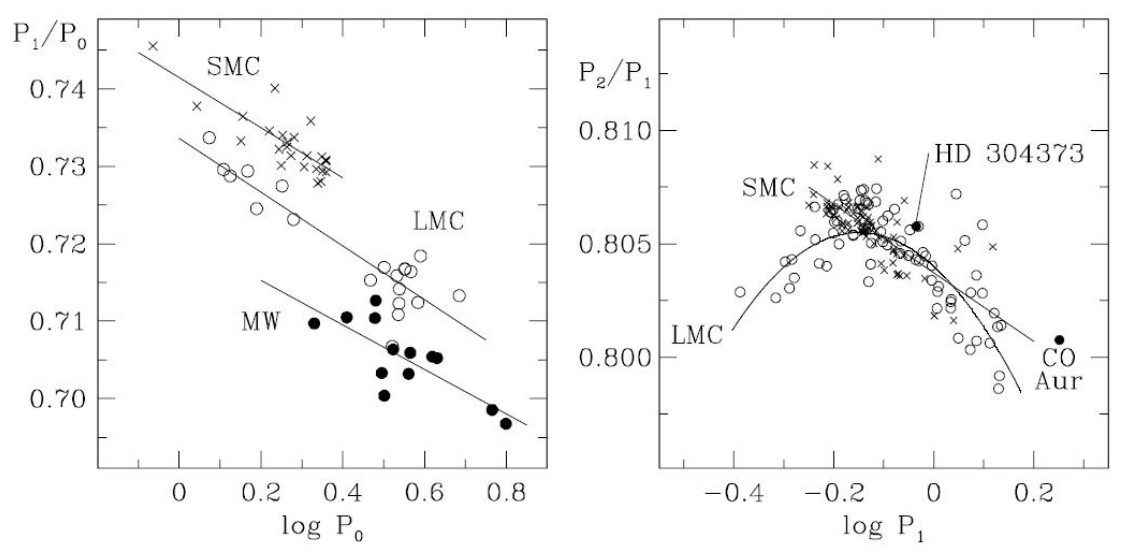

6.3. ábra. A Tejútrendszerben, illetve a Magellán-felhőkben található kétmódusú cefeidák Petersen- diagramja. A különböző galaxisokra jól szeparálódnak a $P_{0} / P_{1}$ pulzátorok, míg a $P_{2} / P_{1}$ periódusarány esetén ez nem igaz!

szükség annak magyarázatára, hogy pulzátorok két csoportja miért viselkedik különbözôképpen a különböző galaxisokban.

A tejútrendszerbeli beat cefeidák $[\mathrm{Fe} / \mathrm{H}]$ értékeinek spektroszkópiai meghatározásáról szóló cikkünk (Sziládi et al., 2007) után évekkel késôbb további két publikáció is megjelent hasonló témában (Chekhonadskikh, Kovtyukh \& Belik, 2014 és Kovtyukh et al., 2016). Az ezekben közölt adatokat átvizsgálva azt találtuk, hogy az általunk publikált fémességek szisztematikus eltérést mutatnak a két későbbi cikkben megjelent adatokhoz képest; az eltérés átlagos mértéke $\Delta[\mathrm{Fe} / \mathrm{H}] \sim-0,07$ dex. Az egységesítés érdekében a Kovtyukh et al. (2016)-ban szerepló értékeket nullpontnak véve a 3 cikkben szereplő adatokat összecsúsztattuk, ezzel a szisztematikus eltérést az adatokból kikorrigáltuk, majd az így kapott $[\mathrm{Fe} / \mathrm{H}]$ értékeket átlagoltuk. A munkánk további részében az így kapott homogenizált fémességadatokkal dolgoztunk.

A 6.3. táblázatban a legutóbbi 3 cikkben található fémességek vannak feltüntetve, a 6.4. táblázatban pedig a homogenizálás utáni $[\mathrm{Fe} / \mathrm{H}]$ értékek szerepelnek.

\subsection{A periódus - periódusarány - fémesség összefüggés}

A 2007-es cikkünkben az általunk meghatározott új [Fe/H] adatok lehetővé tették számunkra, hogy frissítsük a korábbi megfigyelésekből származó periódusarány-fémesség összefüggést, amelynek létét Andrievsky és munkatársai korábban már kimutatták (Andrievsky et al., 1993, 1994).

A 5.1. és 6.2. táblázatokban szereplő adatokat figyelembe véve az első ezzel a témával foglalkozó cikkünk (Sziládi et al., 2007) megírásakor a következő empirikus összefüggést találtuk: 
6.3. táblázat. A Tejútrendszer beat cefeidáinak újabban publikált $[\mathrm{Fe} / \mathrm{H}]$ értékei

\begin{tabular}{lrrr}
\hline Csillag & {$[\mathrm{Fe} / \mathrm{H}]^{a}$} & {$[\mathrm{Fe} / \mathrm{H}]^{b}$} & {$[\mathrm{Fe} / \mathrm{H}]^{c}$} \\
\hline TU Cas & 0,04 & $-0,16$ & 0,03 \\
VX Pup & $-0,08$ & $-0,20$ & $-0,06$ \\
AX Vel & $-0,05$ & $-0,09$ & $-0,05$ \\
AS Cas & $-0,19$ & - & - \\
GZ Car & 0,02 & $-0,07$ & 0,00 \\
AP Vel & 0,07 & $-0,06$ & 0,06 \\
BQ Ser & $-0,05$ & $-0,13$ & $-0,04$ \\
U TrA & $-0,09$ & $-0,15$ & $-0,07$ \\
BK Cen & 0,13 & 0,07 & 0,12 \\
V458 Sct & 0,11 & 0,09 & 0,09 \\
UZ Cen & $-0,03$ & $-0,19$ & $-0,02$ \\
EW Sct & 0,04 & $-0,01$ & 0,04 \\
EY Car & 0,04 & $-0,17$ & 0,07 \\
Y Car & 0,03 & $-0,05$ & 0,02 \\
V367 Sct & 0,07 & 0,075 & 0,05 \\
V1048 Cen & - & - & $-0,18$ \\
V701 Car & 0,06 & $-0,11$ & 0,07 \\
V1210 Cen & 0,03 & $-0,015$ & 0,08 \\
V371 Per & $-0,40$ & - & $-0,42$ \\
\hline${ }^{a}$ Kovtyukh et al., 2016 & & & \\
${ }^{2}$ Sziladi et al.,2007 & & & \\
${ }^{c}$ Chekhonadskikh et al., 2014 & & & \\
& & &
\end{tabular}


6.4. táblázat. A tejútrendszerbeli cefeidák homogenizált $[\mathrm{Fe} / \mathrm{H}]$ értékei

\begin{tabular}{lr|lr|lr}
\hline Csillag & {$[\mathrm{Fe} / \mathrm{H}]$} & Csillag & {$[\mathrm{Fe} / \mathrm{H}]$} & Csillag & {$[\mathrm{Fe} / \mathrm{H}]$} \\
\hline TU Cas & $-0,003$ & VX Pup & $-0,087$ & AX Vel & $-0,036$ \\
V901 Mon & $-0,100$ & AS Cas & $-0,190$ & GZ Car & 0,010 \\
DZ CMa & $-0,090$ & AP Vel & 0,050 & BQ Ser & $-0,047$ \\
U TrA & $-0,077$ & BK Cen & 0,133 & V458 Sct & 0,123 \\
BE Pup & $-0,180$ & UZ Cen & $-0,053$ & EW Sct & 0,050 \\
EY Car & $-0,007$ & Y Car & 0,027 & V367 Sct & 0,092 \\
\hline
\end{tabular}

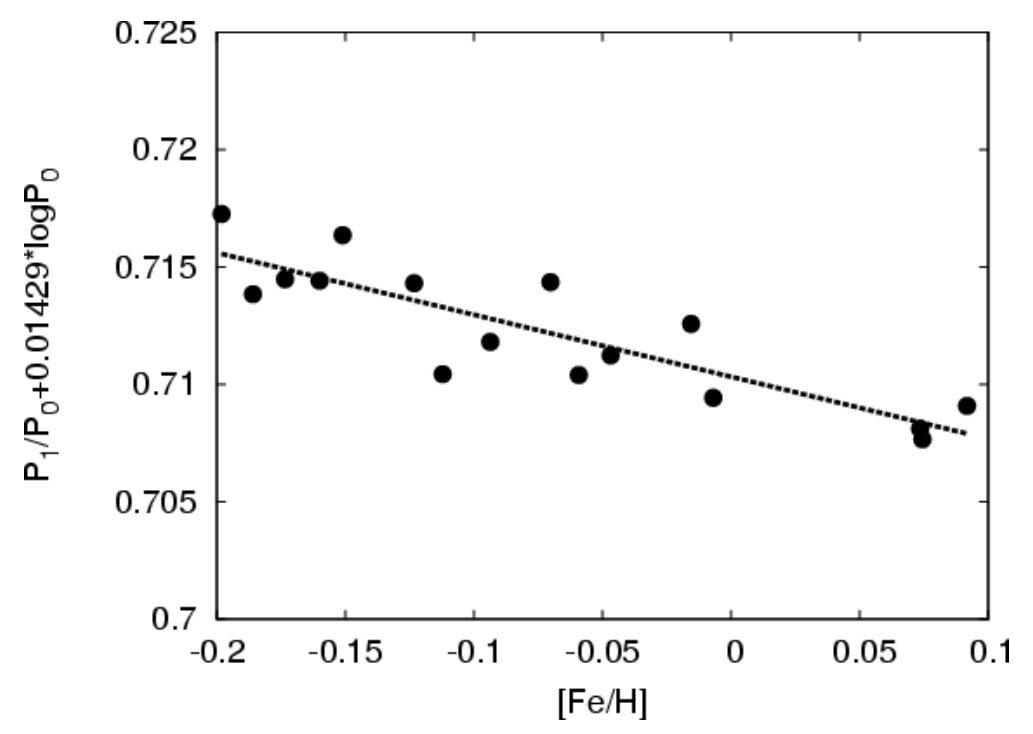

6.4. ábra. A periódusarány - fémesség összefüggés. A pontozott vonal a 6.3. egyenletből származik. A függóleges tengelyre vonatkozó korrekciós kifejezés leírása a szövegben megtalálható.

$$
\begin{aligned}
& P_{1} / P_{0}=-0,0143 \log P_{0} \quad-0,0265 \quad[\mathrm{Fe} / \mathrm{H}] \quad+0,7101 \\
& \pm 0,0025 \quad \pm 0,0044 \quad \pm 0,0014 \text {. }
\end{aligned}
$$

Mivel a periódusarány nemcsak a fémességtől, hanem az alapmódus periódusától is függ, ezért a 6.4. ábrán a függőleges tengelyen szereplő periódusarányt korrigáltuk az alapmódus periódusától való gyenge függéssel. Az így kapott diagram jól illusztrálja a $P_{1} / P_{0}$ periódusarány és a fémesség közötti korrelációt.

Az előző fejezetben már szóba került, hogy a 2007-ben megjelent cikkünkben publikált fémességértékeket felül kellett vizsgálnunk, ennek eredményeként új homogenizált fémtartalmakat határoztunk meg a galaktikus beat cefeidákra (lásd. 6.4. táblázat). Ez maga után vonta azt is, hogy a korábbi cikkünkben megjelent periódus-fémesség relációt is újra kellett számolnunk. A periódusarány - fémesség közötti összefüggés általános alakja a galaktikus beat cefeidákra a következőképpen írható fel:

$$
[\mathrm{Fe} / \mathrm{H}]=a \cdot \log P_{0}+b \cdot P_{1} / P_{0}+c
$$


A 2007-ben megjelent cikkben ezt a relációt a 6.3. egyenlet adta meg. A 6.3. egyenletet átrendezve, $a=-0,54 \pm 0,18, b=-37,74 \pm 1,69, c=26,80 \pm 0,95$ értékeket kaptunk. A cikk megjelenése után az összefüggést Chekhonadskikh, Kovtyukh \& Belik (2014) és Kovtyukh et al. (2016) is újrakalibrálta. Az általunk homogenizált új fémességeket figyelembe véve (6.4. táblázat), valamint a 6.5. és a 6.6. táblázatban található periódusidôket felhasználva a 6.4. egyenletet újraillesztettuik és a következő eredményt kaptuk: $a=-0,42 \pm 0,05, b=-24,73 \pm 1,35, c=17,67 \pm 0,95 . \mathrm{Az}$ illesztés során a $\sigma=0,035$-nek adódott, amit egyben a számított $[\mathrm{Fe} / \mathrm{H}]$ bizonytalanságának vettünk. A 6.5. ábra bal oldalán ábrázoltuk az eredményt, amit a periódusarány - fémesség relációra kaptunk a galaktikus beat cefeidák esetén. Megállapíthatjuk, hogy az újraszámolt relációnk jó egyezést mutat Chekhonadskikh, Kovtyukh \& Belik (2014) által korábban meghatározott értékekkel, $a=-0,58, b=-24,39, c=17,54$.
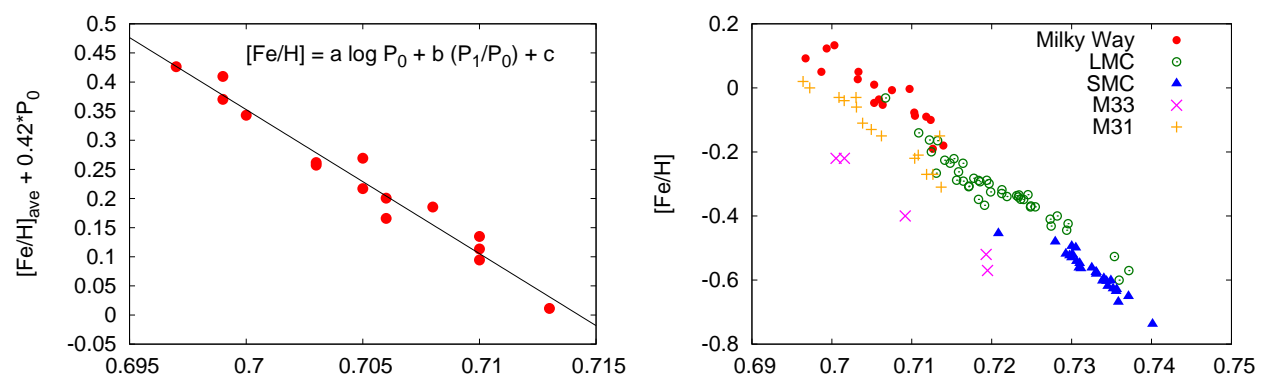

6.5. ábra. Bal oldal: a hơmơgenizált fémességekre illesztett új périódus-periódusarány-fémesség reláció (fekete vonal) a Tejútrendszer beat cefeidáira (tele körök). Jobb oldal: a teljes minta $[\mathrm{Fe} / \mathrm{H}]$ értékei (beleértve a Magellán-felhők, valamint az M31 és M33 extragalaxisok cefeidáit is) a $P_{1} / P_{0}$ periódusarány függvényében.

A 6.4. egyenletből a $a, b, c$ paraméterek ismeretében a Magellán-felhők beat cefeidáira is lehetôségünk nyílt egyedi fémességeket meghatározni. Ennek eredményét láthatjuk a 6.5. ábra jobb oldali részén. Ezen az ábrán a galaktikus és Magellán-felhőkbeli cefeidákon kívül az M33-ban található 5 beat cefeida (Beaulieu et al., 2006), valamint az M31-ben levő 15 kétmódusú cefeida (Lee et al., 2013) adatait is ábrázoltuk. Az M31 és M33 esetében a [Fe/H] értékeket az említett cikkekben található $\mathrm{Z}$ értékekből határoztuk meg a következő összefüggés alapján:

$$
[\mathrm{Fe} / \mathrm{H}] \approx \log _{10}\left(Z / Z_{\odot}\right)
$$

A 6.5. egyenletben szereplő $Z_{\odot}$ értéket Asplund et al. (2009) alapján 0,0134-nek vettuik. Végezetuil megállapíthatjuk, hogy mind az M31 és M33 beat cefeidáira fellép egy szisztematikus eltolódás a $[\mathrm{Fe} / \mathrm{H}]$ értékekben, de összességében hasonló tendenciát tapasztalunk, mint a Tejútrendszer és a Magellán-felhők esetében. Az ilyen jellegú szisztematikus eltolódás nem váratlan, mivel a Z fémességértékét ezen galaxisok $[\mathrm{O} / \mathrm{H}]$ méréséből becsülték meg, amely különböző fizikai feltevéseken és modelleken alapul. Lehetséges, hogy alulbecsüljük ezzel a módszerrel [Fe/H] értékeket. 
Az a tény, hogy minden galaxisra a 6.5. ábra ugyanazt a tendenciát mutatja, arra utal, hogy a 6.5. egyenlet egyöntetúen érvényes a vizsgált $-0,8<[\mathrm{Fe} / \mathrm{H}]<+0,2$ fémesség tartományban levő cefeidákra, függetlenül attól, hogy a csillag éppen melyik galaxisban helyezkedik el.

\subsection{Fotometriai fémességek kétmódusú cefeidákra}

A galaktikus beat cefeidák spektroszkópiai vizsgálatai után felmerült az ötlet, hogy nézzük meg annak a lehetőségét, hogy szimplán fotometriai adatokból tudunk-e valami előrejelzést adni ezen típusú csillagok fémességére. A meglévő spektroszkópiai adataink mellé összegyưjtöttük a különböző forrásokból elérhető fotometriai adatokat. Nagy részét megtaláltuk az All Sky Automated Survey 3 (ASAS-3) ${ }^{1}$ égboltfelmérô projekt katalógusában (Pojmański, 2009). Volt pár olyan csillagunk is (AS Cas, BE Pup, CO Aur, TU Cas, U TrA), amelyekre nem találtunk az ASAS-3 katalógusban fellelhetô adatot, így esetükben a közelmúltban publikált mérésekből próbáltunk összeszedni használható fénygörbéket. Legtöbbjüket Berdnikov (2008) kiterjedt adatbázisából vettük át, kivéve a TU Cas és a BQ Ser csillagokat, amelyekről konzulensem, Szabados László bocsátott rendelkezésemre további méréseket. Így ezek a csillagok is benne maradhattak a mintában a további vizsgálatokhoz. Így összesen 18 galaktikus beat cefeidát tartalmazott a végsô mintánk.

A Fourier-paramétereket a V szűrôvel készült fénygörbékre történő illesztéssel határoztuk meg. Az illesztés során az előző a 3.24. egyenlet használtuk fel. Az illesztés eredményeként meghatározott paramétereket az alapmódusra a 6.5. táblázat mutatja, az első felhangra kapott eredményeket pedig a 6.6. táblázat tartalmazza. A táblázatokban az alapmódushoz tartozó periódusidő szerint növekvő sorrendben szerepelnek a csillagok.

Miután a galaktikus cefeidákra elvégeztuik az illesztést, a módszert szerettük volna kiterjeszteni a Magellán-felhők kétmódusú cefeidáira is. A Magellán-felhők beat cefeidáinak fotometriai adatait, mind a Nagy-Magellán-felhő, mind a Kis-Magellán-felhő esetében, a változócsillagok adatait tartalmazó OGLE adatbázisából töltöttük le (Soszyński et al., 2015, 2017). Az előző fejezetek között részletes leírás található erről a felmérô programról. A vizsgálatunk során az OGLE-III, illetve OGLE-IV projektfázisban mért, alapmódusban és első felhangban pulzáló beat cefeidák fénygörbéit használtuk fel. Ezekrôl a csillagokról V, illetve I szúrôvel készült fénygörbéket találtunk az adatbázisban, hasonlóan a előzóekben már vizsgált galaktikus beat cefeidák fotometriai adataihoz.

A Fourier-paraméterek meghatározásához végül az OGLE I szűrővel készült fénygörbéit használtuk fel. Ennek a fô oka az volt, hogy az I szûrős megfigyelések száma sokkal nagyobb volt, mint a V-szúrôvel készülteké. A V, illetve I szúrôvel készült fénygörbék amplitúdóit megvizsgálva azt tapasztaltuk, hogy a két különbözô szúrôvel készült fénygörbe amplitúdói átlagosan egy 1,7-es szorzótényezôvel különböznek. Így az I szúrôvel készült fénygörbéket ezzel a faktorral korrigálva hasonló Fourier-amplitúdókat kaphattunk, mintha a V-szúrôs fénygörbéket vizsgáltuk volna. A korrekciót követően a V- és I-szúrős fénygörbék Fourier-amplitúdói jól illeszkednek, de a $\varphi_{21}$ és

\footnotetext{
${ }^{1} \mathrm{http}: / /$ www.astrouw.edu.pl/asas/?page $=$ aasc $\&$ catsrc $=$ asas3
} 
6.5. táblázat. A Tejútrendszerben található kétmódusú cefeidák Fourier-paraméterei (alapmódus)

\begin{tabular}{lcccccc}
\hline Star & $P_{0}$ & $A_{1}$ & $R_{21}$ & $\varphi_{21}$ & $R_{31}$ & $\varphi_{31}$ \\
\hline TU Cas & 2,139280 & 0,2887 & 0,3337 & 4,1153 & 0,1312 & 2,1588 \\
V901 Mon & 2,265600 & 0,0611 & 0,3595 & 2,0804 & 0,2146 & 4,8647 \\
DZ CMa & 2,311050 & 0,2546 & 0,3184 & 4,3204 & 0,1099 & 2,1675 \\
U TrA & 2,568670 & 0,2590 & 0,3138 & 4,2206 & 0,1462 & 1,7548 \\
BE Pup & 2,865710 & 0,2269 & 0,3555 & 4,2177 & 0,0493 & 3,1266 \\
EY Car & 2,875860 & 0,2026 & 0,2892 & 4,0958 & 0,1086 & 2,2819 \\
VX Pup & 3,011640 & 0,1733 & 0,1734 & 3,9728 & 0,0443 & 1,4934 \\
AS Cas & 3,024236 & 0,2121 & 0,3016 & 4,3097 & 0,1167 & 2,3555 \\
AP Vel & 3,127785 & 0,2758 & 0,2829 & 4,1553 & 0,1014 & 2,0899 \\
BK Cen & 3,173670 & 0,2520 & 0,2643 & 4,1724 & 0,1107 & 2,3413 \\
UZ Cen & 3,334390 & 0,2875 & 0,3455 & 4,1823 & 0,1424 & 2,0904 \\
Y Car & 3,639790 & 0,2603 & 0,2749 & 4,1469 & 0,1047 & 2,2067 \\
AX Vel & 3,673380 & 0,1034 & 0,1318 & 3,8030 & 0,0794 & 5,9420 \\
GZ Car & 4,159080 & 0,1392 & 0,1958 & 4,4774 & 0,1146 & 3,8867 \\
BQ Ser & 4,271170 & 0,1765 & 0,1537 & 4,3171 & 0,0758 & 1,6807 \\
V458 Sct & 4,840760 & 0,0784 & 0,1066 & 4,5073 & 0,1230 & 3,2047 \\
EW Sct & 5,823090 & 0,1463 & 0,2395 & 4,2569 & 0,0875 & 1,4816 \\
V367 Sct & 6,293820 & 0,1884 & 0,1905 & 4,5298 & 0,0370 & 3,3742 \\
\hline
\end{tabular}

6.6. táblázat. A Tejútrendszerben található kétmódusú cefeidák Fourier-paraméterei (első felhang)

\begin{tabular}{lcccccc}
\hline Star & $P_{1}$ & $A_{1}$ & $R_{21}$ & $\varphi_{21}$ & $R_{31}$ & $\varphi_{31}$ \\
\hline TU Cas & 1,518300 & 0,1056 & 0,1057 & 3,9136 & 0,1041 & 1,6562 \\
V901 Mon & 1,613940 & 0,0680 & 0,0938 & 3,7651 & 0,3790 & 4,1571 \\
DZ CMa & 1,645020 & 0,1381 & 0,0688 & 4,8583 & 0,0385 & 0,1132 \\
U TrA & 1,824550 & 0,1381 & 0,0688 & 4,8583 & 0,0385 & 0,1132 \\
BE Pup & 2,045960 & 0,1327 & 0,1204 & 4,8092 & 0,0329 & 0,7719 \\
EY Car & 2,034720 & 0,0311 & 0,1645 & 3,1249 & 0,1896 & 1,7091 \\
VX Pup & 2,139460 & 0,1408 & 0,1476 & 4,5633 & 0,0627 & 3,9216 \\
AS Cas & 2,155172 & 0,1199 & 0,1483 & 4,4286 & 0,0860 & 1,1605 \\
AP Vel & 2,199840 & 0,1397 & 0,1549 & 4,4142 & 0,0327 & 3,0393 \\
BK Cen & 2,222570 & 0,0878 & 0,1915 & 4,5368 & 0,0903 & 2,4259 \\
UZ Cen & 2,355260 & 0,0816 & 0,0728 & 4,3039 & 0,0716 & 5,7085 \\
Y Car & 2,559630 & 0,1187 & 0,0949 & 4,8725 & 0,0130 & 3,2620 \\
AX Vel & 2,592990 & 0,1416 & 0,0457 & 5,4459 & 0,0181 & 4,1466 \\
GZ Car & 2,933350 & 0,0688 & 0,0272 & 3,2913 & 0,1064 & 0,4308 \\
BQ Ser & 3,012440 & 0,1048 & 0,0732 & 5,4045 & 0,0135 & 2,9519 \\
V458 Sct & 3,385380 & 0,1539 & 0,0945 & 3,2936 & 0,0434 & 4,2539 \\
EW Sct & 4,068510 & 0,1027 & 0,1306 & 0,7595 & 0,0264 & 5,2577 \\
V367 Sct & 4,384960 & 0,1215 & 0,0873 & 4,4093 & 0,0578 & 2,3662 \\
\hline
\end{tabular}

$\varphi_{31}$ fázisok meghatározásához a megbízhatóság megôrzése érdekében csak az I-szúrôs fotometriai adatokat használtuk fel.

Az adatbázisban megtalálható beat cefeida adatok közül csak azokat hagytuk benne a vizsgált 
csillagok csoportjában, amelyeknek az amplitúdója $A_{1}>0,05$ mag volt. Így a vizsgálat során a Nagy-Magellán-felhő esetén 56, a Kis-Magellán-felhő esetén pedig 42 (összesen 98) beat cefeida fénygörbéje került felhasználásra.

A 6.6. és a 6.7. ábra a teljes minta Fourier-paramétereit mutatja: a piros pontok a Tejútrendszer, a zöld pontok a Nagy-Magellán-felhő, a kék pontok pedig a Kis-Magellán-felhő beat cefeidáinak adatait jelölik. Az ábrákon az meghatározott Fourier-paramétereket látjuk a a $P_{1} / P_{0}$ periódusarány függvényében.
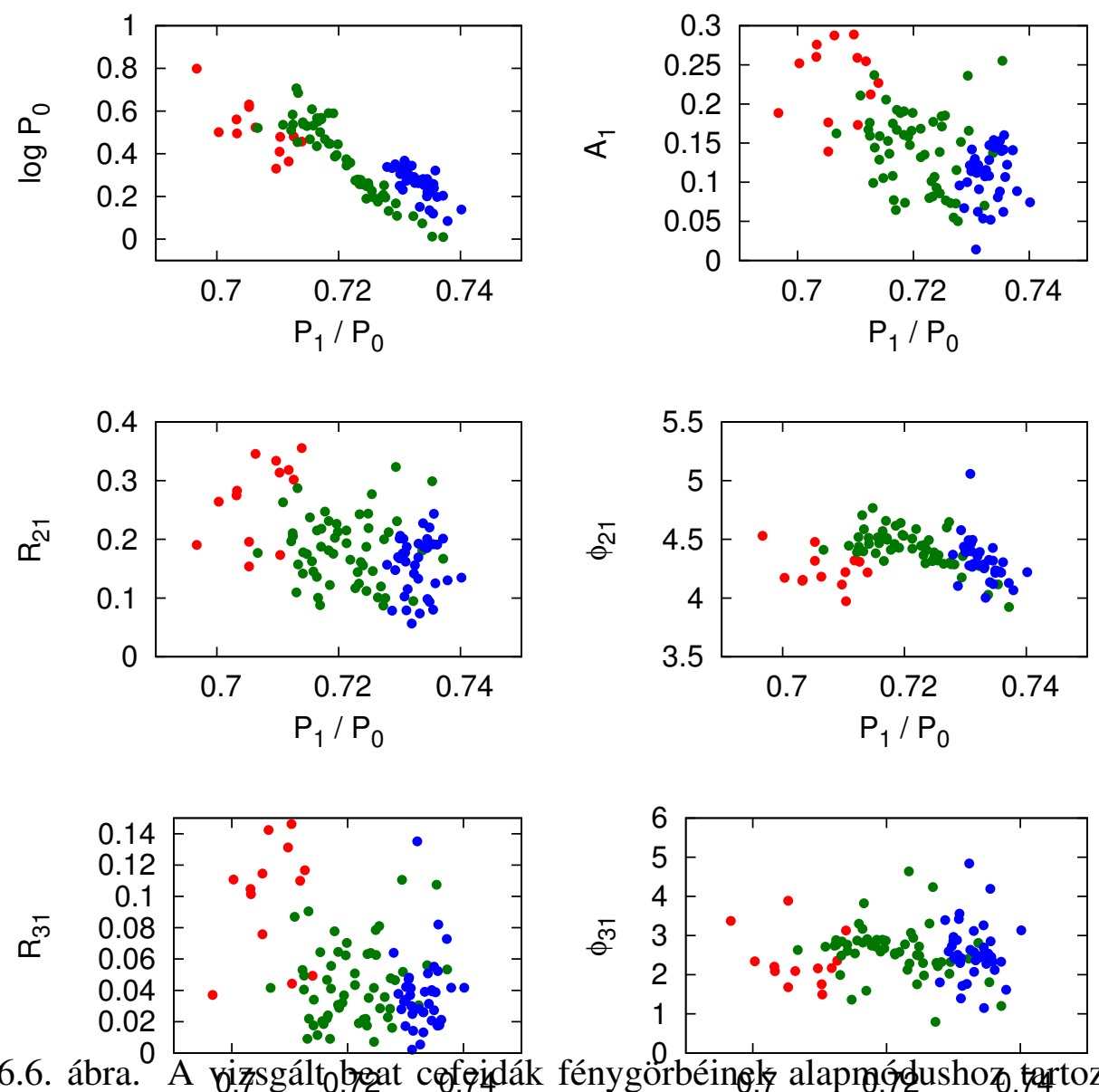
$P_{1} / P_{0}$ periódusaránypfuijggvényében ábrázolva. Az ábrázøláspsorán a piros pontok a Tejútrendszerben, a zöld pontok a Nagy-Magellán-felhőben és a kék pontok a Kis-Magellán-felhőben található csillagokat jelölik.

A Fourier-paraméterek meghatározása után, illetve a Magellán-felhőkben található beat cefeidák fémességének kiszámítása után a célunk az volt, hogy meg tudjunk adni egy olyan általános összefüggést, amely lehetôvé teszi, hogy csupán a csillag fénygörbéjének ismerete alapján a kétmódusú cefeidák fémességére megbízható becslést tudjunk tenni. Ehhez meg kellett keresnünk 

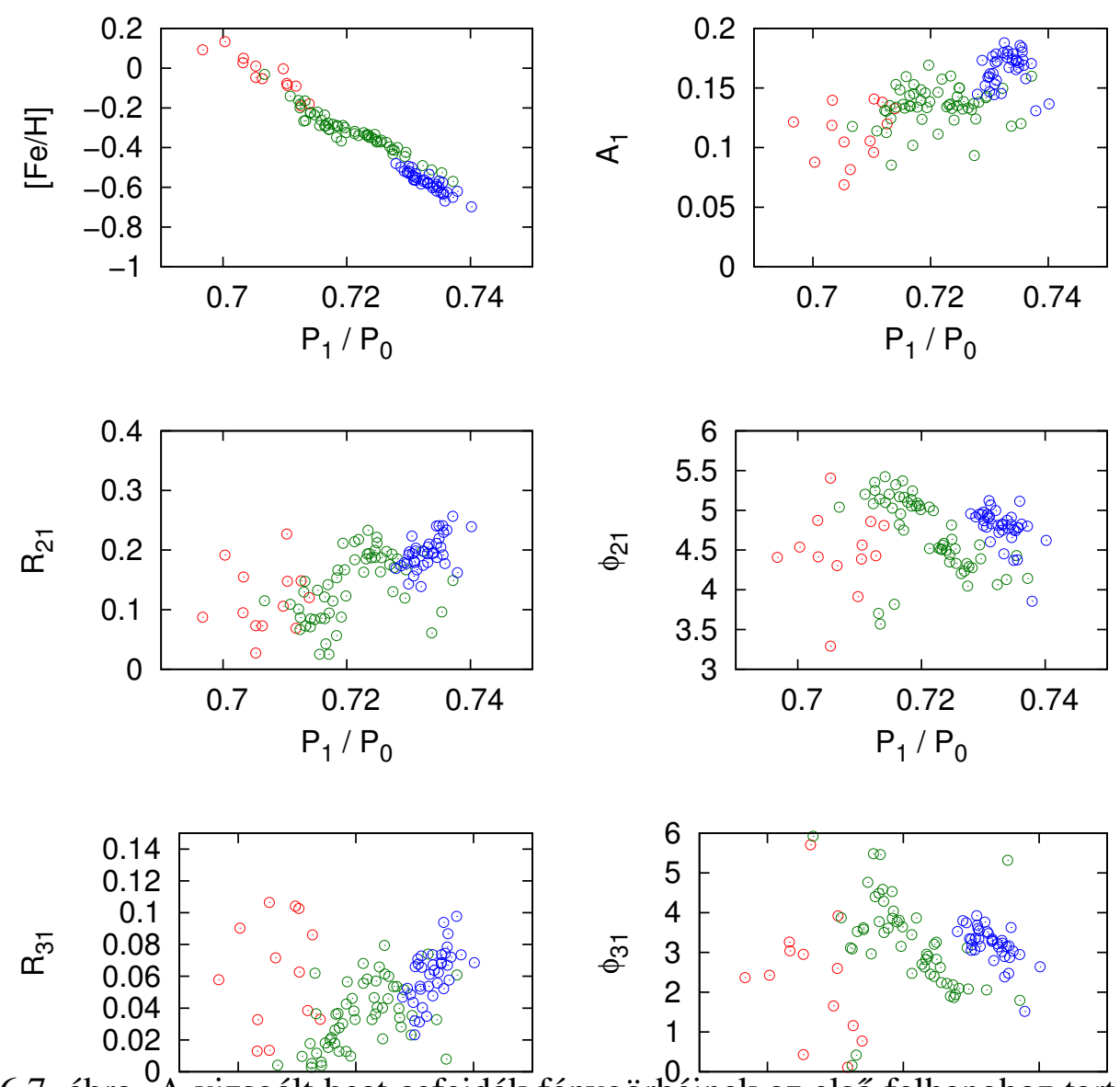

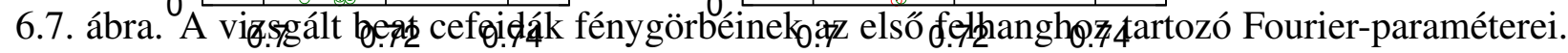
Az ábrázolás teljeserp azpnos a 6.6. ábránál alkalmazott jẹ̣lø̈késekkel. A bal felsô panel a homogenizált $[\mathrm{Fe} / \mathrm{H}]$ értékeket mutatja, szintén a $P_{1} / P_{0}$ periódusarány függvényében.

a legpontosabb korrelációt a fénygörbe alakja és a fémesség között. Ennek érdekében az alábbi lineáris függvényt illesztettük az adatainkra:

$$
[\mathrm{Fe} / \mathrm{H}]=c_{0}+c_{1} A_{1}+c_{2} R_{21}+c_{3} \varphi_{21}+c_{4} R_{31}+c_{5} \varphi_{31}
$$

Az RR Lyrae csillagok esetében a Fourier-paraméterek meghatározására Kovács \& Zsoldos (1995) egy korábbi cikkében összetettebb modellt adott meg, amely tartalmazta az egyes paraméterek szorzatát is, pl. $A_{3} \cdot \varphi_{31}$. A mi esetünkben használt megközelítés jobban hasonlít a Jurcsik \& Kovács (1996) által alkalmazott módszerhez, azzal az eltéréssel, hogy a 6.6. egyenletben leírt modell több paramétert tartalmaz az esetünkben.

Az adatainkra két lépésben alkalmaztuk a 6.6. egyenletet. Először a Tejútrendszerben, a NagyMagellán-felhőben, illetve a Kis-Magellán-felhőben található beat cefeidák adatait külön-külön 
illesztettük. Mivel a három részminta csoport fémessége lényegesen különbözik egymástól, ez az eljárás így még mindig magába hordozhatja a $c_{\text {i }}$ paraméterek fémességtől való függését is. Így ezt kizárandó, második lépésként, összeolvasztottuk a három adathalmazt, és erre az összevont adathalmazra illesztettük a 6.6. egyenlet egyidejüleg. Végül az alapmódushoz tartozó Fourierparaméterek ismeretében, mindkét lépést megismételtük az első felhang paramétereinek meghatározására.
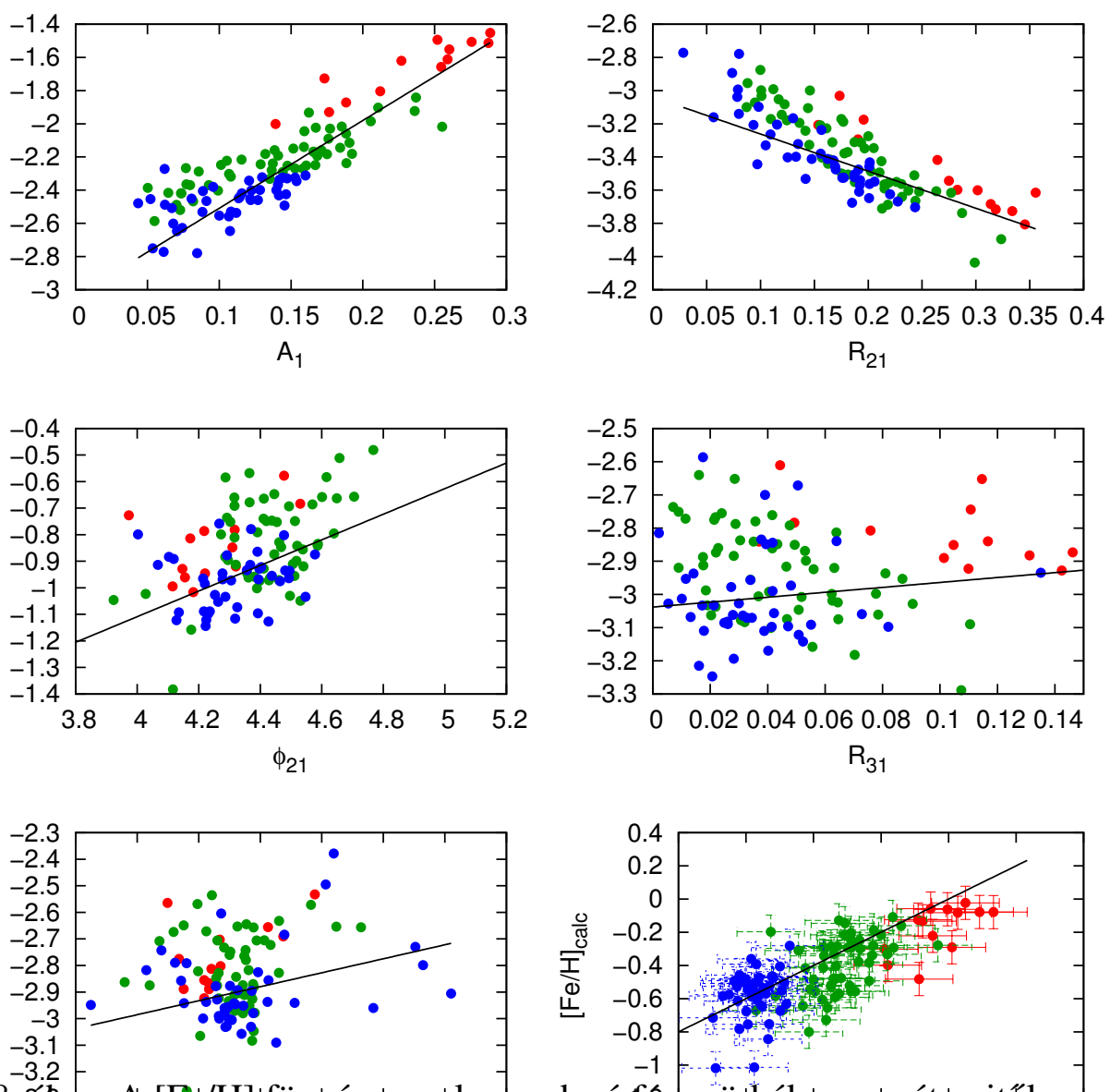

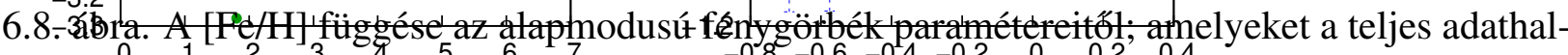

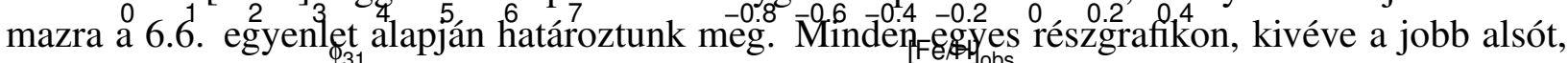
az x tengelyen egy adott Fourier-paramétert mutat, míg az y tengely a 6.6 egyenlet átrendezett formája, az x tengelyen szereplő paramétert kivéve az összes többi Fourier-paramétert a bal oldalra rendezzük. A jobb alsó panel a bemeneti $[\mathrm{Fe} / \mathrm{H}]$ értékek függvényében ábrázolja a lineáris modell alapján számított $[\mathrm{Fe} / \mathrm{H}]$ értékeket.

A 6.8. ábra az általunk vizsgált összes (mind 3 galaxis) beat cefeidáinak a fénygörbéjére illesztett korrelációs eredményeket szemlélteti. Minden egyes panelben az x tengelyen egy adott Fourier-paraméter van feltüntetve, amelynek függvényében az y tengelyen a 6.6. egyenlet átrendezett formáját ábrázoljuk (az ábrázolt Fourier-paraméter kivételével az összes többit a másik oldalra 

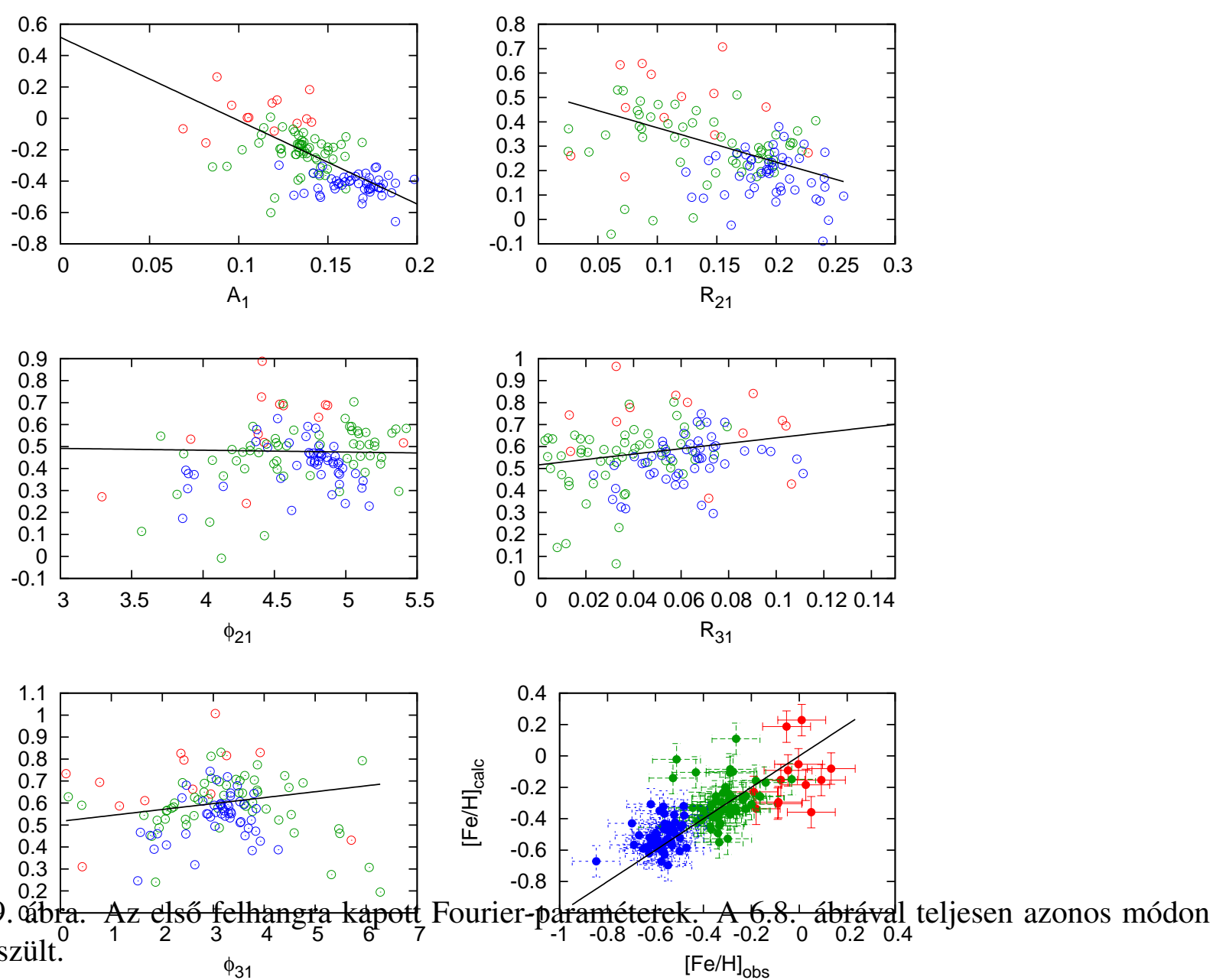

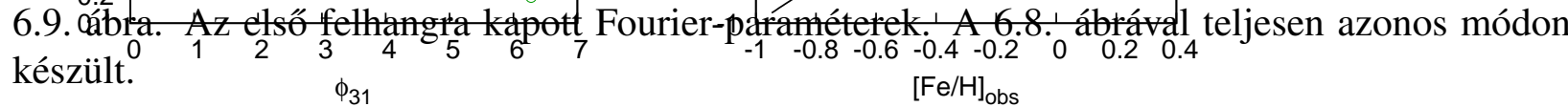

rendeztük). A jobb alsó panelen a bemeneti $[\mathrm{Fe} / \mathrm{H}]$ értékeket vetettük össze az újonnan kiszámított fémességekkel. A $[\mathrm{Fe} / \mathrm{H}]$ értékek összehasonlítását szemléltető ábrán mindkét értékre 0.1 dex bizonytalanságot feltételeztünk. Látható, hogy kis szórástól eltekintve a bemeneti és kimeneti fémességek között meglehetôsen jó egyezést kaptunk. Az adathalmazunk Pearson-korrelációs együtthatója 0,822, ami a várt módon erôs korrelációt jelez. Az átlagos szórás 0,114 dex.

Ugyanezt megnézve az első felhang paramétereire, nagyon hasonló eredményt kaptunk. A fémességek esetén a $[\mathrm{Fe} / \mathrm{H}]_{\mathrm{obs}}-[\mathrm{Fe} / \mathrm{H}]_{\text {calc }}$ függvény szórása szintén kicsi, 0,115 dex, de a Pearsonkorrelációs együttható némileg alacsonyabb, 0,775 lett. Az első felhangra kapott eredményeket a 6.9. ábrán mutatjuk be.

Klagyivik et al. (2013) egy egyszerúbb lineáris kapcsolatot feltételezett az amplitúdóarány $\left(R_{21}\right.$ vagy $\left.R_{31}\right)$ és a $[\mathrm{Fe} / \mathrm{H}]$ értéke között a rövid periódusú galaktikus cefeidák esetében. Azt jósolták, hogy az alacsonyabb fémtartalmú galaxisokban, mint például a Magellán-felhôk is, a cefeidák amplitúdóarányának nagyobbnak kell lenniük, mint a Tejútrendszerben. Összehasonlítva 
6.7. táblázat. A lineáris modell illesztéséből származó eredmények

\begin{tabular}{lrrrr}
\hline \multicolumn{5}{c}{ Alapmódushoz tartozó eredmények } \\
$c_{0}$ & 0,4267 & $-2,1279$ & $-1,6933$ & $-3,0380$ \\
$c_{1}$ & 3,0545 & 1,3928 & $-0,9309$ & 5,2892 \\
$c_{2}$ & $-2,6782$ & $-1,5316$ & 0,6588 & $-2,2372$ \\
$c_{3}$ & $-0,1956$ & 0,3983 & 0,2567 & 0,4823 \\
$c_{4}$ & 0,7717 & 1,3498 & $-0,4316$ & 0,7410 \\
$c_{5}$ & 0,1374 & 0,0309 & 0,0079 & 0,0526
\end{tabular}

\begin{tabular}{lrrrr}
\multicolumn{5}{l}{ Első felhanghoz tartozó eredmények } \\
$c_{0}$ & 2,3031 & $-0,9384$ & 0,1090 & 0,5167 \\
$c_{1}$ & $-4,1954$ & $-1,7904$ & $-0,3815$ & $-5,3130$ \\
$c_{2}$ & $-0,7759$ & 0,5281 & 0,3251 & $-1,4088$ \\
$c_{3}$ & $-0,3303$ & 0,1743 & $-0,1901$ & $-0,0083$ \\
$c_{4}$ & $-2,3568$ & $-1,5822$ & $-1,3270$ & 1,2303 \\
$c_{5}$ & $-0,0115$ & 0,0036 & 0,0972 & 0,0269 \\
\hline
\end{tabular}

az általunk meghatározott fémességeket és az amplitúdóarányokat a Klagyivik et al.(2013) által cefeidákra definiált lineáris modellel, azt kell megállapítanunk, hogy az a modell nem múködik a beat cefeidák esetében, sem a Tejútrendszer, sem a Magellán-felhők esetén (6.10. ábra). Az általunk megadott bonyolultabb modell azonban meg tudja becsülni megbízhatóan a $[\mathrm{Fe} / \mathrm{H}]$ értékeket a $-0,8<[\mathrm{Fe} / \mathrm{H}]<+0,2$ tartományban is.
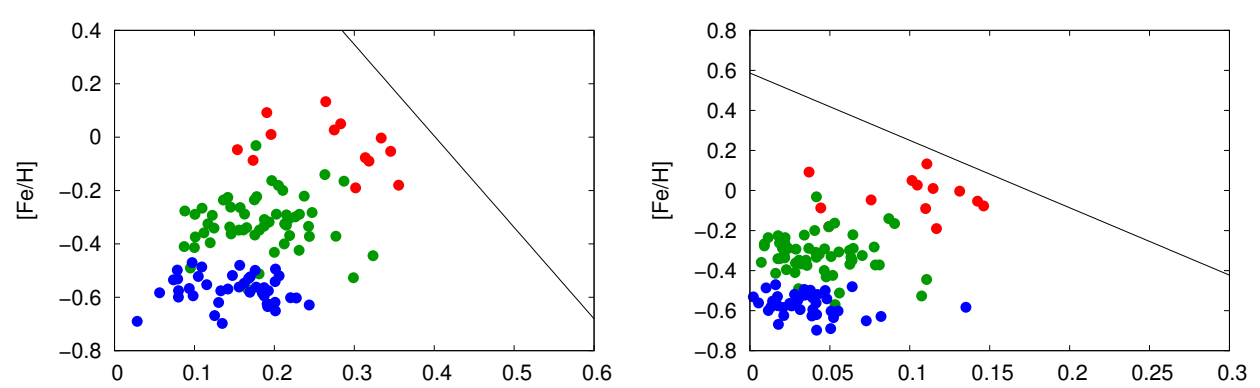

6.10. ábra. Az egyenes vß̊nal a Klagyivik et al. (2013) által męghatározott lineáris összefüggést mutatja az amplitudóarányok és a $[\mathrm{Fe} / \mathrm{H}]$ között, a pontok az általunk meghatározott beat cefeida adatokat jelölik (szimbólumok, színkódok megegyeznek a korábbiakkal). Látszik, hogy a reláció egyáltalán nem ad megfelelő becslést, kiváltképp az alacsonyabb fémtartalmak esetén.

Végeredményben, megvizsgáltuk a fénygörbék Fourier-paraméterei és a fémesség közötti összefüggést a Tejútrendszerben és a Magellán-felhőkben található kétmódusú cefeidák esetén. Azért esett a választásunk a beat cefeidákra, mert az ő esetükben megállapíthattunk egy jól definiált periódusarány-fémesség összefüggést, amely lehetővé tette számunkra, hogy megbízható $[\mathrm{Fe} / \mathrm{H}]$ értékeket határozunk meg a Magellán-felhők beat cefeidáira is, annak ellenére, hogy az esetükben hiányzik a nagy felbontású, nagy jel/zaj viszonyú spektroszkópiai adatokból megadott [Fe/H] 
érték. Végsô eredményként arra jutottunk, hogy a kombinált adatsorra való illesztés adja a legjobb eredményt, ezzel lehet a legjobb becslést adni a fotometriai fémességekre (6.8. ábra). A legjobban illeszkedő modell együtthatóit a 6.7. táblázat 5. oszlop tartalmazza. Arra a következtetésre jutottunk, hogy a beat cefeidák alapmódusának Fourier-paramétereit a 6.6. egyenlettel leírt lineáris modellel megillesztve nagyon jó becslést adhatunk a $[\mathrm{Fe} / \mathrm{H}]$ értékekre, még akkor is, ha jelentősen eltérô, pl. alacsonyabb fémességeink vannak. Bár ez az összefüggés pusztán empirikus, valószínúleg alkalmazható az egymódusú, alacsony fémtartalmú cefeidákra is. 


\section{7. fejezet}

\section{Összefoglalás}

Doktori munkám során célul tûztem ki az egyszerre két módusban pulzáló beat cefeidák fémtartalma és pulzációs tulajdonságai közti összefüggések tanulmányozását.

A galaktikus beat cefeidák kellően fényesek ahhoz, hogy nagy távcsővel nagy felbontású spektroszkópiai mérésekből közvetlen fémtartalmakat határozzunk meg. Ennek érdekében 2004-ben külföldi együttmúködő partnerünk közremúködésével méréseket végeztünk az Európai Déli Obszervatórium (ESO) chilei La Silla Obszervatóriumának 2,2 méteres távcsövére szerelt FEROS nevú nagy felbontású echelle-spekrográffal. A mérés eredményeként a 23 ismert beat cefeidából 17 olyan csillagról készítettünk spektrumokat, amelyekből 4-et korábban csak fotometriai módszerekkel vizsgáltak. Ezen mérések kiértékeléséből a beat cefeidák fémtartalmának és periódusarányának (korábban elméleti úton felismert) összefüggését igyekeztem pontosítani.

Nagy felbontású spektroszkópiai mérésekből meghatároztam 17 két módusban pulzáló galaktikus cefeida csillag fizikai paramétereit: effektív hômérsékletüket $\left(T_{\text {eff }}\right)$, felszíni gravitációs gyorsulásukat $(\log g)$, valamint a fémtartalmukat jellemző paramétert, a vas hidrogénhez képesti relatív gyakoriságát a Naphoz viszonyítva $\left([\mathrm{Fe} / \mathrm{H}]=\log \left(N_{\mathrm{Fe}} / N_{\mathrm{H}}\right)-\log \left(N_{\mathrm{Fe}} / N_{\mathrm{H}}\right)_{\odot}\right)$. A mintából 4 csillagot korábban csak fotometriai úton vizsgáltak, így ezekre a csillagokra elsôként határoztam meg közvetlenül spektroszkópiai fémtartalmat. Évekkel később az irodalomban újonnan megjelent fémességmérésekkel összevetve konzisztens skálán alapuló fémtartalmakat határoztam meg a vizsgált objektumokra, csökkentve ezzel az évtizedekkel korábbi méréseket erôsen befolyásoló szisztematikus eltéréseket.

Saját méréseim felhasználásával empirikus úton meghatároztam és pontosítottam a kétmódusú cefeidákra vonatkozó periódus-periódusarány-fémtartalom $\left(\log P-P_{1} / P_{0}-[\mathrm{Fe} / \mathrm{H}]\right)$ összefüggést. A reláció alacsonyabb fémességek felé történő extrapolálásával becslést tettem a Kis- és NagyMagellán-felhőkben található kétmódusú cefeidák fémtartalmára.

Irodalmi forrásokból összegyújtöttem az OGLE-III és OGLE-IV égboltfelméró programok fotometriai adatait a Nagy- és Kis-Magellán-felhőkben található kétmódusú cefeidákról. Ezekből kiválogattam azokat, amelyekben egyszerre az alapmódus és az elsô felharmonikus van gerjesztve. Az így kapott, összesen 98 csillagot tartalmazó mintában Fourier-analízis segítségével meghatároz- 
tam a fénygörbék alakját leíró amplitúdó- és fázisarányokat, valamint ugyanezen csillagok $[\mathrm{Fe} / \mathrm{H}]$ fémtartalmát az előző bekezdésben említett periódus-periódusarány-fémtartalom reláció segítségével.

Megállapítottam, hogy a kétmódusú cefeidák fémtartalmára leginkább érzékeny fotometriai paraméterek az adott módus amplitúdója, valamint az $R_{21}$ jelú amplitúdóarány (az első felhang és alapfrekvencia amplitúdóinak aránya). A fundamentális módus esetén kimutatható volt még a az elsô felhang és az alapfrekvencia fáziskülönbségei $\left(\varphi_{21}=\varphi_{2}-2 \varphi_{1}\right)$ közti korreláció is, ez azonban az első felharmonikus esetén (feltehetôen a kisebb jel/zaj viszony miatt) már nem volt szignifikáns.

Kimutattam, hogy az irodalomban korábban közölt relációk, amelyek a kizárólag fundamentális módusban pulzáló klasszikus cefeidák fémtartalma és Fourier-paraméterei közötti kapcsolatot írják le, nem használhatóak a Magellán-felhők rövid periódusú, kisebb amplitúdójú, alacsonyabb fémtartalmú kétmódusú cefeidáira. Helyettuik alternatív formulák használatát javasoltam, amelyek a vizsgált periódus-, amplitúdó- és fémességtartományon megbízhatóbb becsléseket tesznek lehetôvé. 


\section{8. fejezet}

\section{Summary}

Classical Cepheids are variable stars with essential importance from both astrophysical and cosmological point of view. These are massive giant- or supergiant stars that are located within the Instability Strip on the Hertzsprung-Russell diagram (HRD), and they exhibit stable, periodic light variation. This variability is due to radial pulsation excited and governed by the astrophysical process called kappa-mechanism.

The importance of pulsating stars, especially Cepheids, is given by the fact that we can reveal details on the internal structure and evolution of these stars by studying their oscillations. In cosmology they are mainly used as distance indicators, because the existence of the period-luminosity relation discovered 100 years ago make them useful for measuring distances on extragalactic (i.e. several megaparsecs) scale.

A small subgroup of Classical Cepheids contain stars that pulsate in two excited modes simultaneously. These are called double-mode, or beat Cepheids. Modeling these stars dates back to the $1990 \mathrm{~s}$, and it was recognized quite early that the period ratio $\left(P_{1} / P_{0}\right)$ depends strongly on other physical parameters like effective temperature, mass, luminosity and metallicity. Nevertheless, checking the theoretical predictions with observations was limited for a while, because, for example, having metallicity information for such stars requires high resolution, high signal-tonoise measurements that are feasible only with modern state-of-the-art instruments.

By the beginning of the 21st century only about two dozens of double-mode Cepheids were known within the Milky Way. On the other hand, hundreds of such stars were discovered in the Large- and Small Magellanic Cloud by the MACHO and OGLE sky surveys. Unfortunately, due to instrumental constraints, only the Milky Way (galactic-) Cepheids could be studied by highresolution spectroscopy to measure their metallicities directly. This is why new methods that attempt to derive physical parameters, like metallicity, solely from photometry gained more attention by now.

$\mathrm{My} \mathrm{PhD}$ dissertation focuses on studies related to these problems. The aim of my work is to reveal new details on the metallicity dependence of the pulsational properties of beat Cepheids.

Galactic beat Cepheids are so bright that their metallicities can be measured directly with high- 
resolution spectroscopy using big telescopes. In 2004, our foreign collaborators obtained such measurements for 17 beat Cepheids using the FEROS spectrograph attached to the $2.2 \mathrm{~m}$ telescope of the European Southern Observatory (ESO) at La Silla, Chile. 4 of our program stars have been studied before only with photometry. After reducing and analysing these data, my work focused on quantifying the correlation between the period ratio and metallicity that was revealed by theoretical studies earlier.

As an application of my results, I examined the double-mode Cepheids in the Large- and Small Magellanic Cloud attempting to correlate their metallicities with the Fourier parameters of their light curves. After collecting the existing photometric data from literature, First, I derived the Fourier-amplitude ratios and phase differences of the light curves that characterize the shape of the light curves. After that I looked for correlations between these Fourier parameters and the metallicities obtained from period ratios using the relation that I determined for the galactic beat Cepheids.

The new scientific results I found are summarized as follows.

Using new high-resolution spectroscopic data I derived the following physical parameters for 17 Galactic double-mode Cepheids: effective temperature $\left(T_{\mathrm{eff}}\right)$, surface gravity $(\log g)$ and metallicity expressed as the relative abundance of iron to hydrogen, $[\mathrm{Fe} / \mathrm{H}]=\log \left(N_{\mathrm{Fe}} / N_{\mathrm{H}}\right)-$ $\log \left(N_{\mathrm{Fe}} / N_{\mathrm{H}}\right)_{\odot}$. These were the first spectroscopic metallicities for 4 of the program stars that were studied before only photometrically. Years later, using more recent metallicity measurements collected from literature, I derived homogenized metallicities for all the program stars by bringing them onto a consistent metallicity scale reducing the systematic offsets plaguing the early metallicity measurements.

Based on the new spectroscopic data mentioned above I quantified and improved the period period ratio - metallicity $\left(\log P-P_{1} / P_{0}-[\mathrm{Fe} / \mathrm{H}]\right)$ relation that is valid for beat Cepheids pulsating in the fundamental mode and the first overtone simultaneously. By extrapolating the relation toward lower metallicities I estimated the metallicities of double-mode Cepheids in the Large- and Small Magellanic Clouds.

In order to study the possibilities for getting metallicity information solely from photometry, I collected photometric data for double-mode Cepheids in the Magellanic Clouds from the online databases of the OGLE-III and OGLE-IV surveys. I made a sample of 98 Cepheids simultaneously pulsating in the fundamental and first overtone modes. Then I characterized the shape of their light curves by computing the Fourier amplitude ratios and phase differences, and I determined their $[\mathrm{Fe} / \mathrm{H}]$ metallicities using the period - period ratio - metallicity relation mentioned above.

I found that the main amplitude and the $R_{21}$ amplitude ratio are the most sensitive photometric parameters to metallicity. For the fundamental mode there is also a correlation between metallicity and the phase difference between the main frequency and first harmonics $\left(\varphi_{21}=\varphi_{2}-2 \varphi_{1}\right)$, although it was not significant for the first overtone, probably because of the lower signal-to-noise of those data. 
I pointed out that the previously published relations describing the connection between the Fourier parameters and the metallicities of Classical Cepheids that pulsate only in the fundamental mode are not valid for the more metal-poor Magellanic Cloud beat Cepheids that have shorter periods and lower amplitudes. Instead, I established new relations that predict more reliable metallicities in this parameter regime. 


\section{9. fejezet}

\section{Köszönetnyilvánítás}

Az ember azt hinné, hogy a köszönetnyilvánítás a dolgozat megírásában a legkönnyebb rész, de amikor eljutottam idáig, akkor jöttem rá, hogy legalább annyira nehéz, mint a többi fejezet elkészítése.

Szeretném megköszönni a Szüleimnek az évek során tőlük kapott anyagi és lelki támogatást, ami nélkül most nem lehetnék csillagász. Hálás vagyok nekik azért, hogy akkor is hittek bennem és a csillagász mivoltomban, amikor én magam már megkérdőjeleztem ennek jogosságát.

Köszönöm Páromnak és Fiaimnak, hogy mellettem álltak és biztattak mindvégig, akkor is mikor nekem már lelkiismeret-furdalásom volt, mert úgy éreztem, túlzottan sok idôt kell nélkülem eltölteniük.

Mérhetetlen hálával és köszönettel tartozom Dr. Vinkó Józsefnek (tudományos főmunkatárs, MTA CSFK Konkoly Thege Miklós Csillagászati Intézet), aki a hosszú évek során tanárom, témavezetôm, kollégám volt. Köszönöm neki, hogy a tudományos munkámban mellettem állt, irányított, segített és végig hitte, hogy ez a dolgozat elkészül. Öröm volt vele együttmúkődni az évek során.

Szeretnék köszönetet mondani Dr. Szabados Lászlónak (tudományos tanácsadó, MTA CSFK Konkoly Thege Miklós Csillagászati Intézet) a kutatásaim során nyújtott sok-sok önzetlen segítségéért és a dolgozatom elkészítéséhez nyújtott sok hasznos tanácsáért, valamint türelméért. 


\section{Irodalomjegyzék}

[1] Alcock, C., Allsman, R. A., Axelrod, T. S., Bennett, D. P., Cook, K. H., Freeman, K. C., Griest, K., Marshall, S. L., Peterson, B. A., Pratt, M. R., Quinn, P. J., Reimann, J., Rodgers, A. W., Stubbs, C. W., Sutherland, W., Welch, D. L., 1995, The Astrophysical Journal, 109, 1654

[2] Andrievsky, S.M., Kovtjukh, V.V., Makarenko, E.N., \& Usenko, I.A., 1993, MNRAS, 265, 257

[3] Andrievsky, S.M., Kovtyukh, V.V., Usenko, I.A., Klochkova, V.G., \& Galazutdinov, G.A., $1994, A \& A S, 108,433$

[4] Andrievsky, S.M., Kovtyukh, V.V., Luck, R.E., Lépine, J.R.D., Bersier, D., et al. 2002, A\&A, 381,32

[5] Antipin, S.V., 1997, IBVS, 4485, 1

[6] Antipin, S.V., Gorynya, N.A., Sachkov, M.E., Samus, N.N., Berdnikov, L.N., Rastorgouev, A.S., \& Glushkova, E.V., 1999, IBVS, 4718, 1

[7] Asplund, M., Grevesse, N. \& Sauval, A.J., 2005, in Cosmic Abundances as Records of Stellar Evolution and Nucleosynthesis, ed. T. G. Barnes III \& F. N. Bash, ASP Conf. Ser., 336, 25

[8] Balona, L.A., 1985, Theory and Observations, IAU Coll. 82, 17, Edited by Madore, B.F. Cambridge Univ. Press, Cambridge

[9] Beaulieu, J.-P., Buchler, J.R., Marquette, J.-B., Hartman, J.D., Schwarzenberg-Czerny, A., 2006, The Astrophysical Journal, 653, 101

[10] Becker, S.A., 1998, The Variable Star Menagerie, ASP Conf. Ser., 135, 12, Edited by Bradley, P.A., Guzik, J.A.

[11] Beltrame, M. \& Poretti, E., 2002, A\& A, 386, L9

[12] Berdnikov L. N., 2006, http://www.sai.msu.ru/groups/cluster/CEP/PHE

[13] Berdnikov, L. N., 2008, VizieR Online Data Catalog, yCat, 2285, 0B

[14] Bersier, D., Burki, G., Mayor, M., \& Duquennoy, A., 1994, A\&AS, 108, 25 
[15] Buchler, J. R., 2008, The Astrophysical Journal, 680, 1412

[16] Buchler, J. R., \& Szabo, R., 2007, The Astrophysical Journal, 660, 723

[17] Chekhonadskikh, F. A., Kovtyukh, V. V., Belik, S. I., 2014, Odessa Astronomical Publications, 27/2, 111

[18] Cooper, W. A., Walker, E. N., 1994, "Csillagok távcsővégen" Gondolat, Budapest

[19] Cox A.N. (ed.), 2000, Allen's Astrophysical Quantities, 4th ed., AIP Press \& Springer

[20] Crawford, D.L., \& Barnes, J. V., 1970, The Astrophysical Journal, 75, 978

[21] D’Cruz, N.L., Morgan, S.M., \& Böhm-Vitense, E. 2000, AJ, 120, 990

[22] De Medeiros, J. R., Udry, S., Burki, G. \& Mayor, M., 2002, A\&A 395, 97

[23] Fry, A. M., \& Carney, B. W., 1997, The Astrophysical Journal, 113, 1073

[24] Gieren, W.P., Moffett, T.J., \& Barnes, T. G., III, 1999, The Astrophysical Journal, 512, 553

[25] Gorynya, N.A., Irsmambetova, T.R., Rastorgouev, A.S., \& Samus, N.N., 1992, SvAL, 18, 316

[26] Gorynya, N.A., Samus, N.N., Rastorguev, A.S., \& Sachkov, M.E., 1996, AstL, 22, 175

[27] Gorynya, N. A., Samus, N. N., Sachkov, M. E., Rastorguev, A. S., Glushkova, E. V., \& Antipin, S. V., 1998, AstL, 24, 815

[28] Hessellmann, N., 1985, Digitális jelfeldolgozás Múszaki Könyvkiadó, Budapest

[29] Ishida, T., 2017, Res. Astron. Astrophys., 17, 51

[30] Jurcsik, J., Kovács, G., 1996, A \& A, 312, 11

[31] Kaufer, A., Stahl, O., Tubbesing, S., Norregaard, P., Avila, G., Francqis, P., Pasquini, L., Pizzella, A., 1999, The Messenger, 95, 8

[32] Kiss, L.L., \& Vinkó, J., 2000, MNRAS, 314, 420

[33] Klagyivik, P., Szabados, L., Szing, A., et al., 2013, MNRAS, 434, 2418

[34] Kovács, G., 2000, $A$ \& A, 360, L1

[35] Kovács, G., Zsoldos, E., 1995, A \& A, 293, 57

[36] Kovtyukh, V. V. \& Andrievsky, S. M., 1999, A \& A, 351, 597

[37] Kovtyukh, V.V., Gorlova N.I., \& Hillen M., 2012, Odessa Astron. Pub., 25, 52 
[38] Kovtyukh, V. V., Wallerstein, G., \& Andrievsky, S. M., 2005, PASP, 117, 1173

[39] Kovtyukh V., Lemasle B., Cheknondadskikh F., Bono G., Matsunaga N., Yushchenko A., Anderson R.I., Belik S., da Silva R., Inno L., 2016, MNRAS, 460, 2077

[40] Lee, C.-H., Kodric, M., Seitz, S. et al., 2013, The Astrophysical Journal, 777, 35

[41] Lemasle, B., Groenewegen, M. A. T., Grebel, E. K., et al., 2017, A \& A, 608, A85

[42] Lemasle, B., François, P., Bono, G., Mottini, M., Primas, F., \& Romaniello, M., 2007, A \& A, 467, 283

[43] Luck, R. E., Lambert, D. L., 2011, The Astrophysical Journal, 142, 136

[44] Luck, R. E., Moffett, T. J., Barnes, T. G., III, \& Gieren, W. P. 1998, AJ, 115, 605

[45] Marik M.(szerk.), 1989, Csillagászat, Akadémiai Kiadó, Budapest

[46] Marquette, J. B., Beaulieu, J. P., Buchler, J. R. et al., 2009, A \& A, 495, 249

[47] Miller, A. A., Bloom, J. S., Richards, J. W., et al., 2015, The Astrophysical Journal, 798, 122.

[48] Morgan, S. M. \& Welch, D. L., 1997, The Astrophysical Journal, 114, 1183

[49] Nardetto, N., Mourard, D., Kervella, P., Mathias, Ph., Mérand, A. \& Bersier, D., 2006, A \& A, 453, 309

[50] Oke, J.B., 1974, ApJS, 27, 21

[51] Paczynski, B., 1986, The Astrophysical Journal, 304, 1

[52] Pardo, I. \& Poretti, E., 1997, A \& A, 324, 121

[53] Petersen, J. O., 1973, $A \& A, 27,89$

[54] Petersen, J.O., \& Takeuti, M., 2001, in Takeuti, M., \& Sasselov, D.D., eds, Stellar pulsation - nonlinear studies (ASSL 257), Dordrecht: Kluwer Academic Publ., 1

[55] Petterson, O. K. L., Cottrell P. L., \& Albrow M. D., 2004, MNRAS, 350, 95

[56] Pojmański, G., 2009, The Variable Universe: A Celebration of Bohdan Paczyński, ASP Conf.Ser., 403, Astron. Soc. Pac., San Francisco, 52.

[57] Poleski, R., 2013, The Astrophysical Journal, 778, 2

[2004] Poretti, E. \& Beltrame M., 2004, Comm. in Asteroseismology, 145, 55

[59] Rainer, M., 2003, Laurea Thesis, Universita di Milano 
[60] Simon, N. R., Lee, A. S., 1981, The Astrophysical Journal, 248, 291

[61] Soszynski, I., Poleski, R., Udalski, A.,et al., 2008, Acta Astronomica, 58, 163.

[62] Soszynski, I., Poleski, R., Udalski, A., et al., 2010, Acta Astronomica, 60, 17.

[63] Soszyński, I., Udalski, A., Szymanski, M. K., et al., 2015, Acta Astronomica, 65, 329

[64] Soszynski, I., Udalski, A., Szymanski, M. K., et al., 2017, Acta Astronomica, 67, 103.

[65] Stobie, R. S. \& Balona, L. A., 1979, MNRAS, 188, 595

[66] Szabados, L., Klagyivik, P., 2012, Ap \& SS, 341, 99.

[67] Udalski, A., 2003, Acta Astronomica, 53, 291)

[68] Udalski, A., Kubiak, M., Szymański, M. K., 1997, Acta Astronomica, 47, 319

[69] Udalski, A., Soszyński, I., Szymanski, M. K., et al., 2015, Acta Astronomica, 65, 341

[70] Takeda, Y., Kawanomoto, S. \& Ando, H., 1997, PASJ, 49, 493

[71] Welch, D. L., Alcock, C., Allasman, R. A., Alves, D. R., Axelrod, T. S., et al., 1996, Variable Stars and the Astrophysical Returns of Microlensing Surveys, 205, Edited by Ferlet, R., Maillard, J.P. and Raban, B.

[72] Wielgórski, P., Pietrzyński, G., Gieren, W., et al., 2017, The Astrophysical Journal, 842, 116.

[73] Wils P., Henden, A. A., Kleidis, S., Schmidt, E. G., Welch, D. L., 2010, MNRAS, 402, 1156 [2004] Wils, P. \& Otero, S. A. 2004, IBVS, 5501, 1

[75] Zsoldos E., 1995, Astrophysical Applications of Stellar Pulsation, ASP Conf. Ser. Vol., 83, eds. Stobie R. S., Whitelock P. A., Astron. Soc. Pac., San Francisco, p. 351. 


\section{0. fejezet}

\section{Függelék}

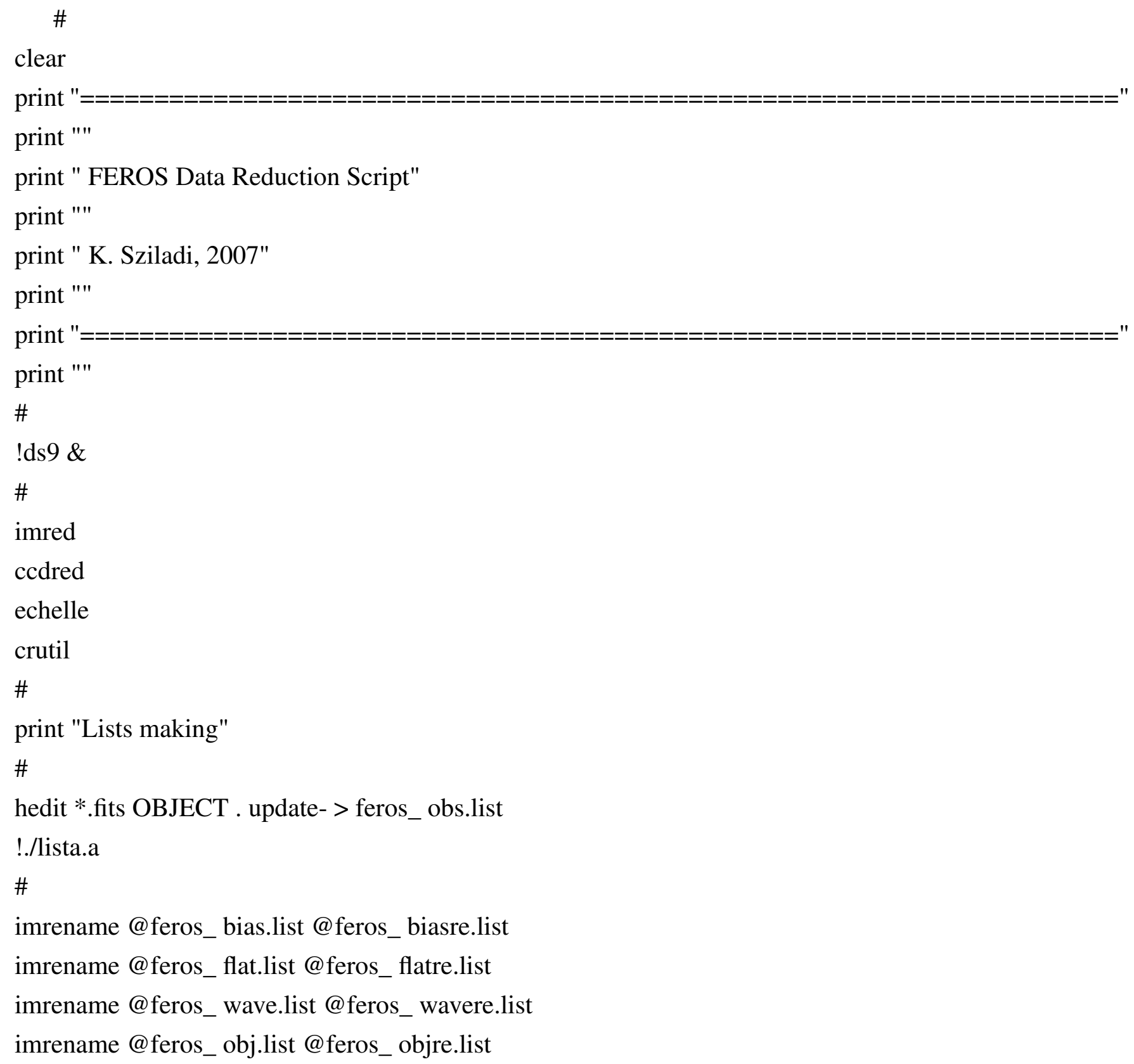




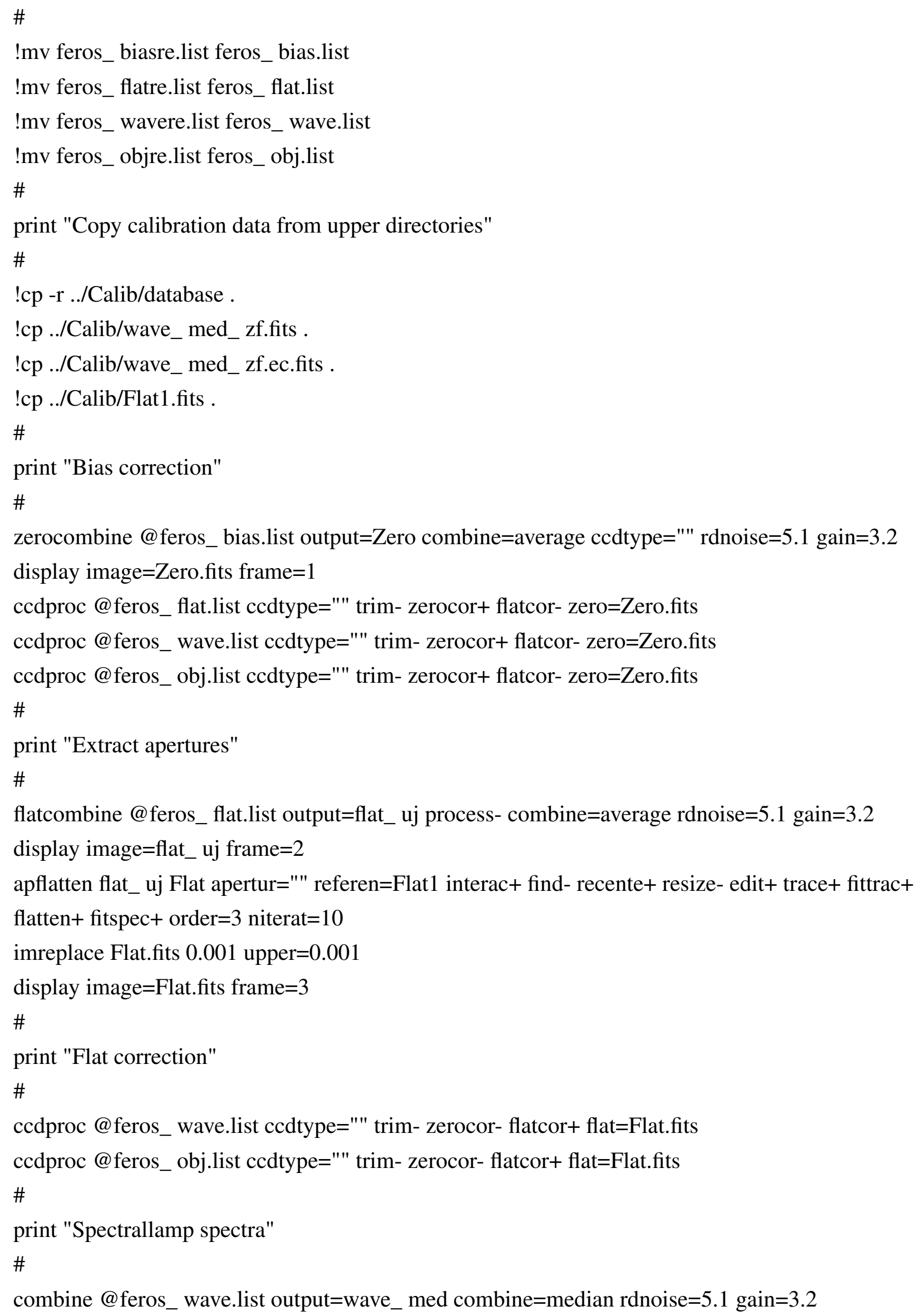




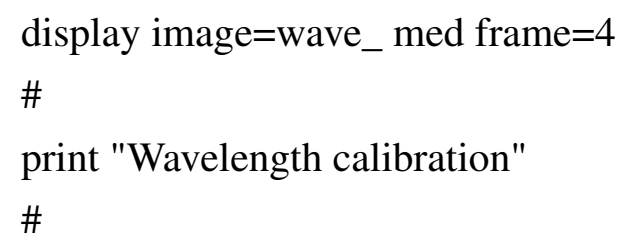


scopy(s2//".0023",s2//"_ c.0023",w1=4745,w2=INDEF,format="multispec",renumber-) scopy(s2//".0024",s2//"_ c.0024",w1=4650,w2=INDEF,format="multispec",renumber-) scopy(s2//".0025",s2//"_ c.0025",w1=4555,w2=INDEF,format="multispec",renumber-) scopy(s2//".0026",s2//"_ c.0026",w1=4460,w2=INDEF,format="multispec",renumber-) scopy(s2//".0027",s2//"_ c.0027",w1=4375,w2=INDEF,format="multispec",renumber-) scopy(s2//".0028",s2//"_ c.0028",w1=4290,w2=INDEF,format="multispec",renumber-) scopy(s2//".0029",s2//"_ c.0029",w1=4215,w2=INDEF,format="multispec",renumber-) scopy(s2//".0030",s2//"_ c.0030",w1=4140,w2=INDEF,format="multispec",renumber-) scopy(s2//".0031",s2//"_c.0031",w1=4070,w2=INDEF,format="multispec",renumber-) scopy(s2//".0032",s2//"_c.0032",w1=4000,w2=4114,format="multispec",renumber-) scopy(s2//".0033",s2//"_ c.0033",w1=3940,w2=INDEF,format="multispec",renumber-) scopy(s2//".0034",s2//"_ c.0034",w1=3870,w2=INDEF,format="multispec",renumber-) scopy(s2//".0035",s2//"_ c.0035",w1=3810,w2=INDEF,format="multispec",renumber-) \#

continuum(s2//"_c.0001",s2//"_k.0001",replace-,type="fit",low_rej=2,high_rej=0,niterat=2) continuum(s2//"_c.0002",s2//"_k.0002",replace-,type="fit",low_rej=2,high_ rej=0,niterat=2) continuum(s2//"_c.0003",s2//"_k.0003",replace-,type="fit",low_rej=2,high_rej=0,niterat=2) continuum(s2//"_c.0004",s2//"_k.0004",replace-,type="fit",low_rej=2,high_rej=0,niterat=2) continuum(s2//"_c.0005",s2//"_ k.0005",replace-,type="fit",low_rej=2,high_rej=0,niterat=2) continuum(s2//"_c.0006",s2//"_k.0006",replace-,type="fit",low_rej=2,high_rej=0,niterat=2) continuum(s2//"_c.0007",s2//"_k.0007",replace-,type="fit",low_rej=2,high_rej=0,niterat=2) continuum(s2//"_c.0008",s2//"_k.0008",replace-,type="fit",low_rej=2,high_rej=0,niterat=2) continuum(s2//"_c.0009",s2//"_k.0009",replace-,type="fit",low_rej=2,high_rej=0,niterat=2) continuum(s2//"_c.0010",s2//"_k.0010",replace-,type="fit",low_rej=2,high_ rej=0,niterat=2) continuum(s2//"_c.0011",s2//"_k.0011",replace-,type="fit",low_rej=2,high_rej=0,niterat=2) continuum(s2//"_c.0012",s2//"_k.0012",replace-,type="fit",low_rej=2,high_rej=0,niterat=2) continuum(s2//"_c.0013",s2//"_k.0013",replace-,type="fit",low_rej=2,high_rej=0,niterat=2) continuum(s2//"_c.0014",s2//"_k.0014",replace-,type="fit",low_rej=2,high_rej=0,niterat=2) continuum(s2//"_c.0015",s2//"_k.0015",replace-,type="fit",low_rej=2,high_rej=0,niterat=2) continuum(s2//"_c.0016",s2//"_ k.0016",replace-,type="fit",low_rej=2,high_rej=0,niterat=2) continuum(s2//"_c.0017",s2//"_k.0017",replace-,type="fit",low_rej=2,high_rej=0,niterat=2) continuum(s2//"_c.0018",s2//"_k.0018",replace-,type="fit",low_rej=2,high_rej=0,niterat=2) continuum(s2//"_c.0019",s2//"_k.0019",replace-,type="fit",low_rej=2,high_rej=0,niterat=2) continuum(s2//"_c.0020",s2//"_k.0020",replace-,type="fit",low_rej=2,high_rej=0,niterat=2) continuum(s2//"_c.0021",s2//"_k.0021",replace-,type="fit",low_rej=2,high_rej=0,niterat=2) continuum(s2//"_c.0022",s2//"_k.0022",replace-,type="fit",low_rej=2,high_rej=0,niterat=2) continuum(s2//"_c.0023",s2//"_k.0023",replace-,type="fit",low_rej=2,high_rej=0,niterat=2) continuum(s2//"_c.0024",s2//"_k.0024",replace-,type="fit",low_rej=2,high_rej=0,niterat=2) 


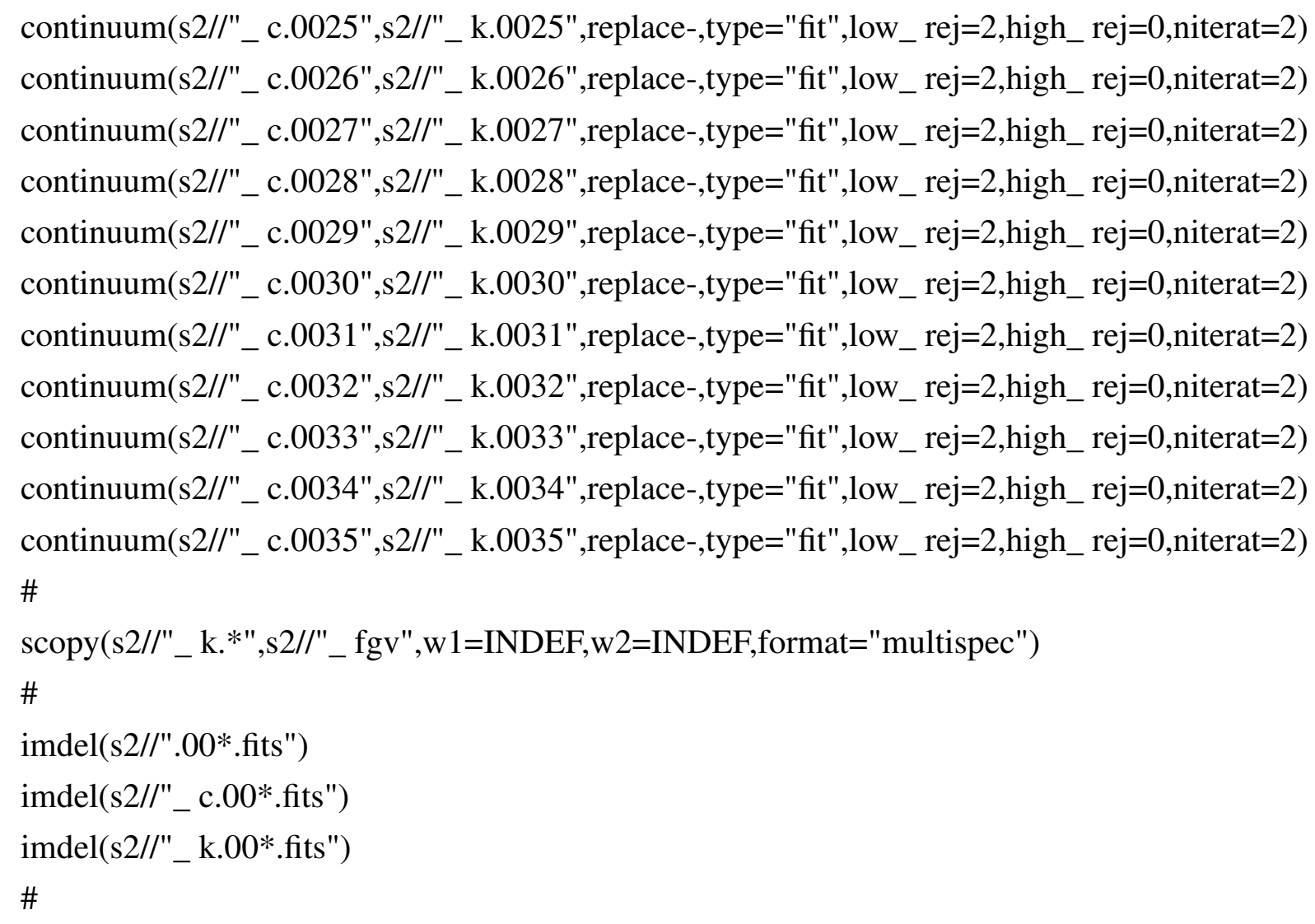


scopy(s1//".0013",s1//"_ c.0013",w1=6005,w2=INDEF,format="multispec",renumber-) scopy(s1//".0014",s1//"_ c.0014",w1=5845,w2=INDEF,format="multispec",renumber-) scopy(s1//".0015",s1//"_ c.0015",w1=5695,w2=INDEF,format="multispec",renumber-) scopy(s1//".0016",s1//"_ c.0016",w1=5555,w2=INDEF,format="multispec",renumber-) scopy(s1//".0017",s1//"_c.0017",w1=INDEF,w2=INDEF,format="multispec",renumber-) scopy(s1//".0018",s1//"_ c.0018",w1=INDEF,w2=INDEF,format="multispec",renumber-) scopy(s1//".0019",s1//"_ c.0019",w1=5180,w2=INDEF,format="multispec",renumber-) scopy(s1//".0020",s1//"_c.0020",w1=5065,w2=INDEF,format="multispec",renumber-) scopy(s1//".0021",s1//"_ c.0021",w1=4955,w2=INDEF,format="multispec",renumber-) scopy(s1//".0022",s1//"_ c.0022",w1=4850,w2=INDEF,format="multispec",renumber-) scopy(s1//".0023",s1//"_ c.0023",w1=4745,w2=INDEF,format="multispec",renumber-) scopy(s1//".0024",s1//"_ c.0024",w1=4650,w2=INDEF,format="multispec",renumber-) scopy(s1//".0025",s1//"_ c.0025",w1=4555,w2=INDEF,format="multispec",renumber-) scopy(s1//".0026",s1//"_ c.0026",w1=4460,w2=INDEF,format="multispec",renumber-) scopy(s1//".0027",s1//"_ c.0027",w1=4375,w2=INDEF,format="multispec",renumber-) scopy(s1//".0028",s1//"_ c.0028",w1=4290,w2=INDEF,format="multispec",renumber-) scopy(s1//".0029",s1//"_ c.0029",w1=4215,w2=INDEF,format="multispec",renumber-) scopy(s1//".0030",s1//"_ c.0030",w1=4140,w2=INDEF,format="multispec",renumber-) scopy(s1//".0031",s1//"_ c.0031",w1=4070,w2=INDEF,format="multispec",renumber-) scopy (s1//".0032",s1//"_c.0032",w1=4000,w2=4114,format="multispec",renumber-) scopy(s1//".0033",s1//"_ c.0033",w1=3940,w2=INDEF,format="multispec",renumber-) scopy(s1//".0034",s1//"_ c.0034",w1=3870,w2=INDEF,format="multispec",renumber-) scopy(s1//".0035",s1//"_ c.0035",w1=3810,w2=INDEF,format="multispec",renumber-) \#

continuum(s1//"_c.0001",s1//"_k.0001",replace+,type="data",low_rej=0,high_rej=2.5,niterat=2,grow=4) continuum(s1//"_c.0002",s1//"_k.0002",replace+,type="data",low_rej=0,high_rej=2.5,niterat=2,grow=4) continuum(s1//"_c.0003",s1//"_k.0003",replace+,type="data",low_rej=0,high_rej=2.5,niterat=2,grow=4) continuum(s1//"_c.0004",s1//"_k.0004",replace+,type="data",low_rej=0,high_rej=2.5,niterat=2,grow=4) continuum(s1//"_c.0005",s1//"_k.0005",replace+,type="data",low_rej=0,high_rej=2.5,niterat=2,grow=4) continuum(s1//"_c.0006",s1//"_k.0006",replace+,type="data",low_rej=0,high_rej=2.5,niterat=2,grow=4) continuum(s1//"_c.0007",s1//"_k.0007",replace+,type="data",low_rej=0,high_rej=2.5,niterat=2,grow=4) continuum(s1//"_c.0008",s1//"_k.0008",replace+,type="data",low_rej=0,high_rej=2.5,niterat=2,grow=4) continuum(s1//"_c.0009",s1//"_k.0009",replace+,type="data",low_rej=0,high_rej=2.5,niterat=2,grow=4) continuum(s1//"_c.0010",s1//"_k.0010",replace+,type="data",low_rej=0,high_rej=2.5,niterat=2,grow=4) continuum(s1//"_c.0011",s1//"_k.0011",replace+,type="data",low_rej=0,high_rej=2.5,niterat=2,grow=4) continuum(s1//"_c.0012",s1//"_k.0012",replace+,type="data",low_rej=0,high_rej=2.5,niterat=2,grow=4) continuum(s1//"_c.0013",s1//"_k.0013",replace+,type="data",low_rej=0,high_rej=2.5,niterat=2,grow=4) continuum(s1//"_c.0014",s1//"_k.0014",replace+,type="data",low_rej=0,high_rej=2.5,niterat=2,grow=4) 
continuum(s1//"_c.0015",s1//"_k.0015",replace+,type="data",low_rej=0,high_rej=2.5,niterat=2,grow=4) continuum(s1//"_c.0016",s1//"_k.0016",replace+,type="data",low_rej=0,high_rej=2.5,niterat=2,grow=4) continuum(s1//"_c.0017",s1//"_k.0017",replace+,type="data",low_rej=0,high_rej=2.5,niterat=2,grow=4) continuum(s1//"_c.0018",s1//"_k.0018",replace+,type="data",low_rej=0,high_rej=2.5,niterat=2,grow=4) continuum(s1//"_c.0019",s1//"_k.0019",replace+,type="data",low_rej=0,high_rej=2.5, niterat=2,grow=4) continuum(s1//"_c.0020",s1//"_k.0020",replace+,type="data",low_rej=0,high_rej=2.5,niterat=2,grow=4) continuum(s1//"_c.0021",s1//"_k.0021",replace+,type="data",low_rej=0,high_rej=2.5,niterat=2,grow=4) continuum(s1//"_c.0022",s1//"_k.0022",replace+,type="data",low_rej=0,high_rej=2.5,niterat=2,grow=4) continuum(s1//"_c.0023",s1//"_k.0023",replace+,type="data",low_rej=0,high_rej=2.5,niterat=2,grow=4) continuum(s1//"_c.0024",s1//"_k.0024",replace+,type="data",low_rej=0,high_rej=2.5,niterat=2,grow=4) continuum(s1//"_c.0025",s1//"_k.0025",replace+,type="data",low_rej=0,high_rej=2.5,niterat=2,grow=4) continuum(s1//"_c.0026",s1//"_k.0026",replace+,type="data",low_rej=0,high_rej=2.5,niterat=2,grow=4) continuum(s1//"_c.0027",s1//"_k.0027",replace+,type="data",low_rej=0,high_rej=2.5,niterat=2,grow=4) continuum(s1//"_c.0028",s1//"_k.0028",replace+,type="data",low_rej=0,high_rej=2.5,niterat=2,grow=4) continuum(s1//"_c.0029",s1//"_k.0029",replace+,type="data",low_rej=0,high_rej=2.5,niterat=2,grow=4) continuum(s1//"_c.0030",s1//"_k.0030",replace+,type="data",low_rej=0,high_rej=2.5,niterat=2,grow=4) continuum(s1//"_c.0031",s1//"_k.0031",replace+,type="data",low_rej=0,high_rej=2.5,niterat=2,grow=4) continuum(s1//"_c.0032",s1//"_k.0032",replace+,type="data",low_rej=0,high_rej=2.5,niterat=2,grow=4) continuum(s1//"_c.0033",s1//"_k.0033",replace+,type="data",low_rej=0,high_rej=2.5,niterat=2,grow=4) continuum(s1//"_c.0034",s1//"_k.0034",replace+,type="data",low_rej=0,high_rej=2.5,niterat=2,grow=4) continuum(s1//"_c.0035",s1//"_k.0035",replace+,type="data",low_rej=0,high_rej=2.5,niterat=2,grow=4) \#

scopy(s1//"_k.*",s1//"_ec",w1=INDEF,w2=INDEF,format="multispec") imarith s1//"_ec" / Blaze_fgv.fits s1//"_ec_b"

\#

imdel(s1//".00*.fits")

imdel(s1//"_c.00*.fits")

imdel(s1//"_k.00*.fits")

\}

\#

print "Continuum normalization"

!ls obj*_ec_b.fits> feros_obj_nor1.list

!sed s/_ec./nor./ feros_obj_nor1.list $>$ feros_nor.list

continuum @feros_obj_nor1.list @ feros_nor.list "YES" type=ratio replace- overrid+ interac+ order $=3$

functio=spline3 low_rej=2 high_rej=0 niterat $=10$

\# !sed s/nor./norc./ feros_nor.list $>$ feros_norc.list

\# continuum @ feros_nor.list @ feros_norc.list "YES" type=ratio replace+ interac- order=1 


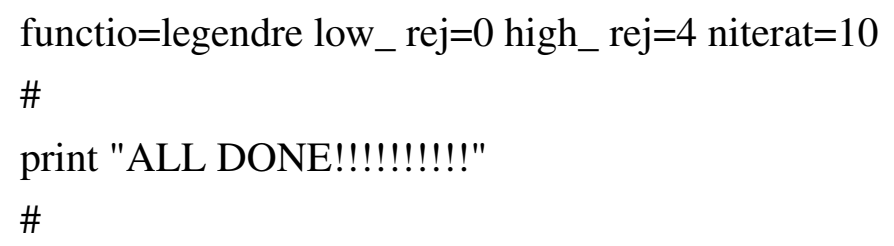

